\title{
MASTER
}

\section{Characterization and Recognition of Intraflow Structures, Grande Ronde Basalt}

P. E. Long

September 1978

Prepared for the United States

Department of Energy

Under Contract EY-77-C-06-1030

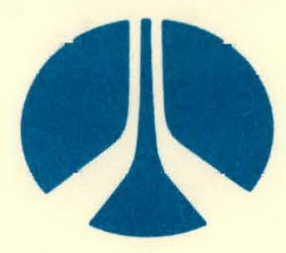

Rockwell International

Rockwell Hanford Operations

Energy Systems Group

Richland, WA 99352 


\section{DISCLAIMER}

This report was prepared as an account of work sponsored by an agency of the United States Government. Neither the United States Government nor any agency Thereof, nor any of their employees, makes any warranty, express or implied, or assumes any legal liability or responsibility for the accuracy, completeness, or usefulness of any information, apparatus, product, or process disclosed, or represents that its use would not infringe privately owned rights. Reference herein to any specific commercial product, process, or service by trade name, trademark, manufacturer, or otherwise does not necessarily constitute or imply its endorsement, recommendation, or favoring by the United States Government or any agency thereof. The views and opinions of authors expressed herein do not necessarily state or reflect those of the United States Government or any agency thereof. 


\section{DISCLAIMER}

Portions of this document may be illegible in electronic image products. Images are produced from the best available original document. 


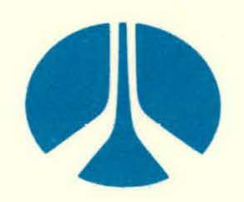

\title{
Rockwell International
}

\author{
Rockwell Hanford Operations \\ Energy Systems Group \\ Richland, WA 99352
}

\author{
PREPARED FOR THE UNITED STATES DEPARTMENT OF ENERGY \\ UNDER CONTRACT EY-77-C-06-1030
}

\section{PRELIMINARY REPORT}

This Report contains information of a prelımınary nature. It is subject to revision or correction and therefore does not represent a final Report. It was prepared primarily for internal use within The Rockwell Hanford Operations. Any expressed views and opinions are those of the Author and not necessarily of the Company.

NOTICE

This Report was prepared as an account of work sponsored by the United States Government. Neither the United States nor the United States Department of Energy, nor any of their Employees, nor any of their Contractors, Subcontractors, or their Employees, makes any warranty, express or implied, or assumes any legal liability or responsibility for the accuracy, completeness, ur usefulıess of any information, apparatus, product or process disclosed, or represents that its use would not infringe privately owned rights. 
CHARACTERIZATION AND RECOGNITION OF INTRAFLOW STRUCTURES, GRANDE RONDE BASALT

\author{
P. E. Long. \\ Basait Geosciences Unit \\ Research Department
}

This repor was poTICE

sponsored by the Uniepared as an accounc of work

United Sutes norited States Govermnzert. Neither the

Energy, nor any of United States Department of

ecntrectors, sub of their employecs, nor any of their

any warranty, expractors, or their employees, makes

lisbility or respontess or ismplied, or assumes any legal

or usefulass of any inf for the accuracy, completeness

process uis of any in formation, apparalus, product or

infringe privately or represents that its use would not

infringe privately owned rights.

for

Basalt Waste Isolation Program

$\zeta$

September 1978

DERTRIBUTION OF TEIL L.........

Rockwell Internationa?

Rockwell Hanford Uperations

Energy Systems Group

Richland, Washington 99352 


\section{A B S T R A C T}

This report documents an investigation of intraflow stmuctures in Grande Ronde Basalt carried out as part of a feasibility study for long-term storage of nuclear waste at depth in the Pasco Basin. The purpose of this investigation has been to characterize intraflow structures in Grande Ronde basalts and develop techniques for their subsurface recognition. Three general types of intraflow stmuctures were found at Sentinel Gap:

1. Flows with stubby, irregular columns that lack a well-developed entablature;

2. Flows consisting of multiple tiers of largely entablature-type columns;

3. Flows with a well-developed colonnade and entablature showing a sharp break between the two.

Certain features occur localiy in all three types of intraflow stmuctures. These include variations in fracture morphology, primary platey fracture zones, piliow-palagonite zones, and tectonically induced zones of closely spaced fractures.

Fractures in each of the three types of flows were logged both at the surface and in core from Core Hole DH-5, and petrographic textures of basalt sampled from surface exposures were examined.

The textures of the basalt correlate with the intraflow strucliures and provide a technique for identifying flows as to their general type of intraflow stmucture, locating intermal contacts between intraflow structures and possibly estimating fracture densily within flows.

Fracture logging, on the other hand, does not accurately. delimit intraflow structures. 
TABLE OF CONTENTS

Page

INTRODUCTION

PURPOSE AND SCOPE OF THE STUDY $\quad 7$

$\begin{array}{ll}\text { PREVIOUS WORK } & 10\end{array}$

METHODS 11

OBSERVATION OF GENERAL INTRAFLOW STRUCTURES

MEASUREMENT OF FRACTURES IN DRILL CORE 11

MEASUREMENT OF SURFACE FRACTURES 12

OBSERVATIONS OF BASALT TEXTURES 12

RESULTS 12

TYPES OF INTRAFLOW STRUCTURES AT SENTINEL GAP 12

DETAILS OF FRACTURE MORPHOLOGY 17

PLATY FRACTURE ZONES 28

BASAL PILLOW PALAGONITE $\quad 28$

RESULTS FROM DRILL CORE MEASUREMENTS . $\quad 35$

RESULTS FROM SURFACE MEASUREMENTS $\quad 49$

CORRELATION OF BASALT TEXTURES WITH INTRAFLOW STRUCTURES

DISCUSSION OF RESULTS $\quad 65$

CONCLUSIONS AND RECOMMENDATIONS $\quad 67$

$\begin{array}{ll}\text { ACKNOWLEDGMENTS } & 68\end{array}$

BIBLIOGRAPHY $\cdot 68$

DISTRIBUTION 69

APPENDIX-PROCEDURE FOR COLLECTION OF FRACTURE DATA FROM SURFACE OUTCROPS

LIST OF FIGURES

FIGURE 1-A LOCATIONS OF DH-5, PASCO BASIN AND SCHWANA, AND SENTINEL BLUFFS STRATIGRAPHIC SECTIONS

FIGURE 1-B PASCO BASIN STRATIGRAPHIC NOMENCLATURE 9

$\begin{array}{lll}\text { FIGURE } 2 & \text { VESICLE CYLINDERS IN FLOW J, SENTINEL GAP } & 14\end{array}$

FIGIIRF $3 \quad$ ROCKY COULEE FLOW, SENTINEL GAP - 15

$\begin{array}{lll}\text { FIGURE } 4 & \text { PLATY FRACTURE ZONE IN THE ROCKY COULEE FLOW } & 16\end{array}$

FIGURE 5 SHARP CONTACT BETWEEN ENTABLATURE AND

COLONNADE, FLOW E, SENTINEL GAP 
FIGURE 6 INVERTED FAN ARRANGEMENT OF ENTABLATURE $\begin{array}{ll}\text { COLUMNS IN FLOW E } & 19\end{array}$

Page

FIGURE 7-A PINCH-AND-SWELL IN COLONNADE COLUMNS, FLOW E

FIGURE 7-B DETAIL OF REGULAR PINCH-AND-SWELL FEATURES IN FLOW E

FIGURE 8 A BALL-AND-SOCKET JOINT IN FLOW E

FIGURE 9-A CHISEL MARKS IN THE LOWER PART OF THE ROCKY COULEE FLOW

FIGURE 9-B CHISEL MARKS IN THE LOWER PART OF THE ROCKY COULEE FLOW

FIGURE 10 CHISEL MARKS ON A JOINT SURFACE OF FLOW E IN THE ROCKY COULEE FLOW

FIGURE 11 DIFFERENCES IN SURFACE ROUGHNESS ON A FRACTURE SURFACE IN THE ENTABLATURE OF FLOW E

FIGURE 12 KNOBBY FRACTURE SURFACE ON PLATY ZONE

FRACTURE IN THE ROCKY COULEE FLOW

FIGURE 13 - CLOSELY SPACED, SUBPARALLEL FRACTURES IN A PLATY ZONE, FLOW E

FIGURE 14-A TECTONIC FRACTURES AT SENTINEL GAP . . . . 31

FIGURE 14-B TECTONIC FRACTURES AT SENTINEL GAP : 32

FIGURE 14-C TECTONIC FRACTURES AT SENTINEL GAP 33

FIGURE 15 THIN PILLOWED ZONES AT THE BASE OF FLOW J. . 34

FIGURE 16-A POSITION IN FLOW PLOTTED AGAINST AVERAGE NUMBER OF FRACTURES PER FOOT FOR THE MUSEUM FLOW FROM DH-5 36

FIGURE 16-B POSITION IN FLOW PLOTTED AGAINST AVERAGE NUMBER OF FRACTURES PER FOOT FOR THE ROCKY COULEE FLOW FROM DH-5

FIGURE 16-C POSITION IN FLOW PLOTTED AGAINST AVERAGE NUMBER OF FRACTURES PER FOOT FOR FLOW E FROM DH-5

FIGURE 17-A POSITION IN FLOW PLOTTED AGAINST AVERAGE NUMBER OF FRACTURES PER FOOT >0.2-MILLIMETER THICKNESS FOR THE MUSEUM FLOW FROM DH-5

FIGURE 17-B POSITION IN FLOW PLOTTED AGAINST AVERAGE NUMBER OF FRACTURES PER FOOT >0.2-MILLIMETER THICKNESS FOR THE ROCKY COULEE FLOW FROM DH-5 
Page

FIGURE 17-C POSITION IN FLOW PLOTTED AGAINST AVERAGE NUMBER OF FRACTURES PER FOOT >0.2-MILLMETER THICKNESS

FOR FLOW E FROM DH-5

FIGURE 18-A POSITION IN FLOW PLOTTED AGAINST PERCENTAGE

FRACTURES WITH GREATER THAN 60-DEGREE DIP FOR THE MUSEUM FLOW FROM DH-5

FIGURE 18-B POSITION IN FLOW PLOTTED AGAINST PERCENTAGE

FRACTURES WITH GREATER THAN 60-DEGREE DIP FOR

THE ROCKY COULEE FLOW FROM DH-5

FIGURE 18-C POSITION IN FLOW PLOTTED AGAINST PERCENTAGE

FRACTURES WITH GREATER THAN 60-DEGREE DIP FOR

FLOW E FROM DH-5

FIGURE 19-A POSITION IN FLOW PLOTTED AGAINST MAXIMUM

FRACTURE LENGTH FOR THE MUSEUM FLOW FROM DH-5

FIGUREE 19-B POSITION IN FLOW PLOTTED AGAINST MAXIMUM FRACTURE LENGTH FOR THE ROCKY COULEE FLOW FROM DH-5

FIGURE 19-C POSITION IN FLOW PLOTTED AGAINST MAXIMUM

FRACTURE LENGTH FOR FLOW E FROM DH-5

FIGURE 20-A POSITION IN FLOW PLOTTED AGAINST AVERAGE NUMBER OF FRACTURES PER FOOT FOR THE MUSEUM FLOW FROM SURFACE EXPOSURES AT SENTINEL GAP

FIGURE 20-B POSITION IN FLOW PLOTTED AGAINST AVERAGE NUMBER OF FRACTURES PER FOOT FOR THE ROCKY COULEE FLOW FROM SURFACE EXPOSURES AT SENTINEL GAP

FIGURE 20-C POSITION IN FLOW PLOTTED AGAINST AVERAGE NUMBER OF FRACTURES PER FOOT FOR FLOW E FROM SURFACE EXPOSURES AT SENTINEL GAP

FIGURE 21-A POSITION IN FLOW PLOTTED AGAINST PERCENTAGE OF FRACTURES WITH GREATER THAN A 60-DEGREE DIP FOR THE MUSEUM FLOW FROM SURFACE EXPOSURES AT SENTINEL GAP

FIGURE 21-B POSITION IN FLOW PLOTTED AGAINST PERCENTAGE OF FRACTURES WITH GREATER THAN A 60-DEGREE DIP FOR THE ROCKY COULEE FLOW FROM SURFACE EXPOSURES AT SENTINEL GAP

FIGURE 21-C POSITION IN FLOW PLOTTED AGAINST PERCENTAGE OF FRACTURES WITH GREATER THAN A 60-DEGREE DIP FOR FLOW E FROM SURFACE EXPOSURES AT SENTINEL GAP

FIGURE 22-A PHOTOMICROGRAPHS COMPARING TEXTURES OF ENTABLATURE AND COLONNADDE OF THE UMTANUM FLOW AT UMTANUM RIDGE ENTABLATURE, REFLECTED LIGHT 
Page

FIGURE 22-B PHOTOMICROGRAPHS COMPARING TEXTURES OF ENTABLATURE AND COLONNADE. OF THE UMTANUM FLOW AT UMTANUM RIDGE COLONNADE, REFLECTED LIGHT

FIGURE 22-C PHOTOMICROGRAPHS COMPARING TEXTURES OF ENTABLATURE AND COLONNADE OF THE UMTANUM FLOW AT UMTANUM RIDGE ENTABLATURE, PLANE POLARIZED TRANSMITTED LIGHT

FIGURE 22-D PHOTOMICROGRAPHS COMPARING TEXTURES OF ENTABLATURE AND. COLONNADE OF THE UMTANUM FLOW AT UMTANUM RIDGE COLONNADE, PLANE POLARIZED TRANSMITTED LIGHT

FIGURE 22-E PHOTOMICROGRAPHS COMPARING TEXTURES OF ENTABLATURE AND COLONNADE OF THE UMTANUM FLOW AT UMTANUM RIDGE ENTABLATURE, CROSSED NICOLS

FIGURE 22-F PHOTOMICROGRAPHS COMPARING TEXTURES OF ENTABLATURE AND COLONNADE OF THE UMTANUM FLOW AT UMTANUM RIDGE COLONNADE, CROSSED NICHOLS

FIGURE 23-A PHOTOMICROGRAPHS COMPARING GLASS IN ENTABLATURE AND COLONNADE FROM FLOW E, SENTINEL GAP ENTABLATURE, REFLECTED LIGHT

FIGURE 23-B PHOTOMICROGRAPHS COMPARING GLASS IN ENTABLATURE AND COLONNADE FROM FLOW E, SENTINEL GAP COLONNADE, REFLECTED LIGHT

FIGURE A-1 SCHEMATIC REPRESENTATION OF CONCENTRATION OF VERTICAL FRACTURE-COUNTING. SEGMENTS

\section{LIST OF PLATES}

PLATE 1

PLATE 2
SENTINEL BLUFFS STRATIGRAPHIC SECTION

SCHWANA STRATIIGRAPHIC SECTION
In Pocket

In Pocket 


\section{INTRODUCTION}

PURPOSE AND SCOPE OF THE STUDY

Intraflow structures in Grande Ronde Basalt, Columbia River Basalt Group, are significant to the siting of a nuclear waste repository because of engineering design and hydrologic considerations. In addition, knowledge of intraflow structures at depth within the Pasco Basin will aid in the interpretation of the geologic history of the basin in Grande Ronde time, which, in turn, will improve our ability to predict certain geologic features that might affect repository containment.

The initial step in this study has been to examine the general character of intraflow structures occurring at the surface section of Grande Ronde Basalt exposed at Sentinel Gap. This was followed by detailed measurements of fractures in diamond dril1 core from three flows in DH-5 (a core well located $\sim 7$ kilometers from the Sentinel Gap section). Figure $1-A$ shows the location of the surface sections and $\mathrm{DH}-5$. Figure 1-B shows the stratigraphic nomenclature used in this report. The flows in $\mathrm{DH}-5$ were selected to correlate with flows covering the range of intraflow structures observed at Sentinel Gap. Fractures were then measured at the surface for the correlative flows with the objective of matching the fracture features in drill core with those occurring at the surface. In particular, it was anticipated that differences in fracture density in drill core would correspond to intraflow structures observed at the surface. In addition, textures of samples from the three flows were examined with a petrographic microscope in both reflected and transmitted light. The purpose of this part of the study was to correlate basalt textures with intraflow structures in surface outcrop, with the objective of using textures to interpret intraflow structures in drill core.

The organization of this paper reflects the approximate order in which the work was done. The initial effort in this project was directed toward the use of fracture logging of drill core, but, when fracture logging did not reveal intraflow structures in the subsurface, emphasis was shifted to the examination of basalt textures. The fracture data are included, however, both for the sake of completeness and for general information on the character of fractures in the subsurface. 


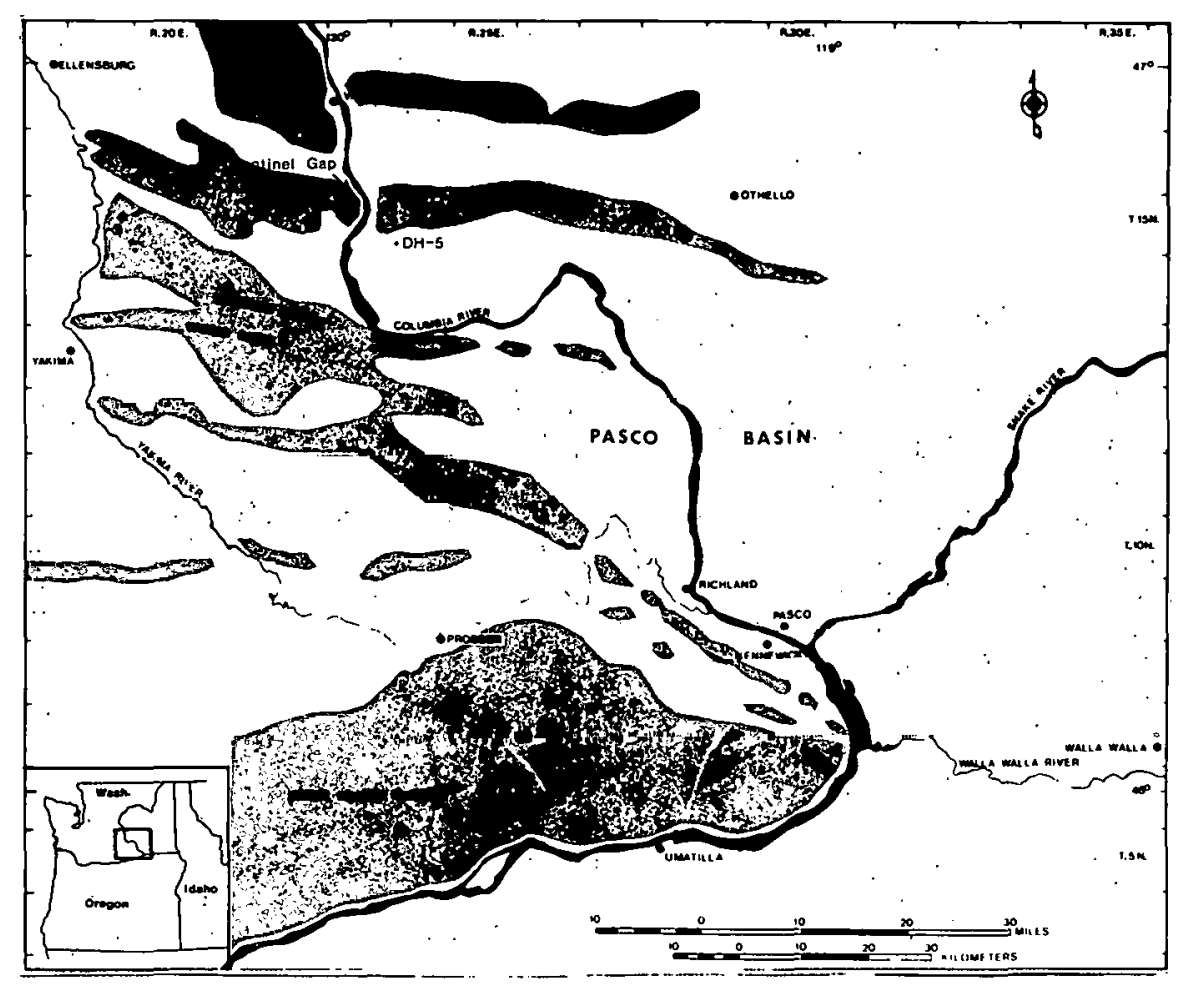

FIGURE I-A

LOCATIONS OF DH-5, PASCO BASIN AND SCHWANA $(*)$, AND SENTINEL BLUFFS $(x)$ STRATIGRAPHIC SECTIONS 


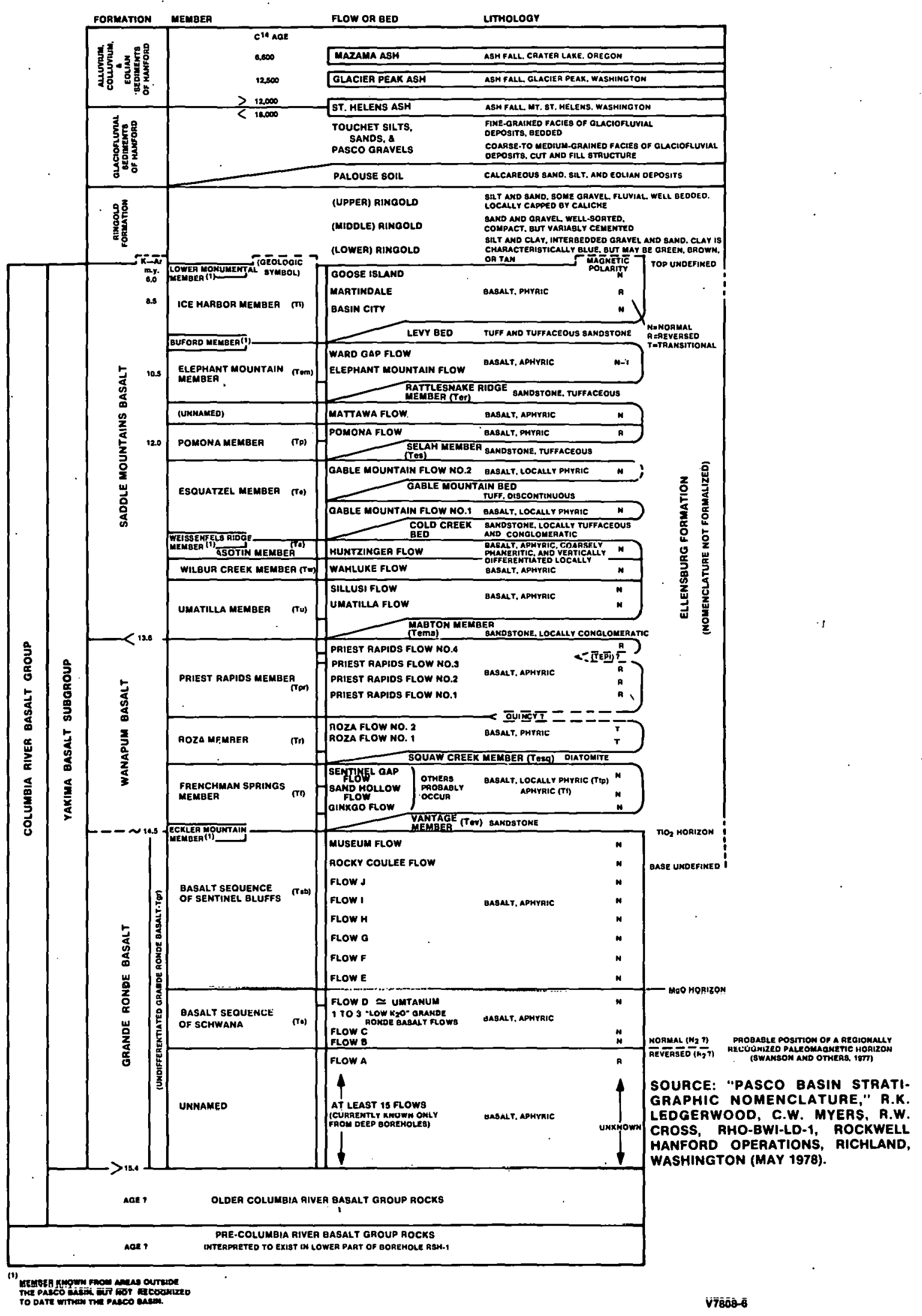

FIGURE 1-B

PASCO BASIN STRATIGRAPHIC NOMENCLATURE 


\section{PREVIOUS WORK}

Intraflow structures, particularly the formation of polygonal columns in basalt flows, have received considerable attention starting as early as the late seventeenth century (see Ryan and Sammis, 1978, for early references). No attempt will be made to review the literature written on the subject since that time. Mallet (1875), Iddings (1909), and Tomkeieff (1940) give bibliographies which trace the early development of ideas about the origin of columnar basalt. Tomkeieff (1940) examined basalt flows in northern Ireland and initiated the terminology of entablature and colonnade. This terminology has been widely applied to basalt flows where there are relatively large columns at the base of a flow (lower colonnade) in contact with smaller and commonly less regular columns in the middle or upper part of a flow (entablature). Some flows show large columns in the upper part of a flow (upper colonnade). Spry (1962) provided a modern analysis of columnar jointing based on physical principles and was able to identify the major variables which control column formation. The most significant result of his study was the recognition that column orientation need not be strictly controlled by the orientation of isotherms in a cooling basalt flow; that it, instead, is controlled by hypothetical. lines of equal stress which are closely related to isotherms, but which may deviate from them.

More recently, Ryan and Sammis (1978) have postulated that banding on some columns represents stages in the progressive opening of column fractures and thus record the advance of the fracture front as the flow cools. They have developed a model of the fracturing process which allows the interpretation of the state of stress that existed as the columns formed.

Swanson $(196 /)$ recognized a textural difference between entablature and colonnade in Grande Ronde Basalt flows in the Tieton River area of central Washington. He noted that the entablature contained a significantly higher percentage of glass than the colonnade, in some cases as much as 27 percent more. Myers (1973) described a similar 
relationship for some Yakima Basalt flows occurring near Vantage, Washington. He did report, however, that, in some flows, notably the Roza Flow, there is no obvious relationship between basalt textures and primary cooling joint patterns.

Formation of columnar joints on the surface of Mokaopuhi Lava Lake, Hawai i, has been directly observed by Peck and Minakami (1968). Their observation indicates that cracks can initiate at temperatures ranging from 900 degrees centigrade to ambient. In spite of this opportunity to follow the process of fracture formation and the fairly sophisticated reasoning of Spry (1962) and Ryan and Sammis (1978), many aspects of intraflow structures are not well understood. This paper provides some additional data on the occurrence of intraflow structures and associated basalt textures that will further constrain explanations of their origin.

. The area here studied was mapped by Grolier and Bingham (1971, 1978) and by Taylor (1976). The conventions used for designating the Grande Ronde flows at Sentinel Gap are those of Taylor (1976) (see Figure 1-B). Reidel (1978) has recently completed remapping the Saddle Mountains, including Sentinel Gap.

METHODS

\section{OBSERVATION OF GENERAL INTRAFLOW STRUCTURES}

The general character of intraflow structures occurring in exposed Grande Ronde flows at Sentinel Gap was determined by constructing a detailed stratigraphic section at a scale of 1 inch $=10$ meters using standard geologic field methods. These data were supplemented by observations of Sentine 1 Gap from the air and by the study of oblique aerial photographs.

\section{MEASUREMENT OF FRACTURES IN DRILL CORE}

Fractures were measured in drill core according to standard operating procedures. These procedures basically involve the recording of the orientation, position, length, width, filling, and physical appearance of each fracture encountered. The data were recorded in a standard format suitable for automatic data processing. 


\section{MEASUREMENT OF SURFACE FRACTURES}

Surface fractures were recorded in a manner similar to that used for the drill core. The exact procedure followed is given in the Appendix. The objective in collecting the fracture data was to simulate the fracture data collected from drill core. This was done by measuring the fractures along a series of vertical segments as illustrated in the Appendix, Figure A-1.

\section{OBSERVATIONS OF BASALT TEXTURES}

Textures of basalt samples from surface outcrops at Sentinel Gap were examined in reflected and transmitted light using standard petrographic techniques. Typically, the volume percent of glass (usually tachylite) was visually estimated, and the nature of the glass was determined-primarily by examining the texture and abundance of crystallites. In addition, the morphology of the major minerals was observed with particular attention to the morphology of opaque phases.

The samples were selected at the outcrop on the basis of intraflow structures, or in a series that approximated equal spacing of samples. For example, in flows that show a sharp break between entablature and colonnade, samples were taken adjacent to the break on either side in order to see if the intraflow structure change was reflected in textural changes in the basalt. Plates 1 and 2 show locations of the samples in relation to intraflow structures.

\section{RESULTS}

TYPES OF INTRAFLOW STRUCTURES AT SENTINEL GAP

The most common intraflow structures observed in columnar basalt are discussed by Spry (1962) and the majority of those are represented in Grande Ronde flows at Sentinel Gap. In addition, there are certain intraflow structures or features which do not involve columnar jointing, but which occur in Grande Ronde flows and are significant to the siting of a repository. All of these features are discussed, together in what follows, with an attempt to progress from a generalized discussion of gross intraflow structures to a specific description of internal flow details. 
Three basic types of internal flow structures are exposed at Sentinel Gap.

1. Relatively thin flows consisting primarily of large (one to two meters in diameter) irregular tapering columns with a relatively minor vesicular flow top and lacking a distinct entablature. These flows are invariably diktytaxitic and contain vesicle cylinders.

2. Thick flows showing multiple columnar tiers in the entablature. The colonnade consists of stubby tiered columns and is much thinner than the entablature. A clinker flow top is common and vesicles are extensively developed in the upper one-third of the flow. Fanning of entablature columns occurs locally.

3. Moderately thick flows in which there is a sharp break between entablature and colonnade defined by a difference in overall fracture abundance and column size. The colonnade in these flows commonly shows pinch-and-swell structure in the columns and the entablature is typically a complex of various radiating columnar patterns. A crude upper colonnade is usually present.

Plates 1 and 2 illustrate the three above-mentioned flow types as expressed at Sentinel Gap. Flows $G$ and $J$ and the Museum Flow are examples of Type 1; the Rocky Coulee Flow and Flows H and I together are Type 2; and, Flows B, D, E, and F are Type 3.

The columns in Type 1 flows are typically very irregular, four- to five-sided, and relatively thick (average diameter $\approx 1.5$ meters). The cooling joints typically traverse the entire thickness of the flow. Vesicle cylinders extend from $\sim 0.2$ meter above the base to near the middle of the flow. Vesicles typically occupy the upper third of the flow, with diameter increasing upward to a thin flow top. Typical vesicle cylinders are shown in Figure 2.

The Rocky Coulee Flow is shown in Figure 3 as an example of Type 2 flows. Note the "brickbat" jointing in the upper entablature and the extensive development of entablature at the expense of the colonnade. The tiers of columns are separated by knobby, platy zones detailed in Figure 4. The disintegration of tiered entablature columns to brickbat jointing is approximately coincident with the first occurrence of vesicles. The vesicles are typically layered in size and abundance. The flow top is relatively thick and is locally pillowed. Thick flow lobes or units occupy the top of the flow and culminate in a red, clinker flow 


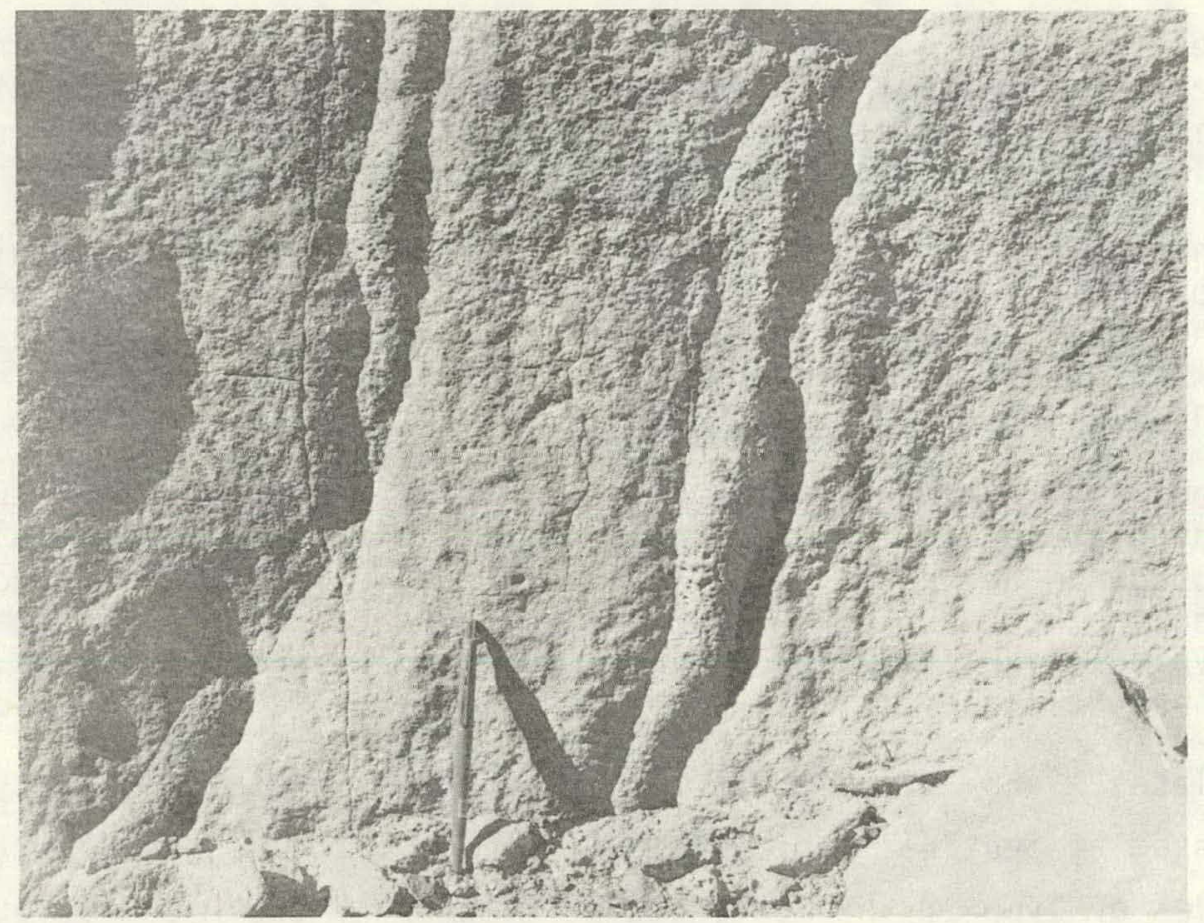

FIGURE 2

VESICLE CYLINDERS IN FLOW J, SENTINEL GAP

(The pen is approximately 13 centimeters in length.) 


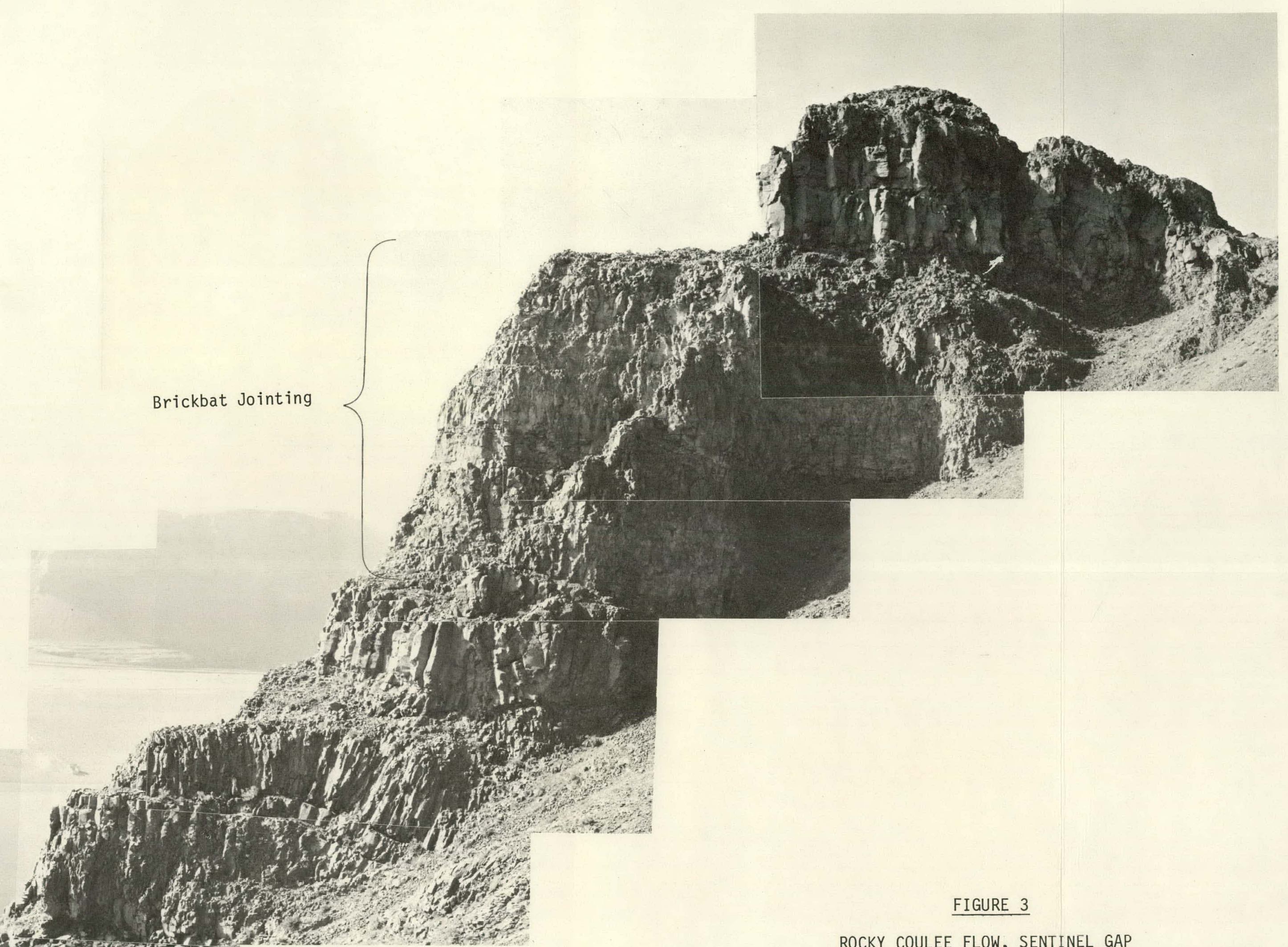

a 1 - 1 -

ROCKY COULEE FLOW, SENTINEL GAP

Note tiered aspect of the flow and extensive brickbat jointing in upper part. The top part of the photograph shows a distinct
flow lobe figured in Plate 1 . The flow is about 60 meters in thickness.) 


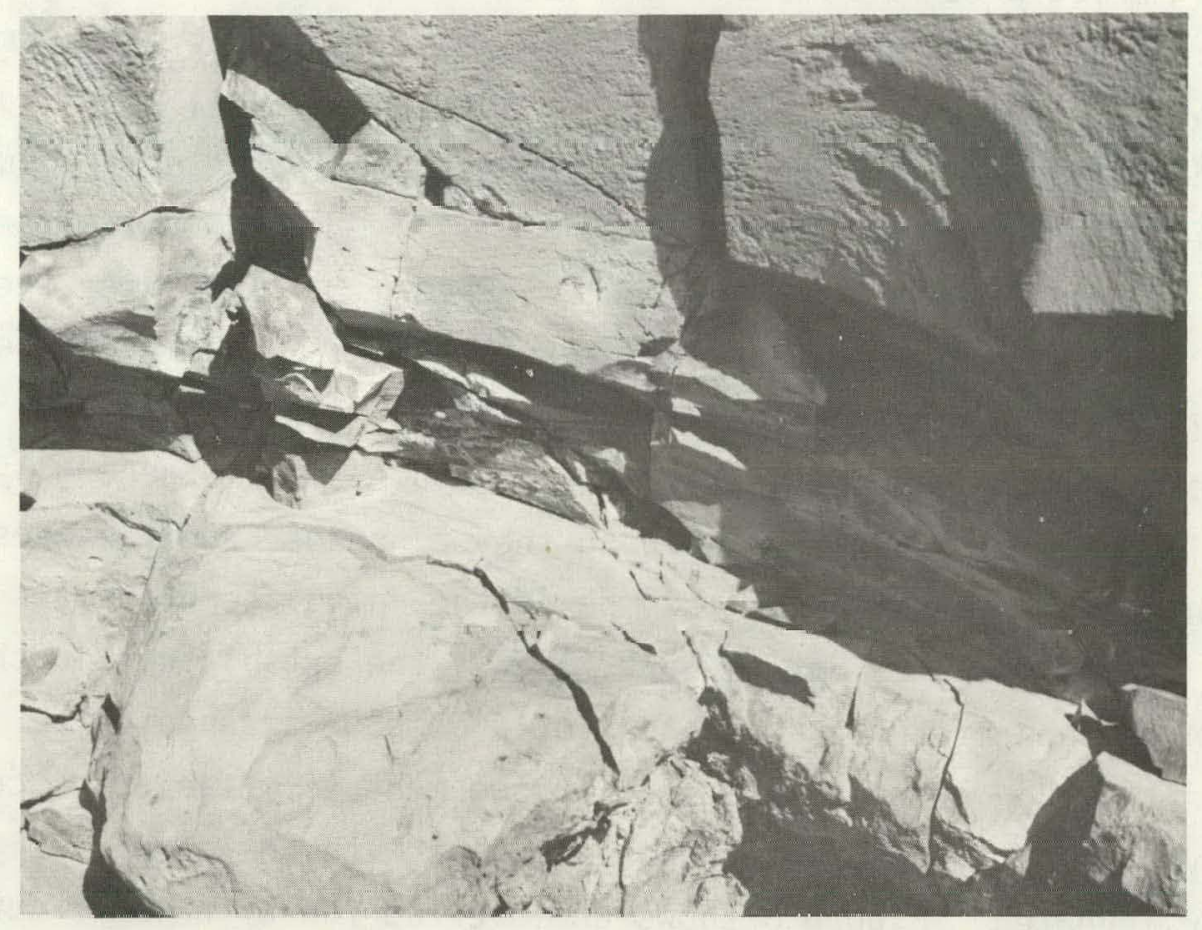

FIGURE 4

PLATY FRACTURE ZONE IN THE ROCKY COULEE FLOW

(The concentration of irregular low-angle fractures. Width of zone is about 17 centimeters.) 
top. Flows $\mathrm{H}$ and I are similar to the Rocky Coulee, in that the entablature columns are tiered, but brickbat jointing is not developed in the upper part of the flow and vesicle layering is strongly developed. Indeed, a marked break in vesicle abundance was picked as the flow contact between $\mathrm{H}$ and I by Taylor (1976). Cooling joints pass through this "contact," indicating that Flows $H$ and $I$ are a single cooling unit at Sentinel Gap. A thick red clinker flow top marks the upper boundary of the flow.

Type 3 flows are typified by Flow E. Figure 5 illustrates the characteristic distinct boundary between entablature and colonnade. Columns in the colonnade are relatively small to moderate size and show we 11-developed pinch-and-swell features. Column size is generally smaller in the entablature relative to the colonnade and fractures much more abundant. Orientation of columns in the entablature appears chaotic, but, as pointed out by Spry (1962), the entablature in these flows can be thought of as consisting of a complex arrangement of rather simple units. For example, a common arrangement of entablature columns is to have adjacent groups of fanning columns with one group upright and the other inverted. Figure 6 shows an inverted fan of columns surrounded by hackly entablature. An upper colonnade is commonly noticeable in the upper one-half of the flow (Figure 5 ).

\section{DETAILS OF FRACTURE MORPHOLOGY}

Certain features occur sporadically in all fluw types or are at least locally common to all flows. Most of these features are noted by Spry (1962).

Pinch-and-swel1 of columns is shown in Figures 7-A and 7-B. These features range from extremely regular and periodic to virtually nonexistent. Almost all columns in the colonnade have at least some gently curving surfaces and an irregular pinch-and-swel1 is noticeable in most flows.

Ball-and-socket joints typically occur in the colonnade of flows with regular columns (Figure 8). Regularly spaced ball-and-socket and/or niche joints create a feature known as "stack of Dutch cheeses," Spry (1962) visible in the upper part and in Figure 7-B. 


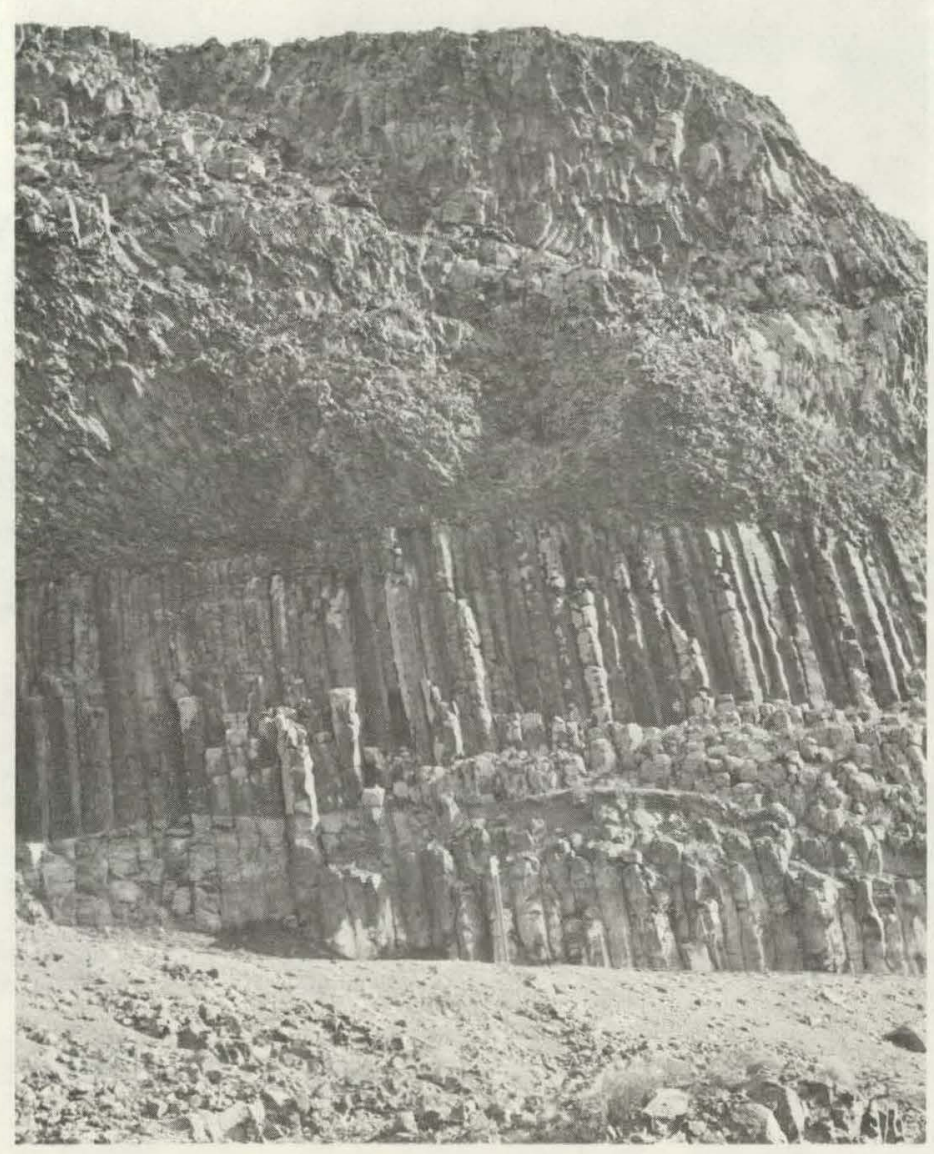

FIGURE 5

SHARP CONTACT BETWEEN ENTABLATURE AND COLONNADE, FLOW E, SENTINEL GAP

(The cliff height is approximately 55 meters.) 


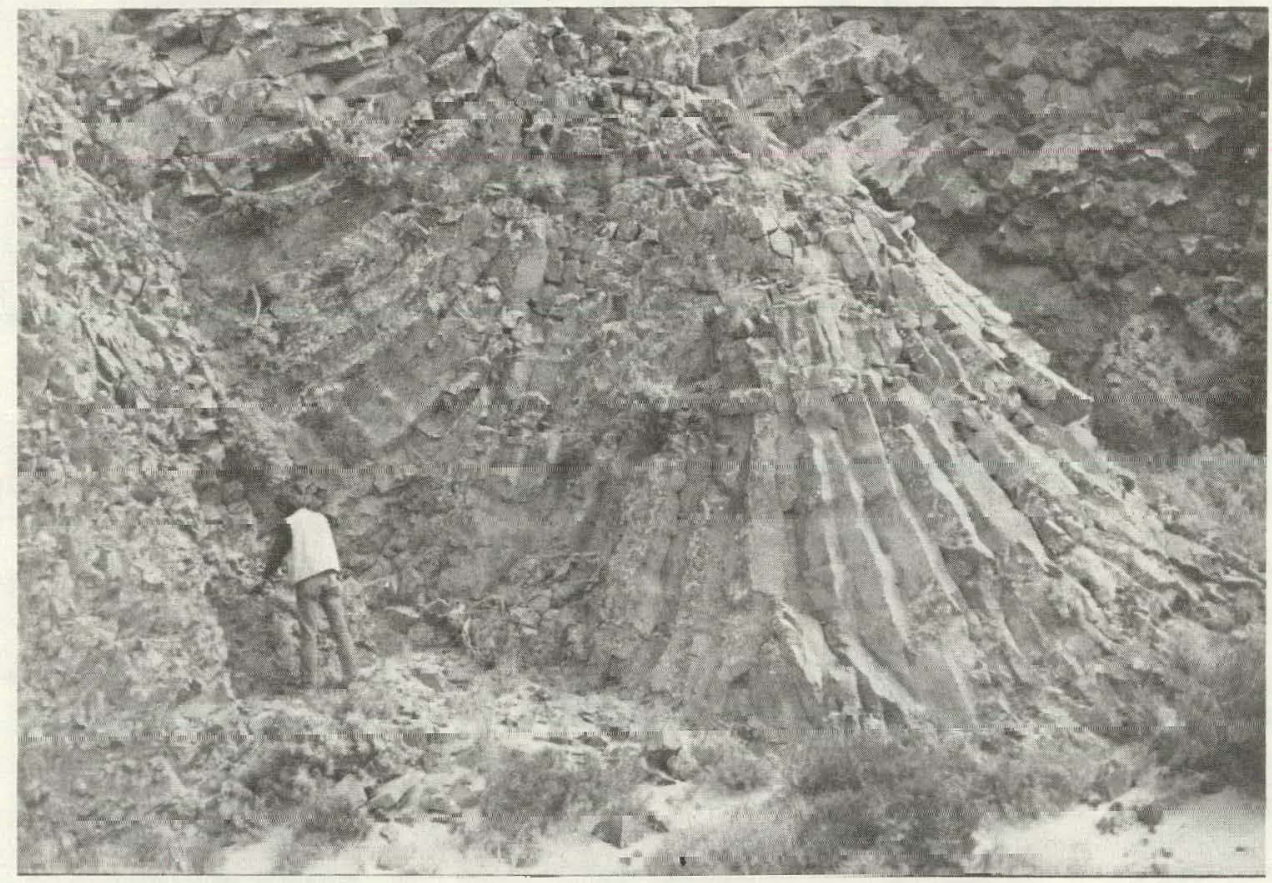

FIGURE 6

INVERTED FAN ARRANGEMENT OF ENTABLATURE COLUMNS IN FLOW E 


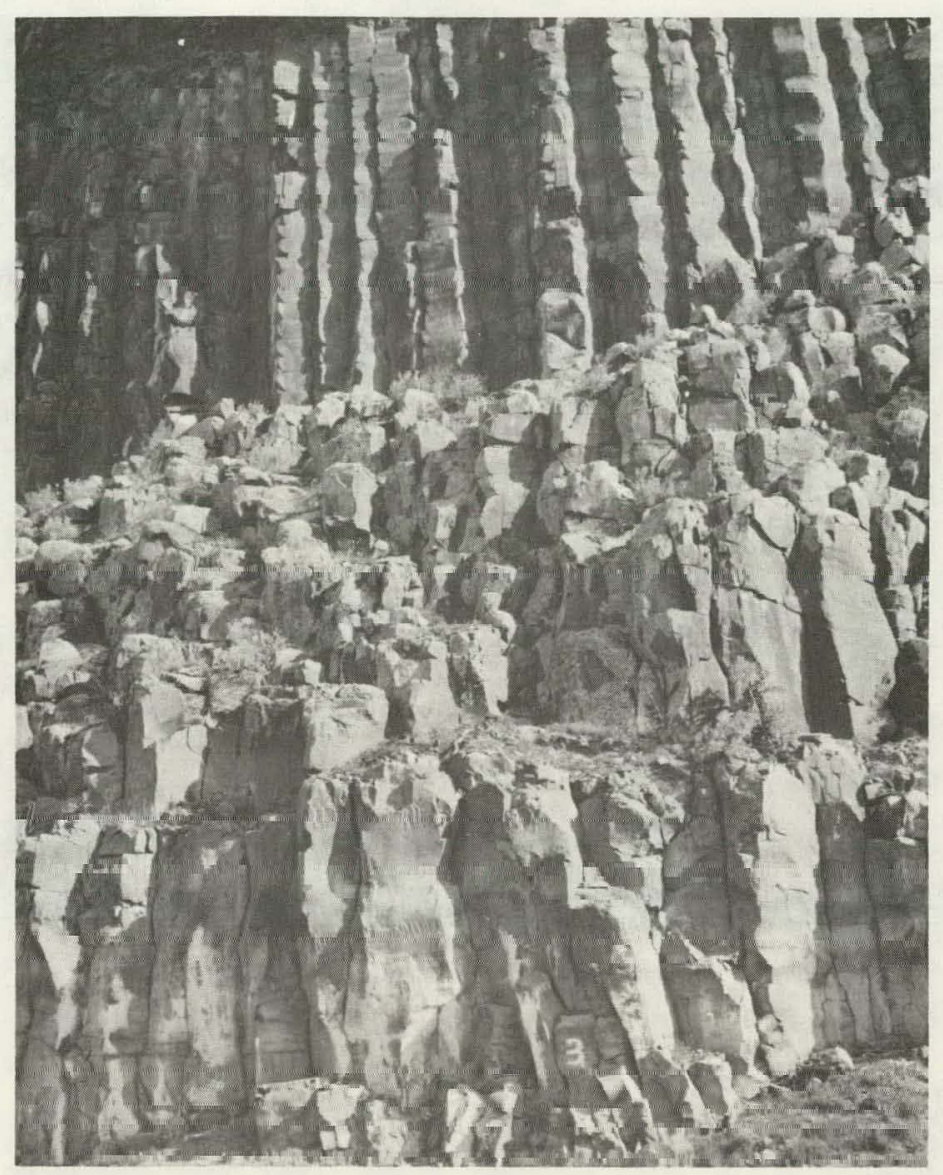

FIGURE 7-A

PINCH-AND-SWELL IN COLONNADE COLUMNS, FLOW E

(Pinch-and-swell occurs with varying degrees of regularity and on different scales.) 


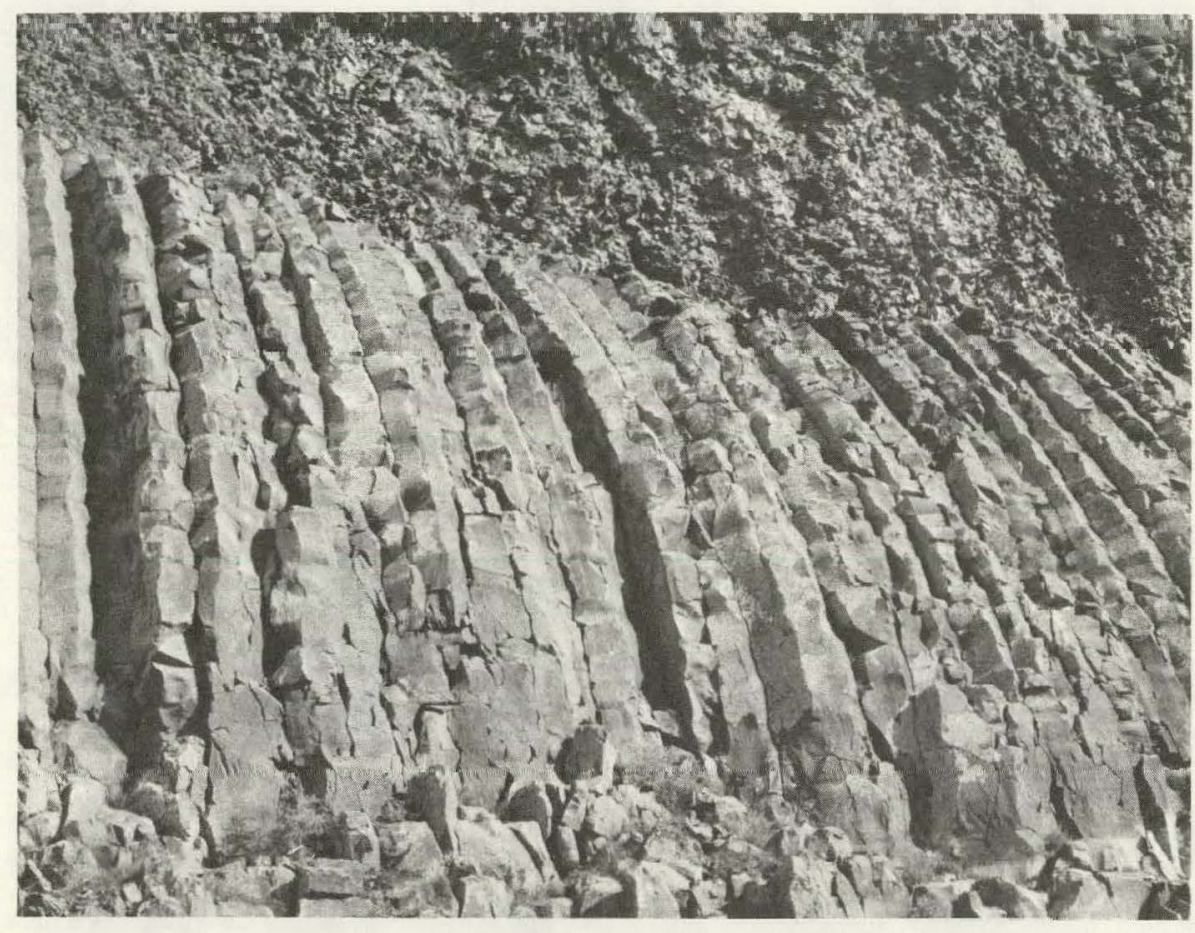

IIGURE 7-B

DETAIL OF REGULAR PINCH-AND-SWELL FEATURES IN FLOW E

(The sharp entablature--colonnade contact is also shuwn. Niche juinls yive "slack of Dulch cheeses" effect in some columns. Compare with Figure 5 for scale.) 


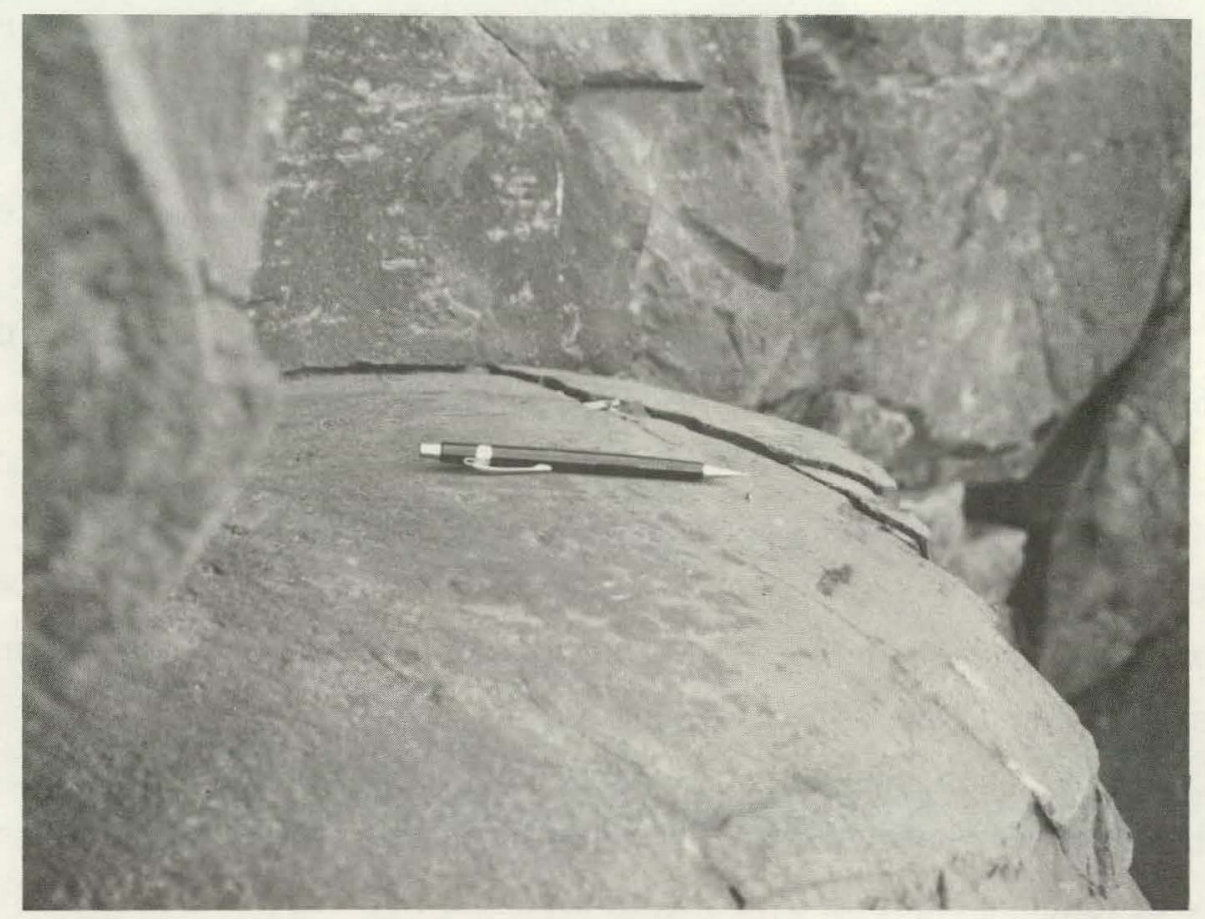

FIGURE 8

A BALL-AND-SOCKET JOINT IN FLOW E

(Note that the pen is about 13

centimeters in length.) 
Chisel marks are steps or grooves on fracture surfaces which occur on a scale of 0.5 meter to 1 centimeter. Figures 9-A and 9-B show a typical occurrence of chisel marks on two different scales in the Rocky Coulee Flow. Figure 10 illustrates a slightly different chisel mark morphology found on secondary fractures in the entablature Flow E. Associated with chisel marks is a change in surface roughness along a fracture as illustrated in Figure 11. In the entablature, it is common for early, primary fractures to have a substantially rougher surface than the later secondary surfaces. However, in Figure 11, both features occur on essentially the same surface suggesting that the fracture propagated in two stages as "fingers." A possible explanation is that surface roughness is controlled by the temperature at which the fracture forms in conjunction with the texture of the rock at the time of cracking. Surface roughness may well affect radionuclide adsorption and, hence, a greater understanding of its distribution and origin is desirable.

Recently, Ryan and Sammis (1978) have suggested that differences in surface roughness occurring in bands on colonnade column faces represent elastic (smooth) and inelastic (rough) modes of fracturing. Generally, differences in surface roughness on colonnade column faces are not as great as that shown in Figure 11, but, following their suggestion, it does seem reasonable that two modes of fracturing are involved. It is worth noting, however, that surface roughness differs in a general way from flow to flow and within flows. It is generally true that colonnade columns are smoother than rough entablature columns, but areas of smooth fracturing in the entablature also occur; i.e., both the roughest and the smoothest fracture surfaces commonly occur in the entablature.

In addition, Ryan and Sammis (1978) have interpreted chisel marks associated with banding on colonnade columns as indicating the presence of antiplane shear in addition to pure tension during the fracturing process. Both banding and chisel marks (lance fractures in the Ryan and Sammis terminology) are visible in Figure 10. Noticing that the most obvious chisel marks are associated spatially with a pinch feature, it is interesting to speculate that pinch-and-swell features are the result of antiplane shear that could not be accommodated by lance fractures. 


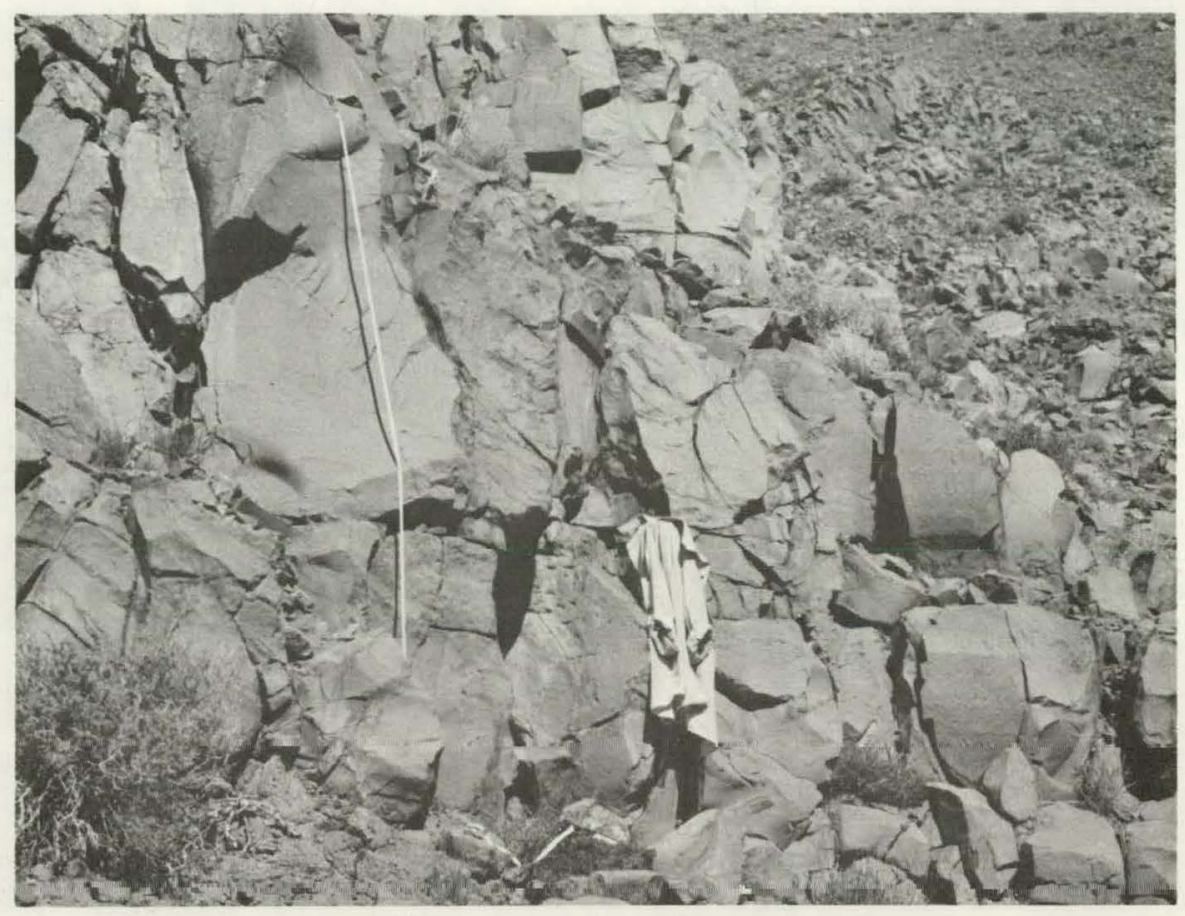

FIGURE 9-A

CHISEL MARKS IN THE LOWER PART OF THE ROCKY COULEE FLOW

(The smal1-scale chisel marks or lance fractures [Ryan and Sammis, 1978] are shown in the lower left of Figure 9-B.) 


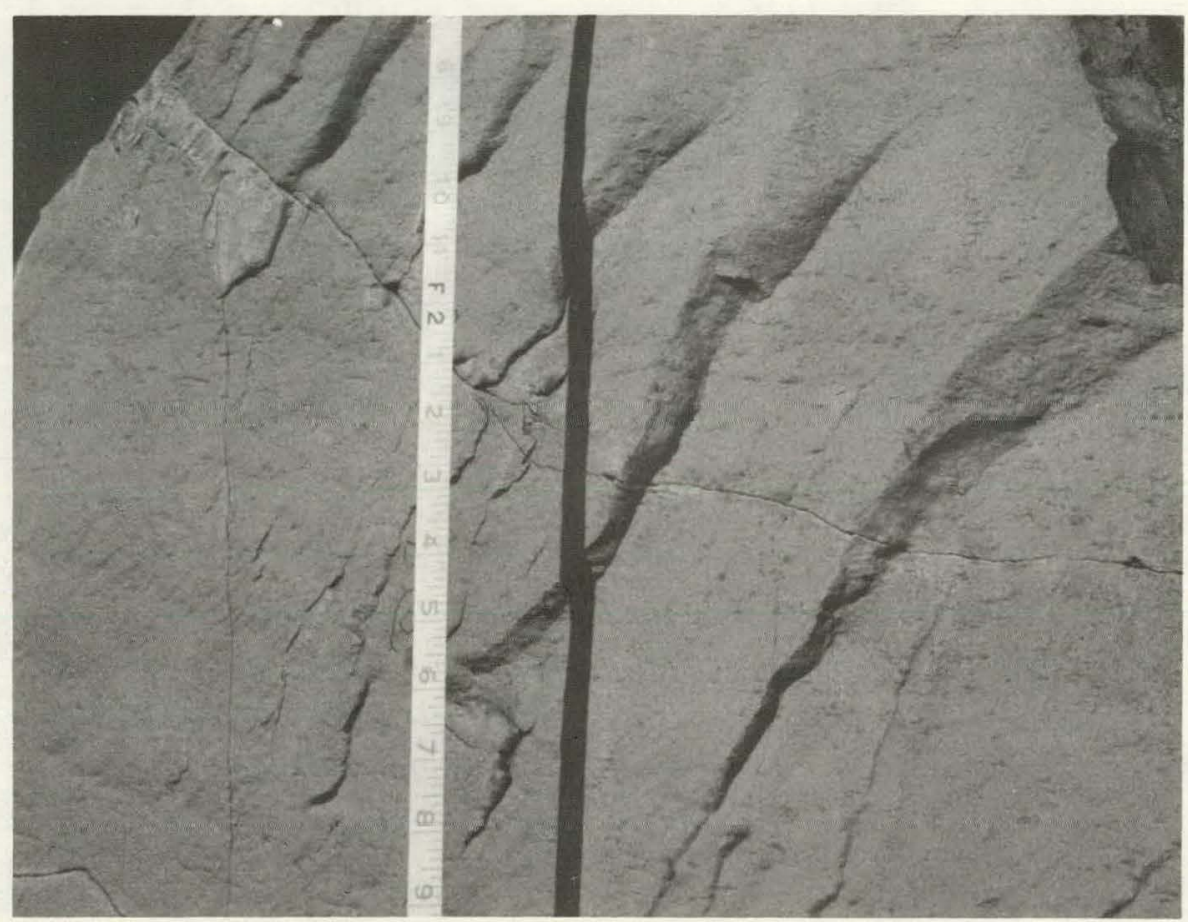

FIGURE 9-B

CIIISEL MARKS IN TII LOWER PART OF TIIL ROCKY COULEE FLOW

(The small-scale chisel marks or lance fractures [Ryan and Sammis, 1978] are shown in the lower left.) 


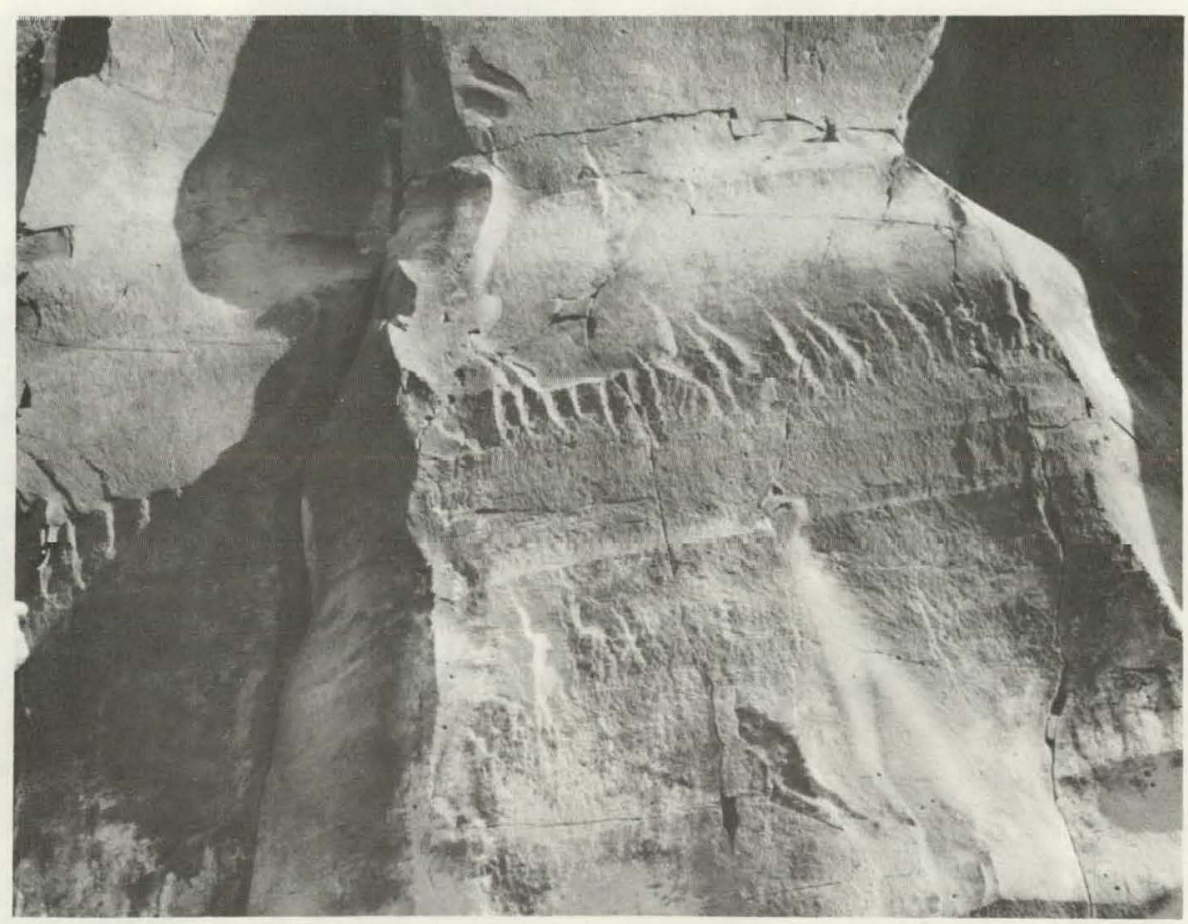

FIGURE 10

CHISEL MARKS ON A JOINT SURFACE OF FLOW E IN THE ROCKY COULEE FLOW

(According to Ryan and Sammis, 1978, these bands mark progressive stages of fracturing in the upward direction. See Figure 7-A for scale.) 


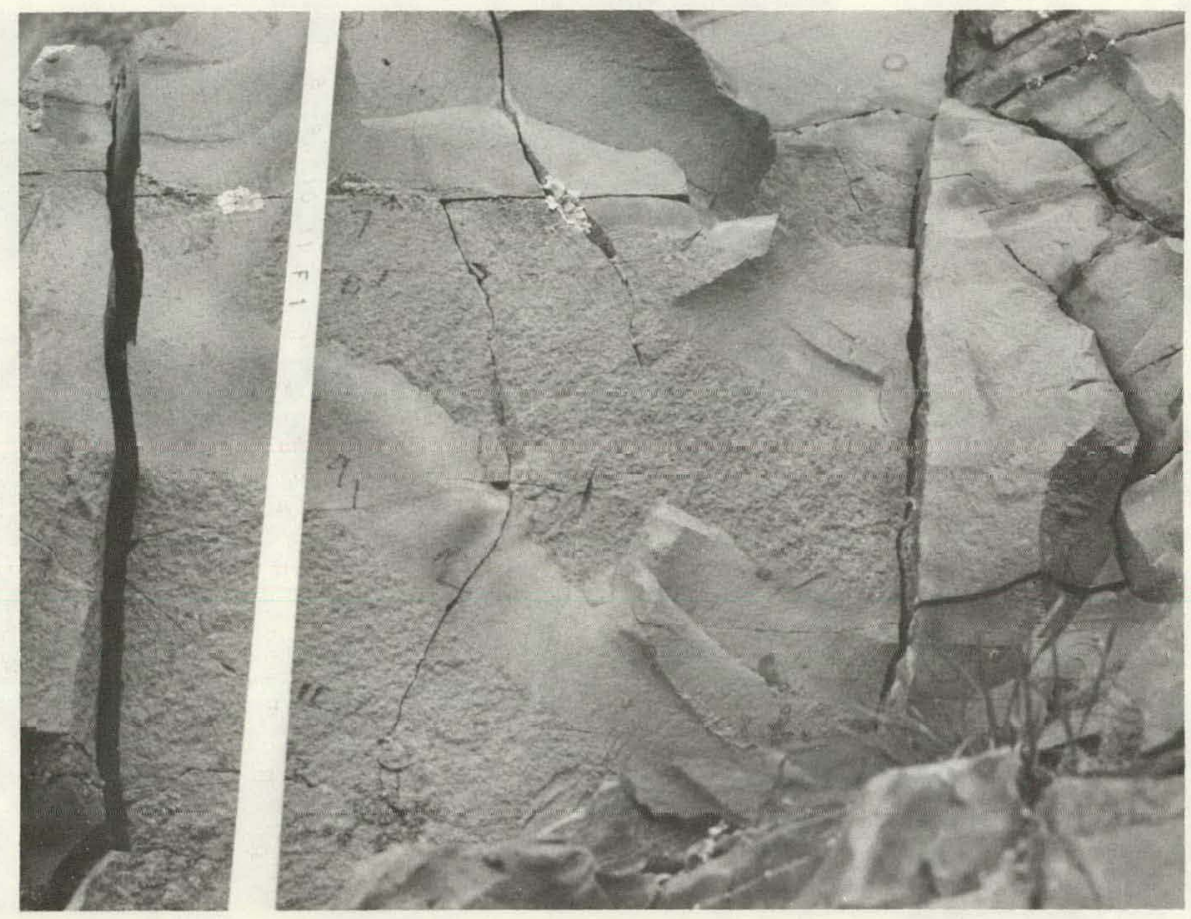

FIGURE 11

DIFFERENCES IN SURFACE ROUGHNESS ON A FRACTURE SURFACE IN THE ENTABLATURE OF FLOW E

(These features may represent different stages of fracture propagation, possibly at different temperatures, or they may represent elastic [smooth] and inelastic [rough] stages of cyclical fracturing [Ryan and Sammis, 1978].) 


\section{PLATY FRACTURE ZONES}

Platy fracture zones occur in almost all flows, but the degree and character of their development vary greatly from flow to flow. Figure 12, for example, illustrates the knobby fracture of a platy zone in the Rocky Coulee Flow. Curvilinear, subhorizontal fractures, or platy zones in Flow E lack the knobby features and consist of closely spaced parallel fractures (Figure 13). The origin of either type of platy fractures is not well understood, but they are at least in some way related to primary cooling and perhaps have been enhanced by tectonic movement. Holmgren (1968) studied platy fractures in Columbia River Basalt and concluded that they formed after the major vertical cooling joints. He ascribed them to alignment of elongate minerals in the basalt. Locally, at Sentinel Gap, near-horizontal platy fracture zones occur which are clearly tectonic in origin. These features transect column tiers and locally show brecciation and minor internal folds. These horizontal tectonic zones are complemented by near-vertical closely spaced fracture zones which affect weathering and erosion patterns along Sentine 1 Bluffs. Typical such features are shown in Figures 14-A, 14-B, and 14-C. The vertical zones almost certainly have hydrologic significance, since they are likely to transect an entire flow or group of flows potentially connecting interflow zones.

\section{BASAL PILLOW PALAGONITE}

Basal pillow palagonite zones are an intraflow structure that forms when a basalt flow enters a lakc or other body of water. Excellent examples of this type of feature occur within and to the north of Sand Hollow in the Frenchman Springs flows (Mackin, 1961), but occurrence in the Grande Ronde Basalt at Sentinel Gap is limited. An example of a local basal pillow zone is shown in Figure 15. Thick pillowed zones are reported, however, in Grande Ronde flows near Vantage (Hole-in-the-Wall Section, Bentley, 1977), and farther north near the mouth of Moses Coulee. The hydrologic significance of these features must not be underestimated and further study is needed on frande Ronde flows north of 


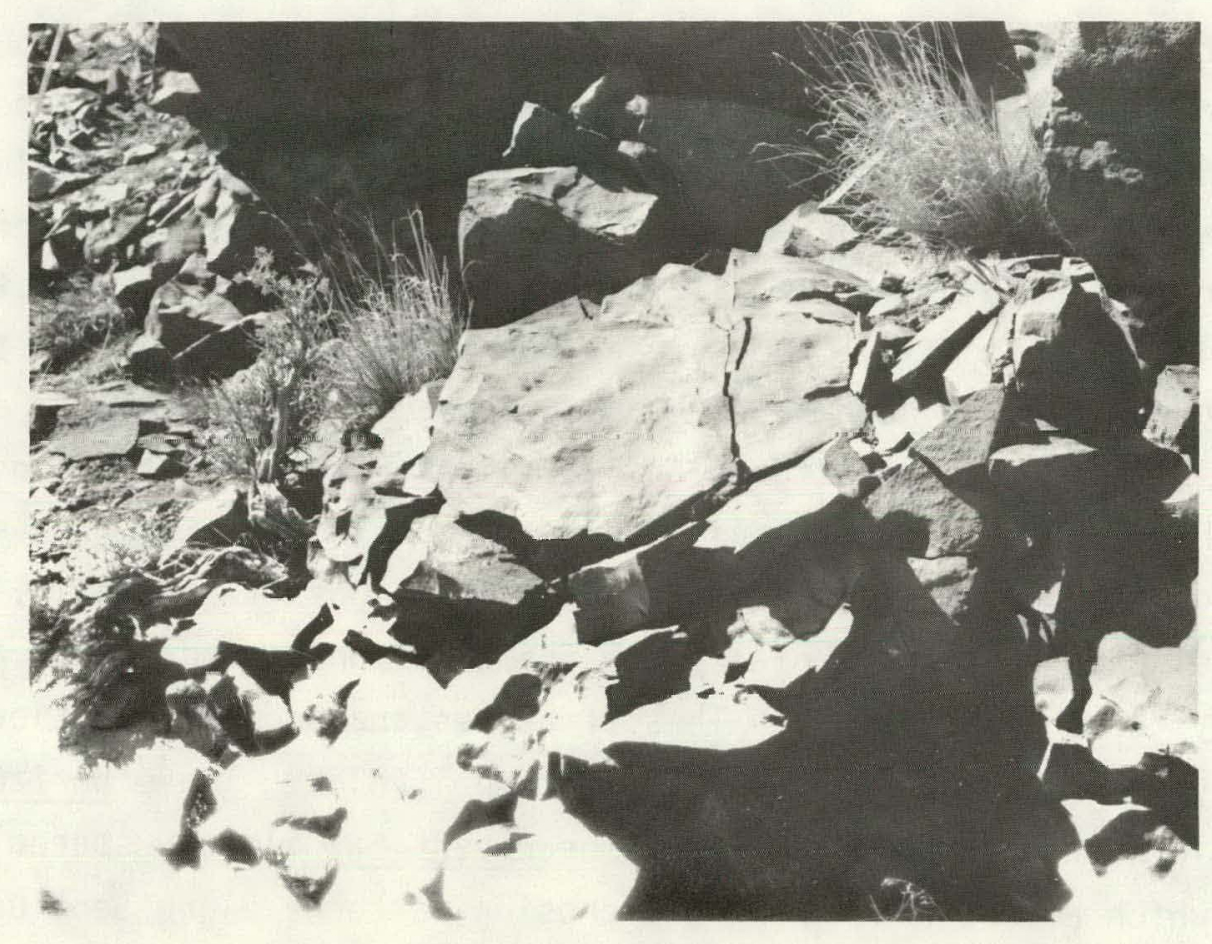

FIGURE 12

KNOBBY FRACTURF SIIRFACE ON PLATY ZONE FRACTURE

IN THE ROCKY COULEE FLUW 


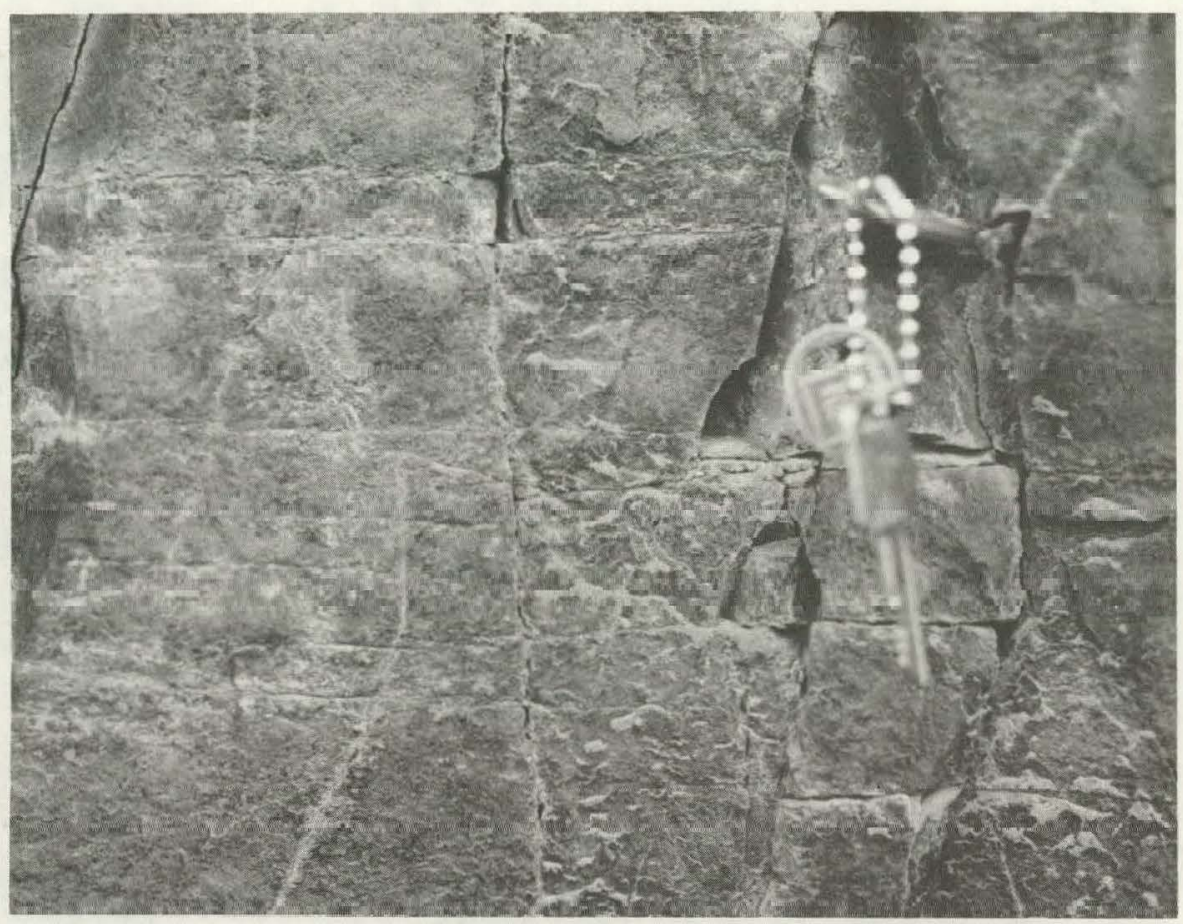

FIGURE 13

CLOSELY SPACED, SUBPARALLEL FRACTURES IN A PLATY ZONE, FLOW E

(These fractures lack undulation characteristics of platy fracture zones in the Rocky Coulee Flow.) 


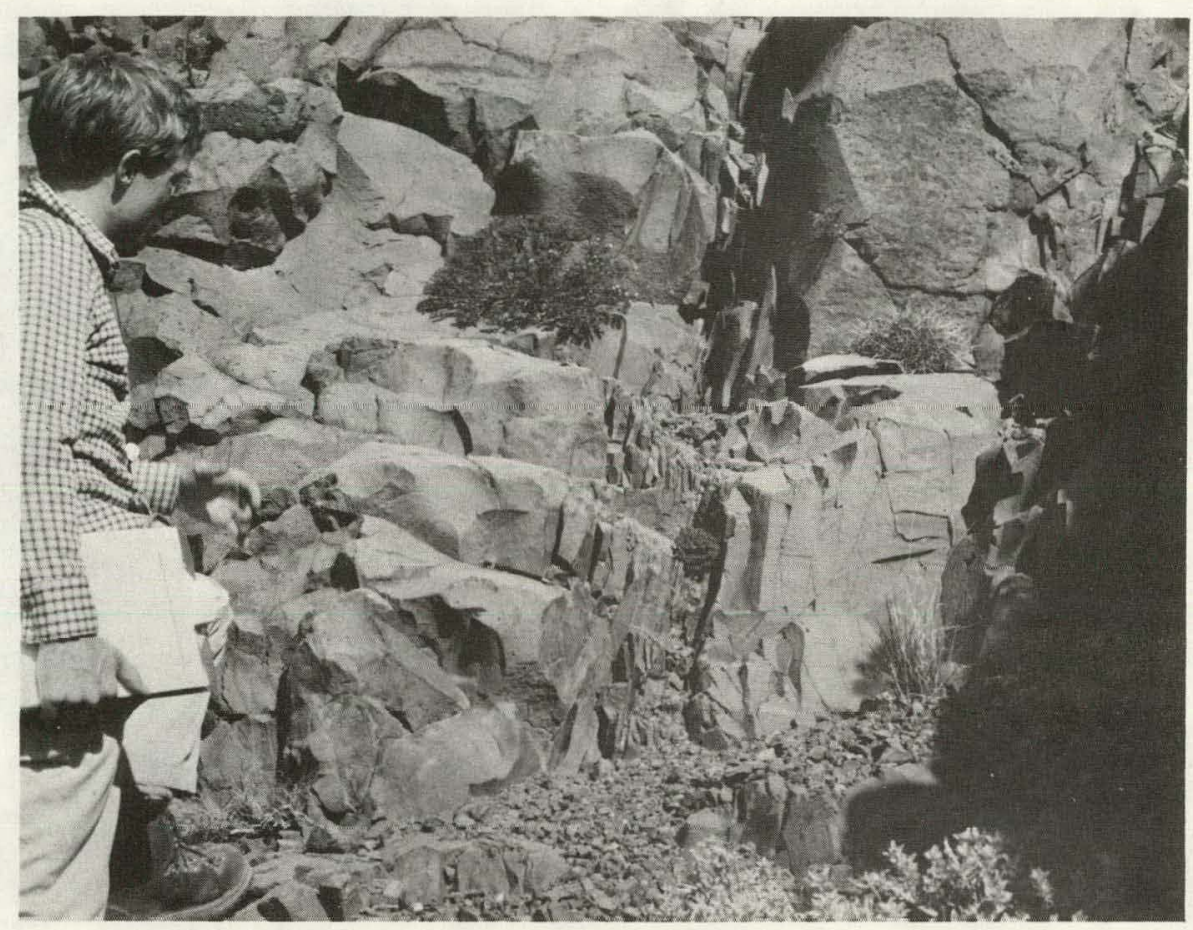

FIGURE 14-A

TECTONIC FRACTURES AT SENTINEL GAP

(Closely spaced tectonic fractures, near-vertical, in the Rocky Coulee Flow.) 


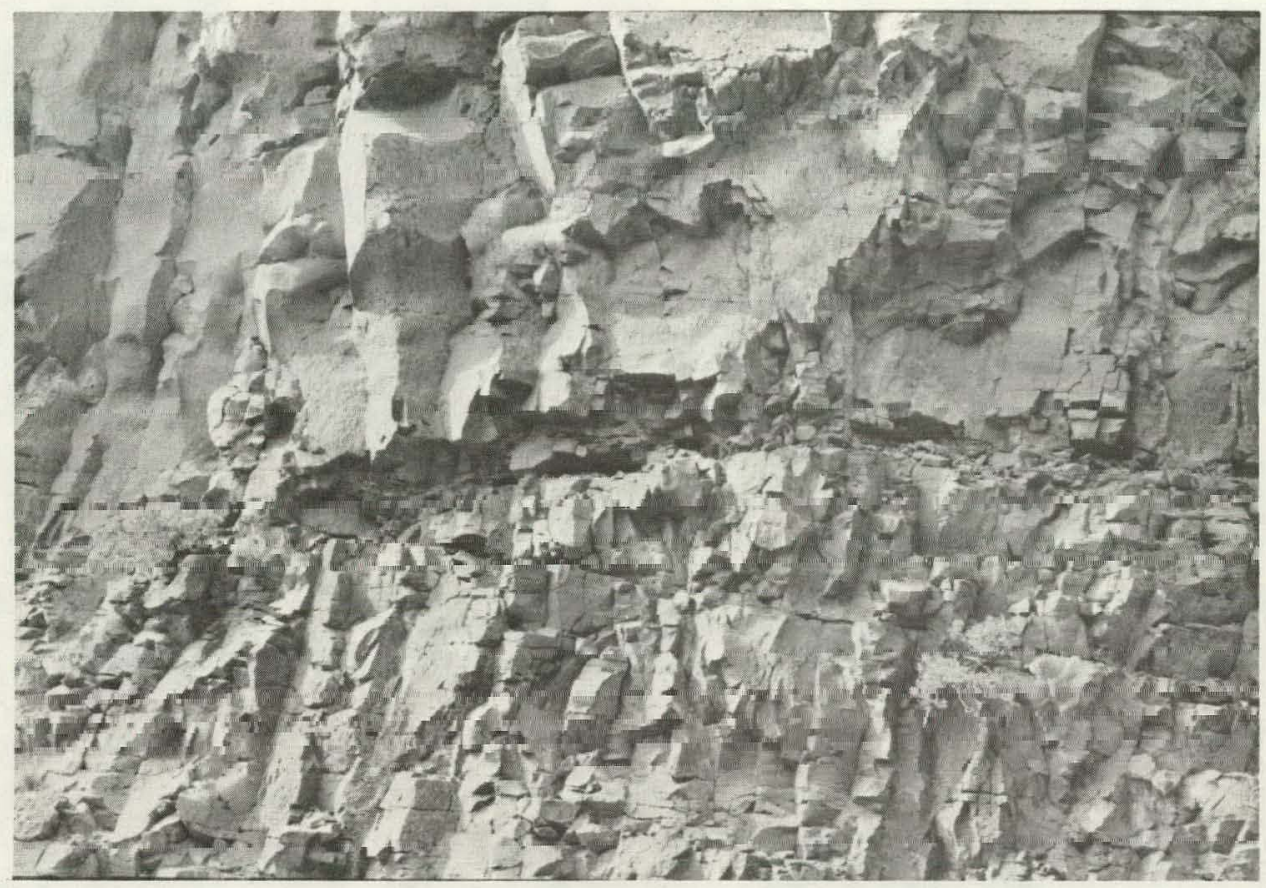

FIGURE 14-B

TECTONIC FRACTURES AT SENTINEL GAP

(Subhorizontal tectonic fractures. Note that these cut across columns at angles other than 90 degrees.) 


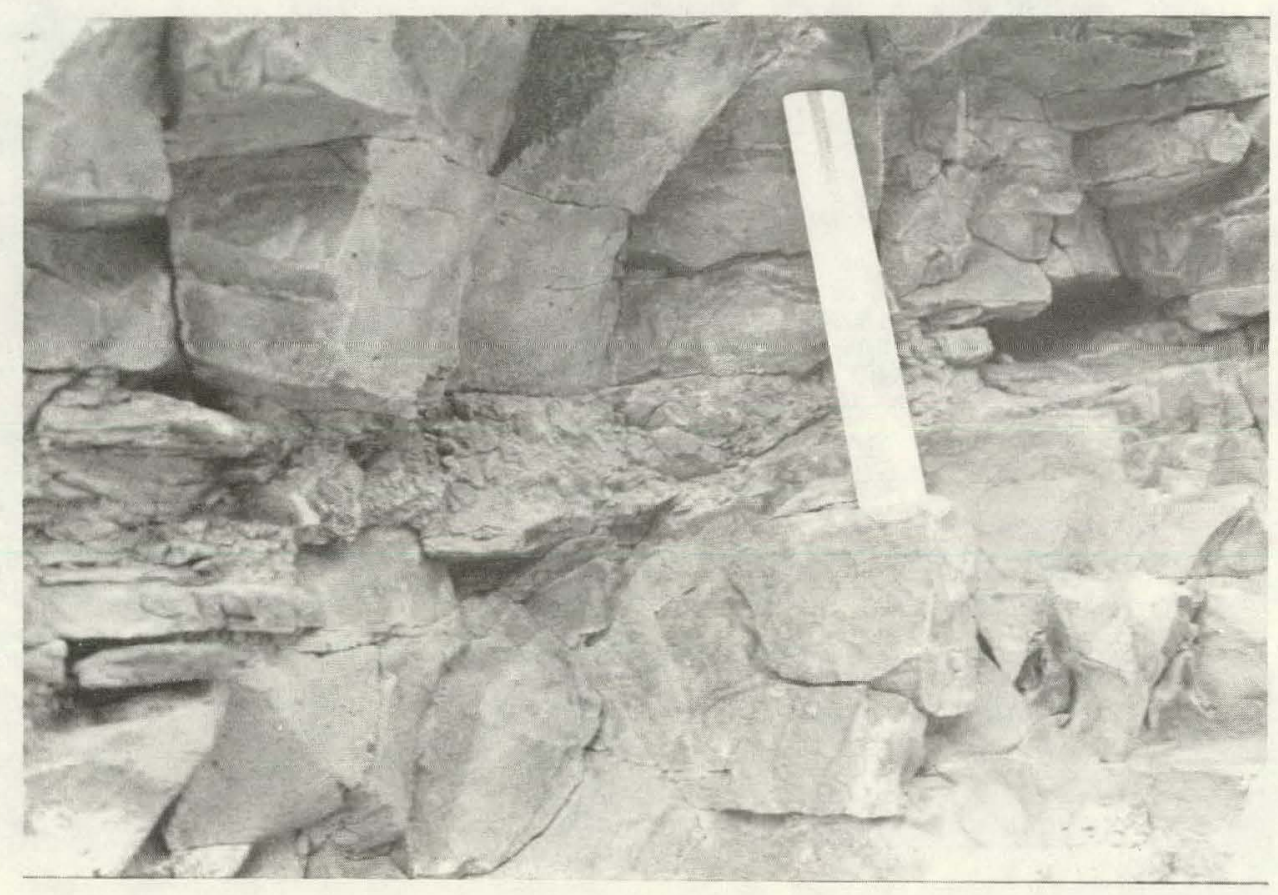

FIGURE 14-C

TECTONIC FRACTURES $\Lambda$ T SENTINEL GAP

(Narrow breccia zone occupying one of the fractures shown in Figure 14-B. The ruler is approximately 16 centimeters in length.) 


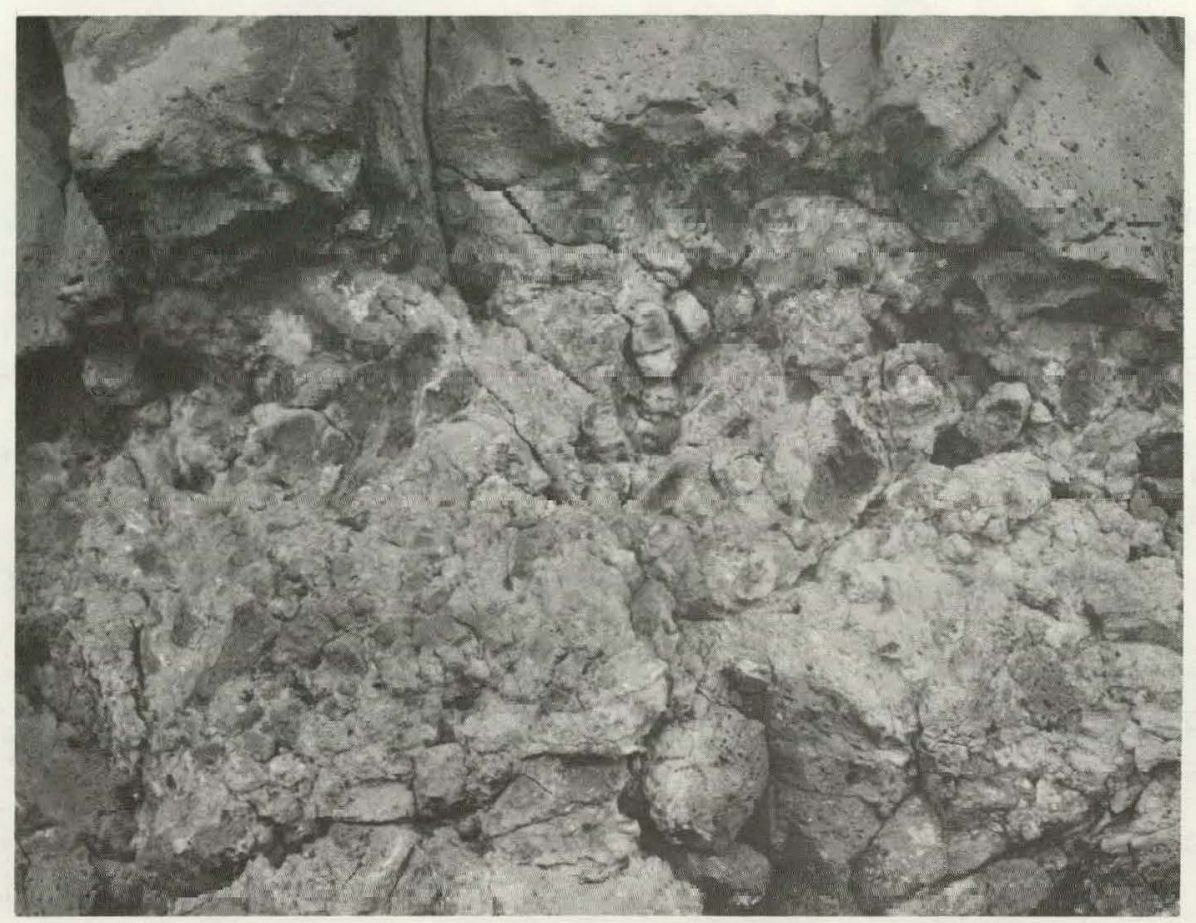

FIGURE 15

THIN PILLOWED ZONE AT THE BASE OF FLOW $\mathrm{J}$

(Palagonite occupies the interstices of the small pillows. Width of center culuini al lop of photo is about 0.75 meter.) 
Vantage in order to determine their extent toward and into the Pasco Basin and to interpret their mode of origin. To date, no significant pillowed zones have been observed in drill core of Grande Ronde Basalt in the Pasco Basin, but a prediction as to the probability of such occurrence needs to be made.

\section{RESULTS FROM DRILL CORE MEASUREMENTS}

A fracture, as logged in drill core, was effectively defined as any subplanar or planar aperture, either filled or unfilled, which transects or partially transects the core. Some of the fractures were drilling or hammer breaks and these have been excluded from the dala presented below. The vast majority of fractures contained some kind of 1111 iny material and, furthermore, the majority of fractures is relatively narrow, that is less Lhan 1 millimeter in width. Even the fairly rare wide fractures are generally filled, although it must be recognized that fracture fillings themselves commonly have some visible porosity and presumably some permeability. The mineralogy of the fracture fillings was not determined, but, following Ames (1978), they are assumed to be primarily montmorillonite clays. Unfilled fractures generally have narrow apertures ( $<0.5 \mathrm{millimeter),} \mathrm{but} \mathrm{there} \mathrm{are} \mathrm{rare} \mathrm{fractures} \mathrm{or}$ fissure openings 4 to 10 millimeler's in width that arc unfilled or only partially filled.

Of the 1,454 fractures logged in 3 Grande Ronde flows from $\mathrm{DH}-5,83$ percent were filled and 17 percent unfilled. The percentage of filled fractures for each flow logged is as follows: Museum Flow 87 percent; Rocky Coulee Flow 77 percent; and, Flow E 86 percent.

Results from drill core fracture measurements are shown graphically in Figures 16 to 19 as plots of distance (vertical axis) versus abundance of fractures, percentages of high-angle fractures, and maximum fracture length, respectively. The purpose of these plots is to show changes in fracture characteristics with position in a flow. DH-5 is an essentially vertical core hole at a location where the flows are interpreted to have a dip of 9 degrees south and a strike of north 80 degrees west. These changes, then, should reflect intraflow structures observed and measured 


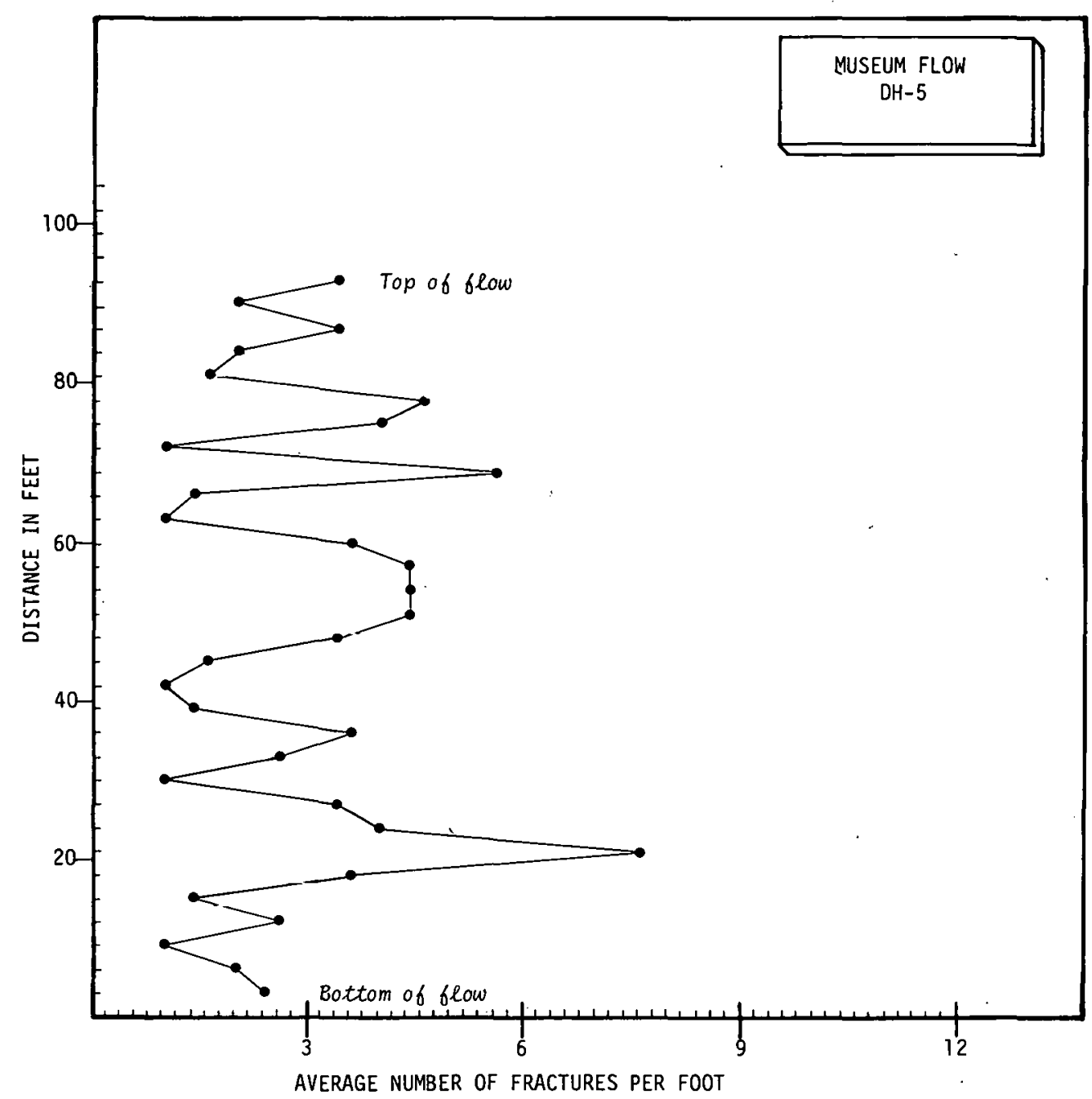

FIGURE $16-A$

POSITION IN FLOW PLOTTED AGAINST AVERAGE NUMBER

OF FRACTURES PER FOOT FOR THE MUSEUM FLOW FROM DH-5 


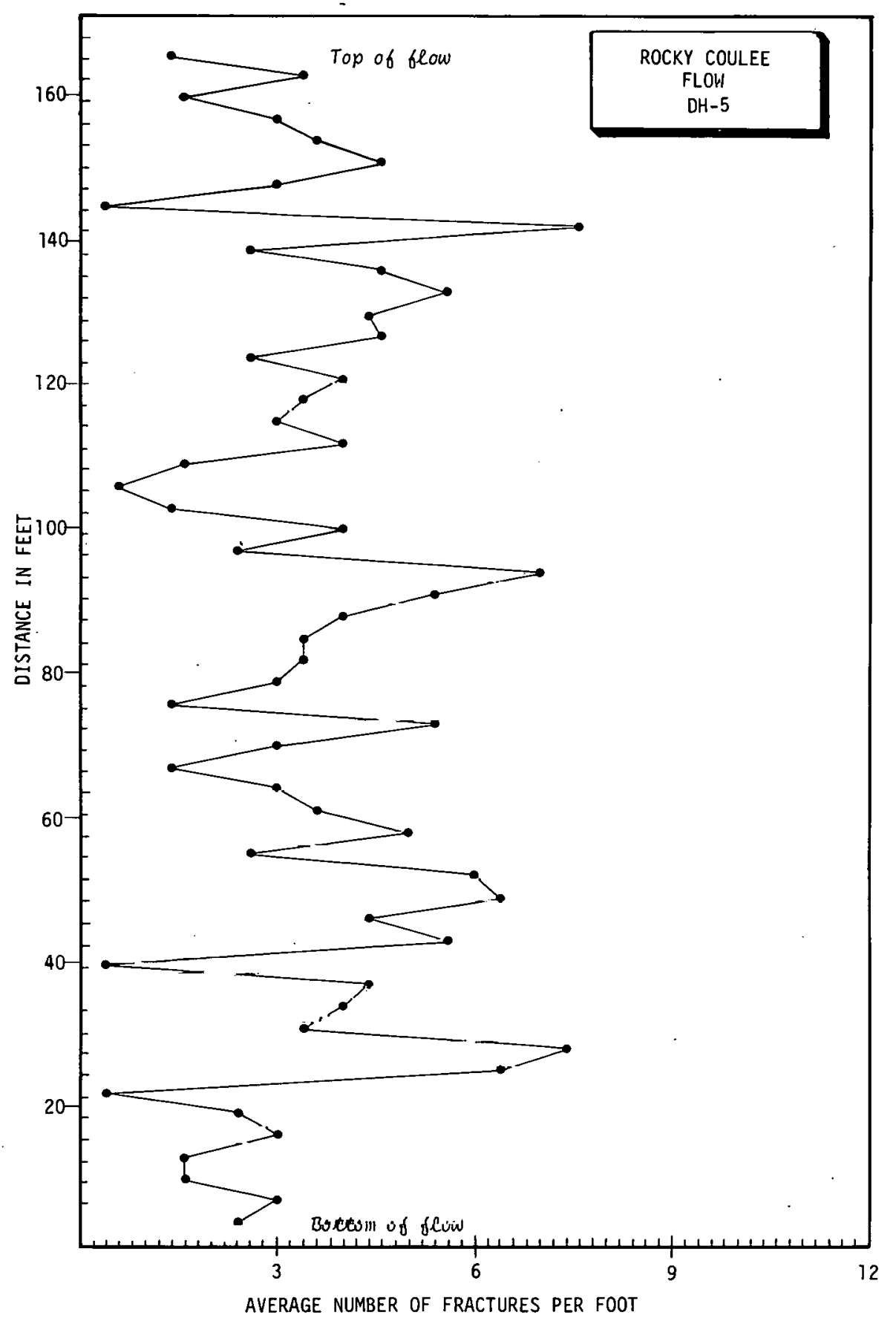

FIGURE 16-B

POSITION IN FLOW PLOTTED AGAINST AVERAGE NUMBER

OF FRACTURES PER FOOT FOR THE ROCKY COULEE FLOW FROM DH-5 


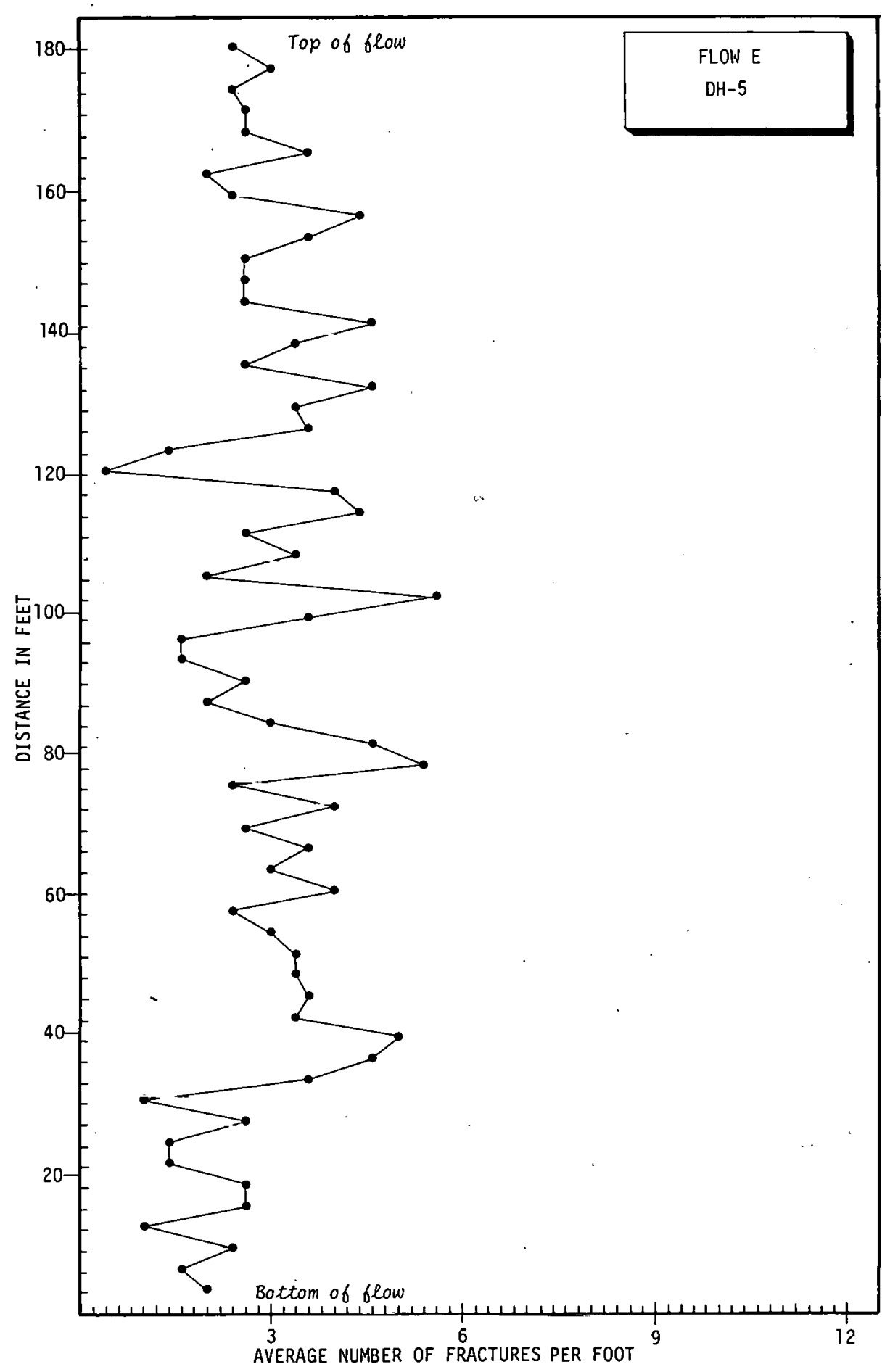

FIGURE 16-C

POSITION IN FLOW PLOTTED AGAINST AVERAGE NUMBER OF FRACTURES PER FOOT FOR FLOW E FROM DH-5 


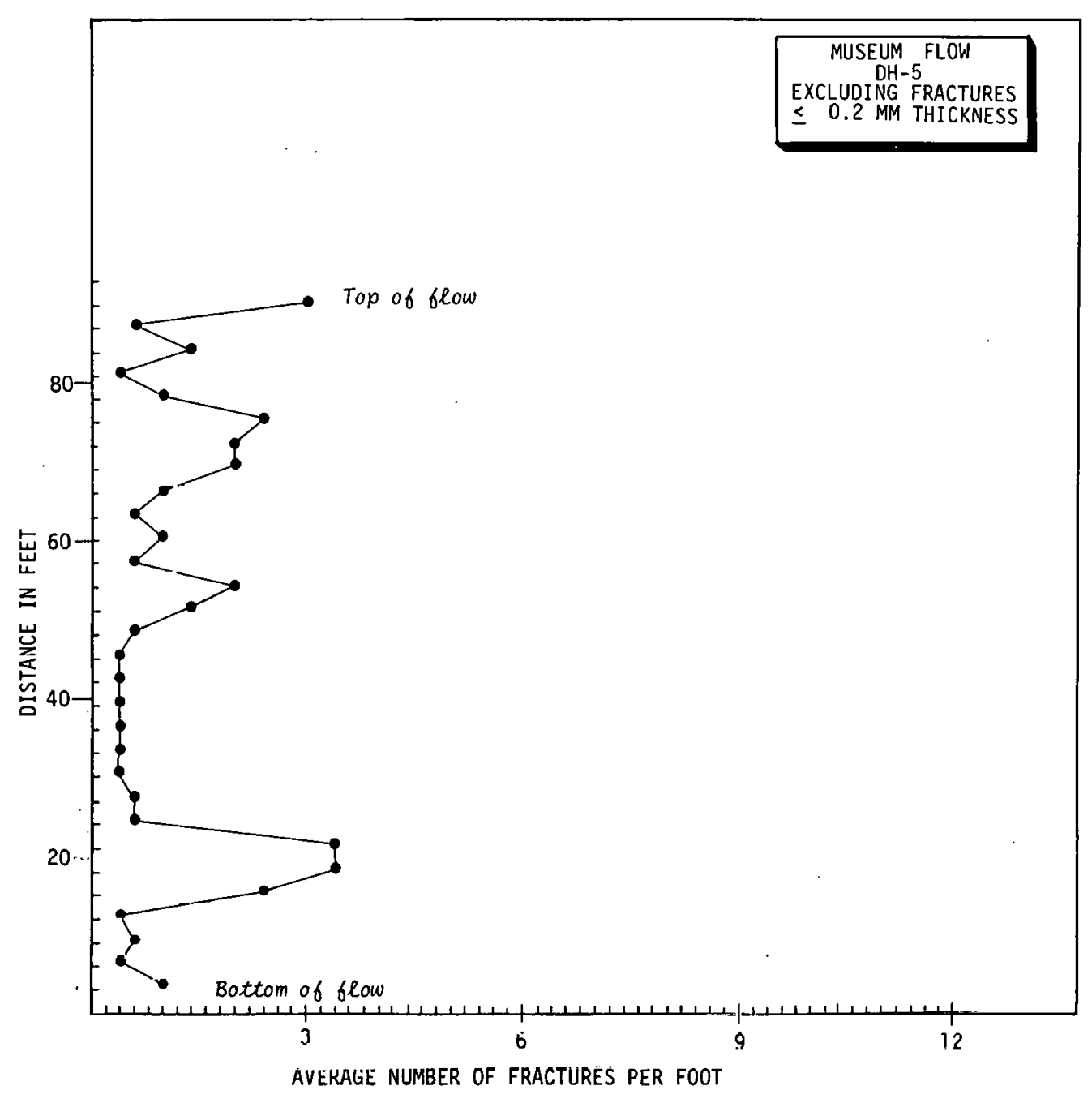

FIGURE 17-A

POSITION IN FLOW PLOTTED AGAINST AVERAGE NUMBER OF FRACTURES PER FOOT $>0.2$ MILLIMETER IN THICKNESS FOR THE MUSEUM FLOW FROM DH-5 


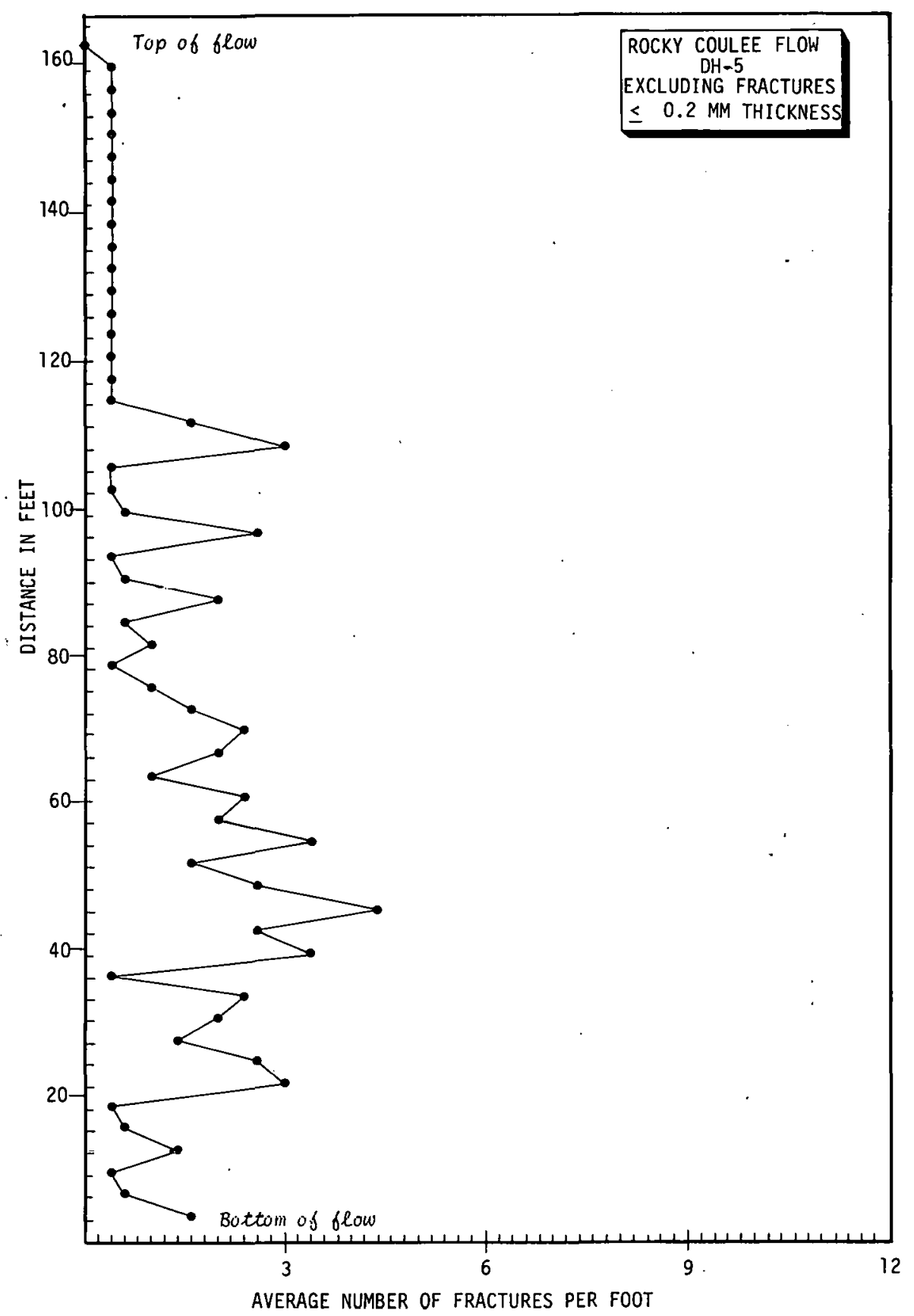

FIGURE 17-B

POSITION IN FLOW PLOTTED AGAINST AVERAGE NUMBER OF FRACTURES PER FOOT $>0.2$ MILLIMETER IN THICKNESS FOR THE ROCKY COULEE FLOW FROM DH-5 


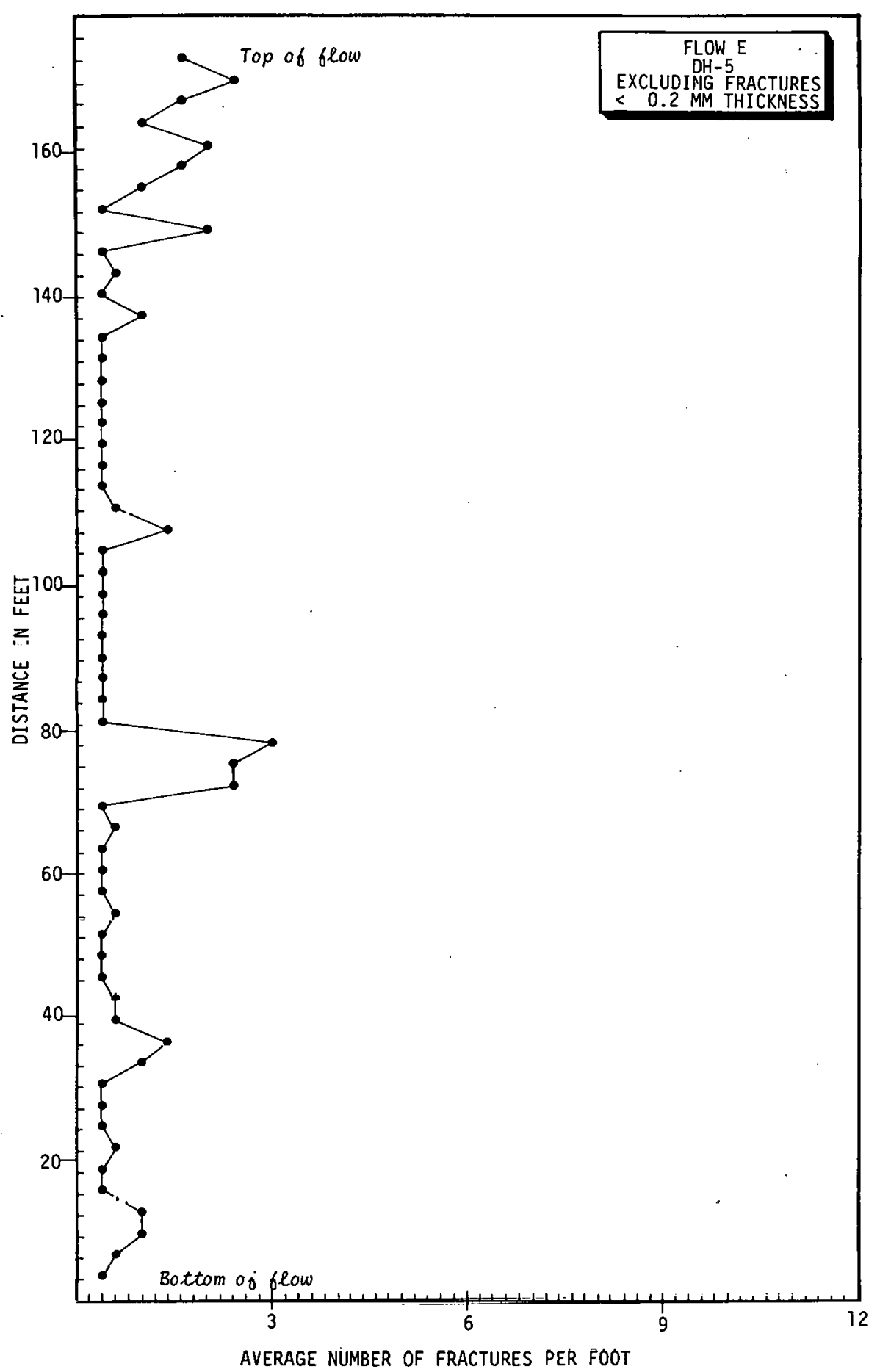

FIGURE 17-C

POSITION IN FLOW PLOTTED AGAINST AVERAGE NUMBER OF FRACTURES PER FOOT $>0.2$ MILLIMETER IN THICKNESS FOR FLOW E FROM DH-5 


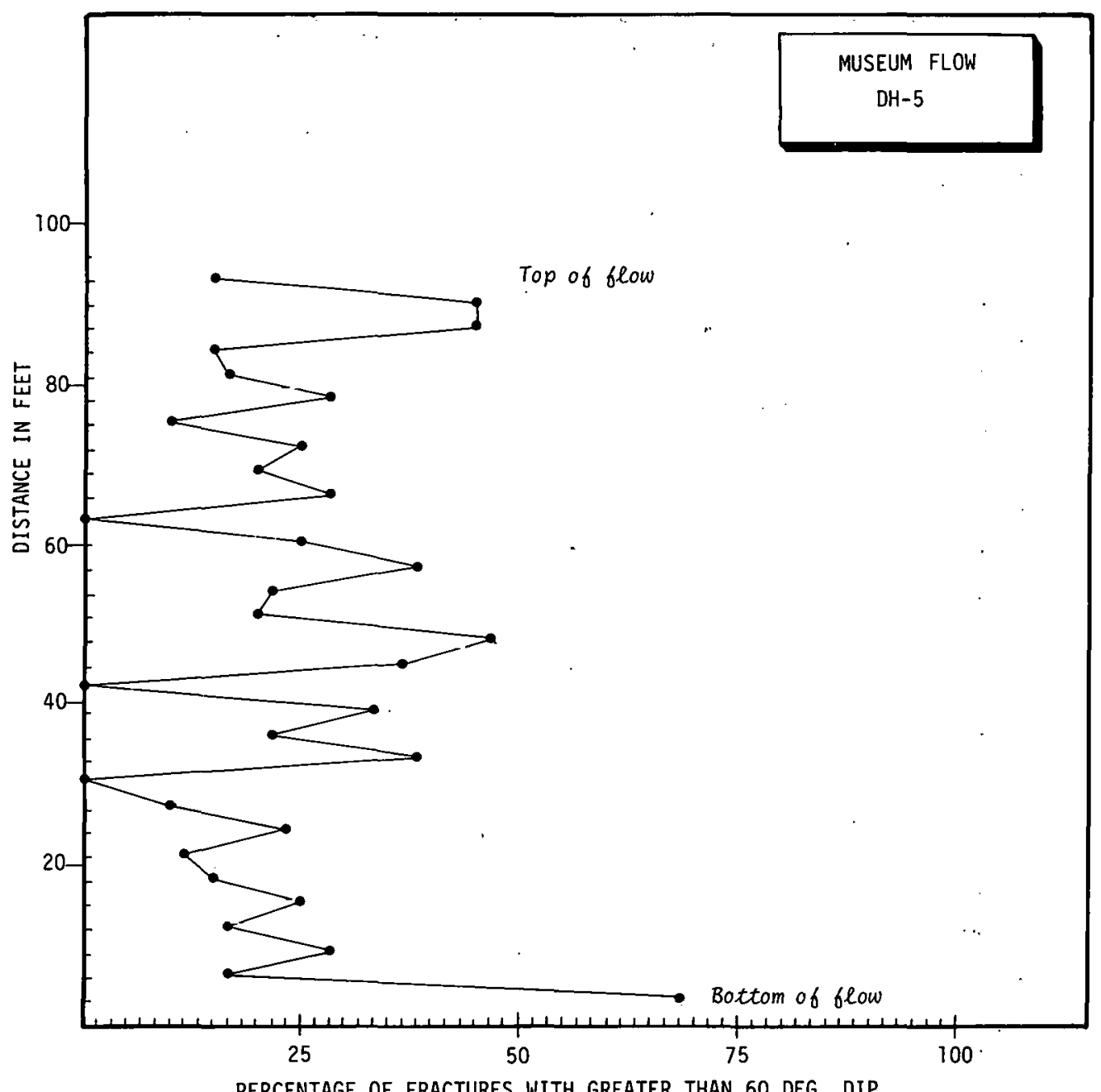

FIGURE 18-A

POSITION IN FLOW PLOTTED AGAINSTT PEERCENTAGE FRACTURES WITH GREATER THAN 60-DEGREE DIP FOR THE MUSEUM FLOW FROM DH-5 


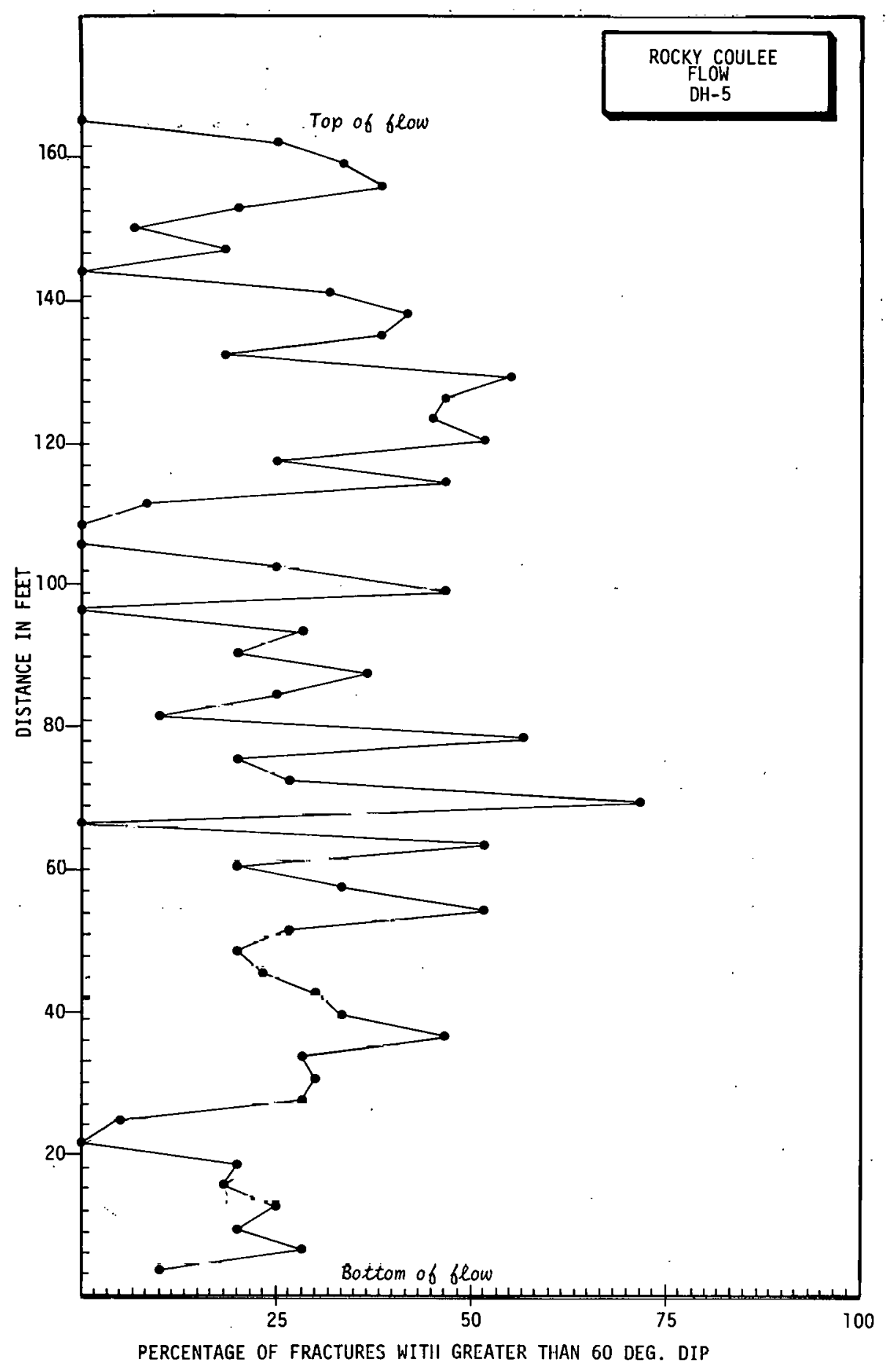

\section{FIGURE 18-B}

POSITION IN FLOW PLOTTED AGAINST PERCENTAGE FRACTURES WITH GREATER THAN 60-DEGREE DIP FOR THE ROCKY COULEE FLOW FROM DH-5 


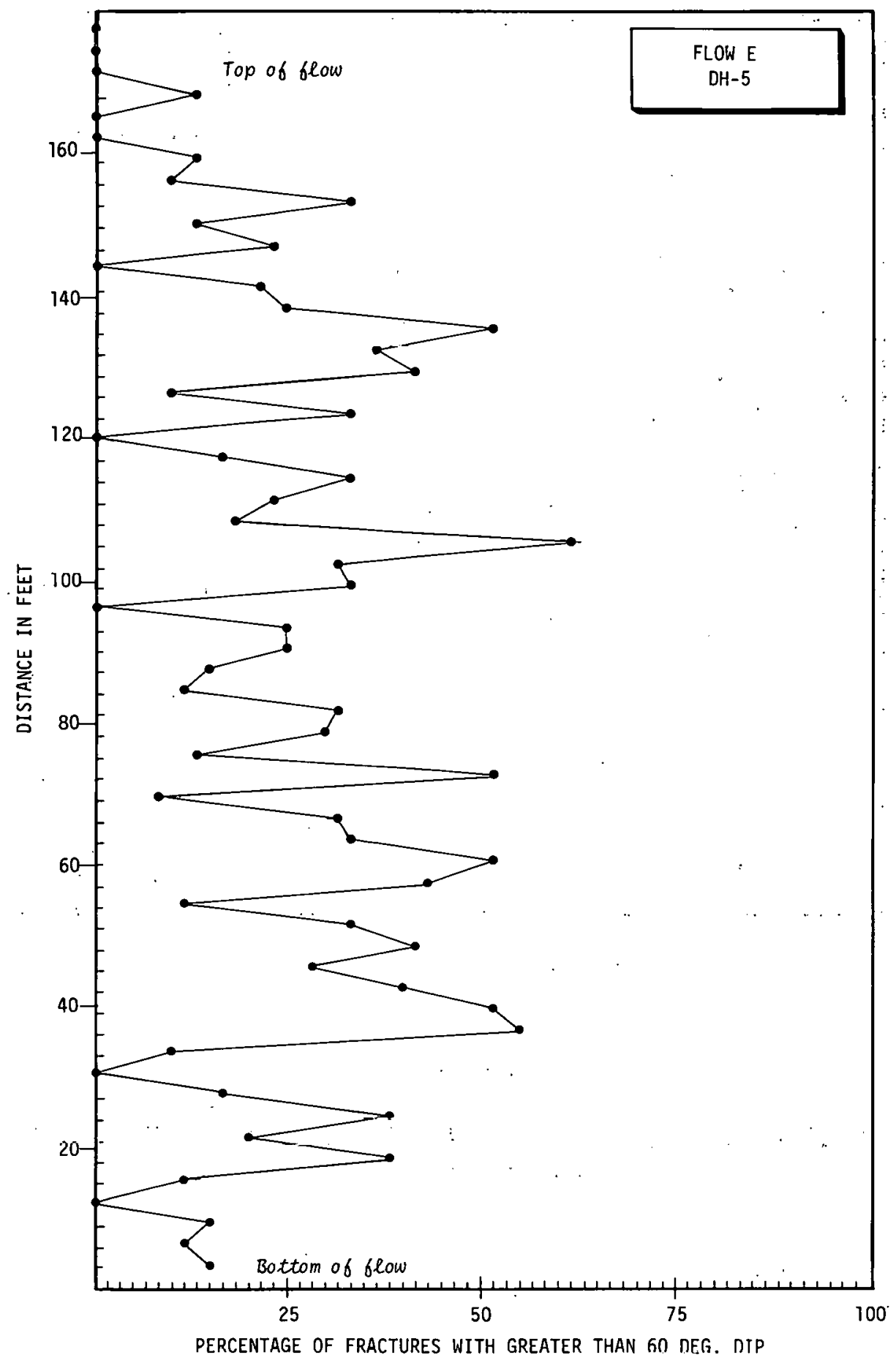

FIGURE 18-C

POSITION IN FLOW PLOTTED AGAINST PERCENTAGE FRACTURES WITH GREATER THAN 60-DEGREE DIP FOR FLOW E FROM DH-5 


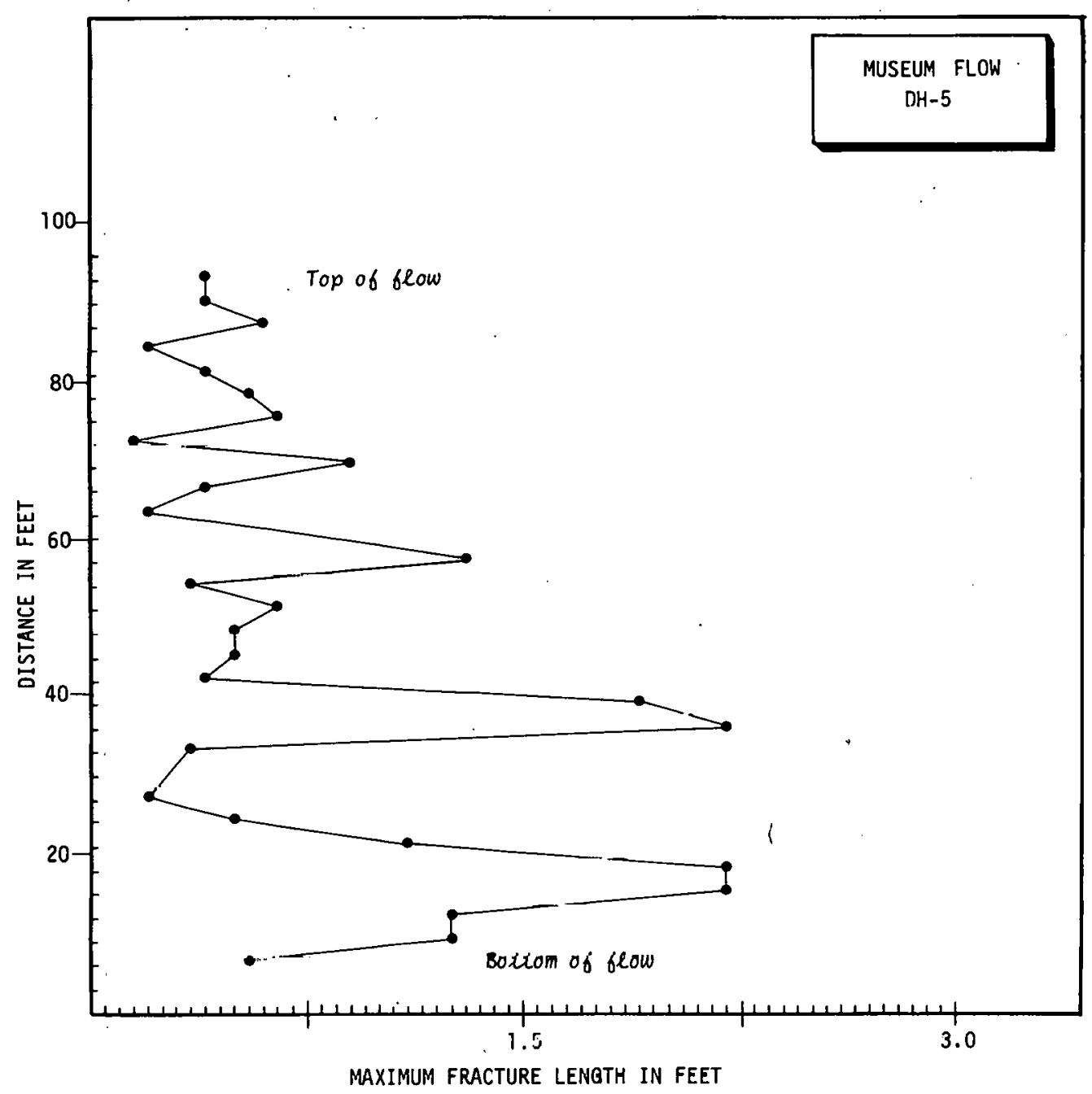

FIGURE 19-A

POSITION IN FLOW PLOTTED AGAINST MAXIMUM FRACTURE LENGTH FOR THE MUSEUM FLOW FROM DH-5 


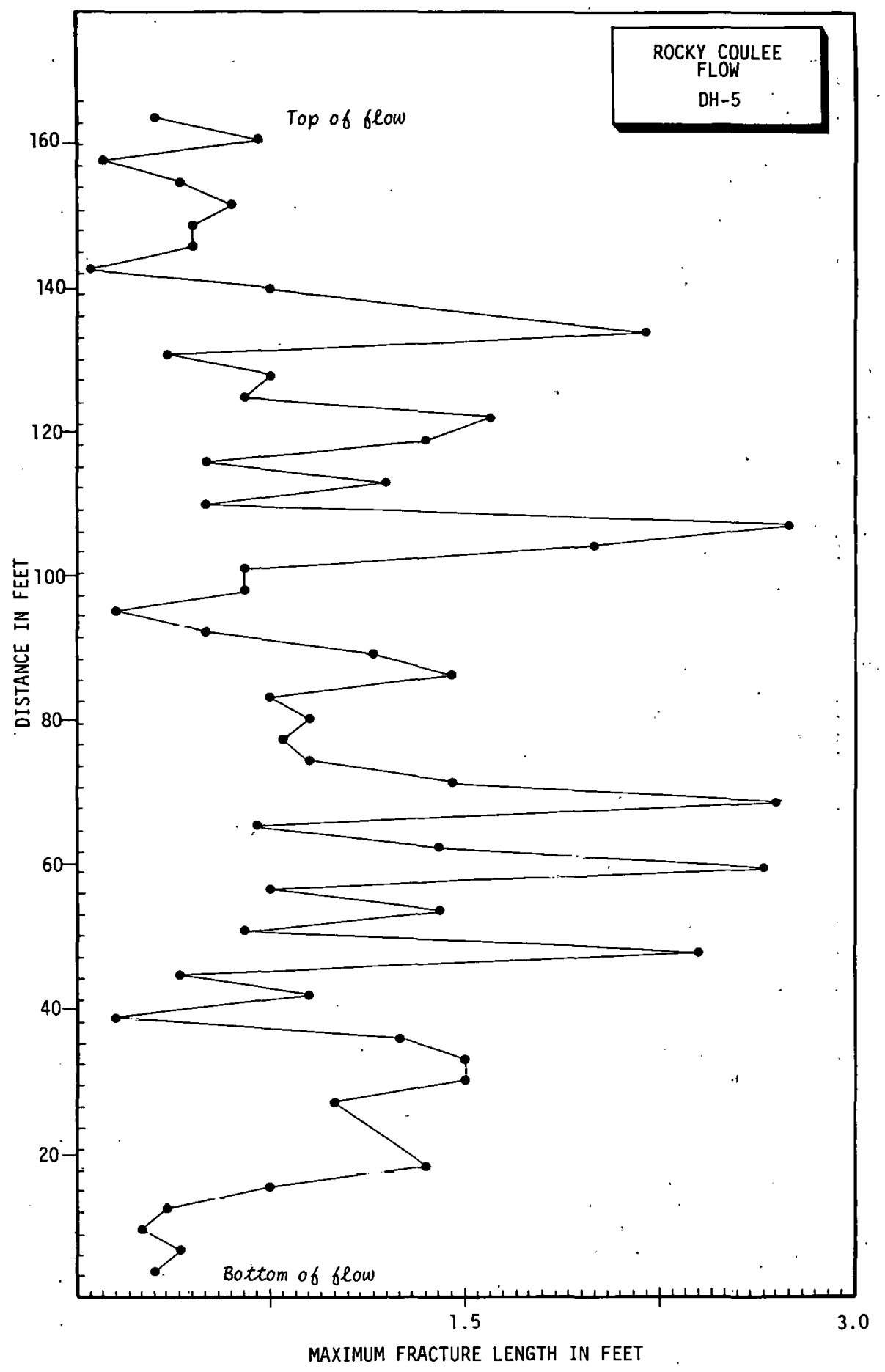

FI

FIGURE 19-B

POSITION IN FLOW PLOTTED AGAINST MAXIMUM. FRACTURE LENGTH FOR THE ROCKY COULEE FLOW FROM DH-5 


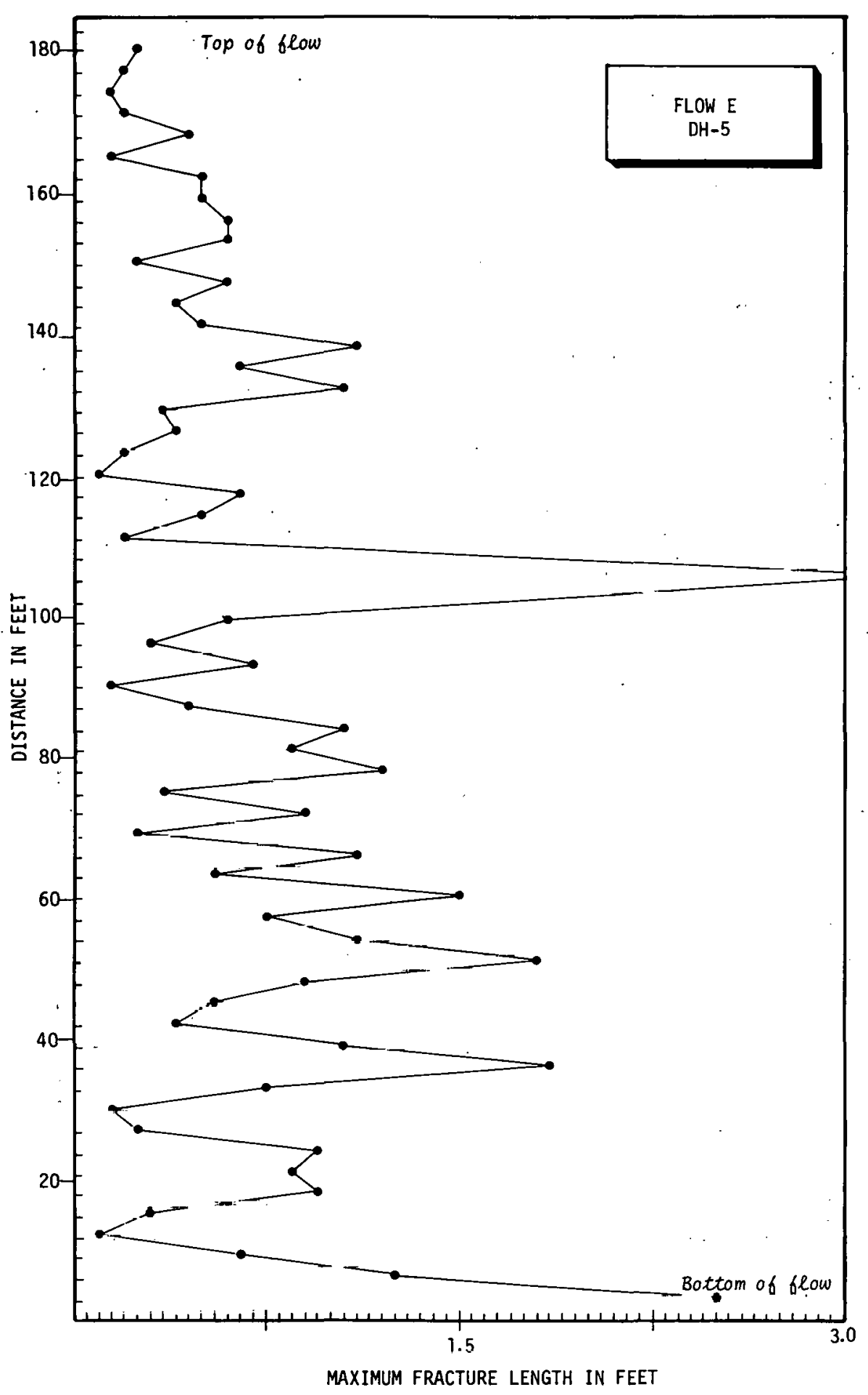

FIGURE 19-C

POSITION IN FLOW. PLOTTED AGAINST MAXIMUM FRACTURE LENGTH FOR FLOW E FROM DH-5 
at the surface. Figure 16 shows average number of fractures per foot in the Museum Flow (Figure 16-A), the Rocky Coulee Flow (Figure 16-B), and Flow $E$ (Figure 16-C). The only consistent feature appears to be a decrease in maximum fracture abundance near the base of each of the three flows. This feature is most distinct for Flow $E$; but, even for Flow $E$, scatter in the plotted points makes the position of the change in fracture abundance uncertain. It is possible, though, that the change does correspond to the contact between entablature and colonnade. For Figures $16-A$ and $16-B$, the scatter is so great that no such interpretation seems warranted. Furthermore, for this interpretation to hold for Flow $E$, it would have only 30 feet of colonnade. which is possible, but it seems unlikely.

Figures 17-A, 17-B, and 17-C correspond to Figures 16-A, 16-B, and 16-C, except that narrow ( $\leq 0.2-\mathrm{millimeter)}$ fractures have been excluded in an attempt to filter out secondary fractures and, thus, the figures show the distribution of primary fractures. This did not produce any pattern useful in distinguishing entablature from colonnade. Figure 17-B does suggest, however, that fractures in the upper part of the Rocky Coulee Flow are mostly narrow ones, but this information apparently does not relay any information about intraflow structures in the upper part of the Rocky Coulee Flow.

Another possible difference between intraflow structures is that the entablature may have a lower percentage of high-angle fractures. This was tested by plotting position in the flow versus percentage of total number of fractures with greater than a 60-degree dip (Figures 18-A, 18-B, and 18-C). These dlagrams shuw a yreal deal of scatter and no distinct pattern emerges. If anything, there tends to be a generally lower percentage of high-angle fractures toward the base of the flows. This is the opposite of what one would intuitively predict from examination of flows at the surface. A possible explanation is that dritl core "sampling" of fractures is significantly different from general perception of fractures at the surface at Sentinel Gap.

The length of fractures measured in core provide a measure of riaclure dip, since high-angle fractures will obviously transect a 
greater length. Figures 19-A, 19-B, and 19-C show the maximum fracture length plotted against depth for the three flows in DH-5. Again, no consistent, obvious pattern emerges that would identify intraflow structures.

\section{RESULTS FROM SURFACE MEASUREMENTS}

Plots of fracture abundance for data from surface exposures are shown in Figures 20-A, 20-B, and 20-C. The Museum Flow (Figure 20-A) shows a general increase in fracture abundance toward the top, which is consistent with its lack of an entablature and its crudely tapered columns.

The Rocky Coulee Flow (Figure 20-B) is more irregular in distribution of fractures toward the top, which is consistent with its lack of an entablature and its crudely tapered columns.

The Rocky Coulee Flow (Figure 20-B) is more irregular in distribution of fractures, which is reasonably consistent with its tiered character. Note, however, that it is difficult to interpret the actual details of the structures based on fracture abundance. Similar zones of high fracture abundance do occur in Figure $16-B$ and these may correspond to platy zones.

Fracture density for Flow E, however, shows the anticipated, abrupt change in fracture abundance at the entablature--colonnade contact. From the diagram, it is possible to ascertain that the change from entablature. to colonnade takes place in less than three feet; consistent with actual inspection of the contact. Furthermore, the fracture abundance in the entablature is always greater than that in the colonnade and this is, again, consistent with actual inspection of the two parts of the flows.

Percentage of fractures with greater than a 60-degree dip is plotted in Figures 21-A, 21-B, and 21-C. These data show a great deal of scatter and do not appear. to correlate in any consistent way with the known intraflow structures. Flow E (Figure 21-C) does show a general increase in high-angle fractures upward, but this may only reflect the greater number of fractures in the entablature. The gradational nature of this change precludes recognition of the entablature--colonnade contact. 


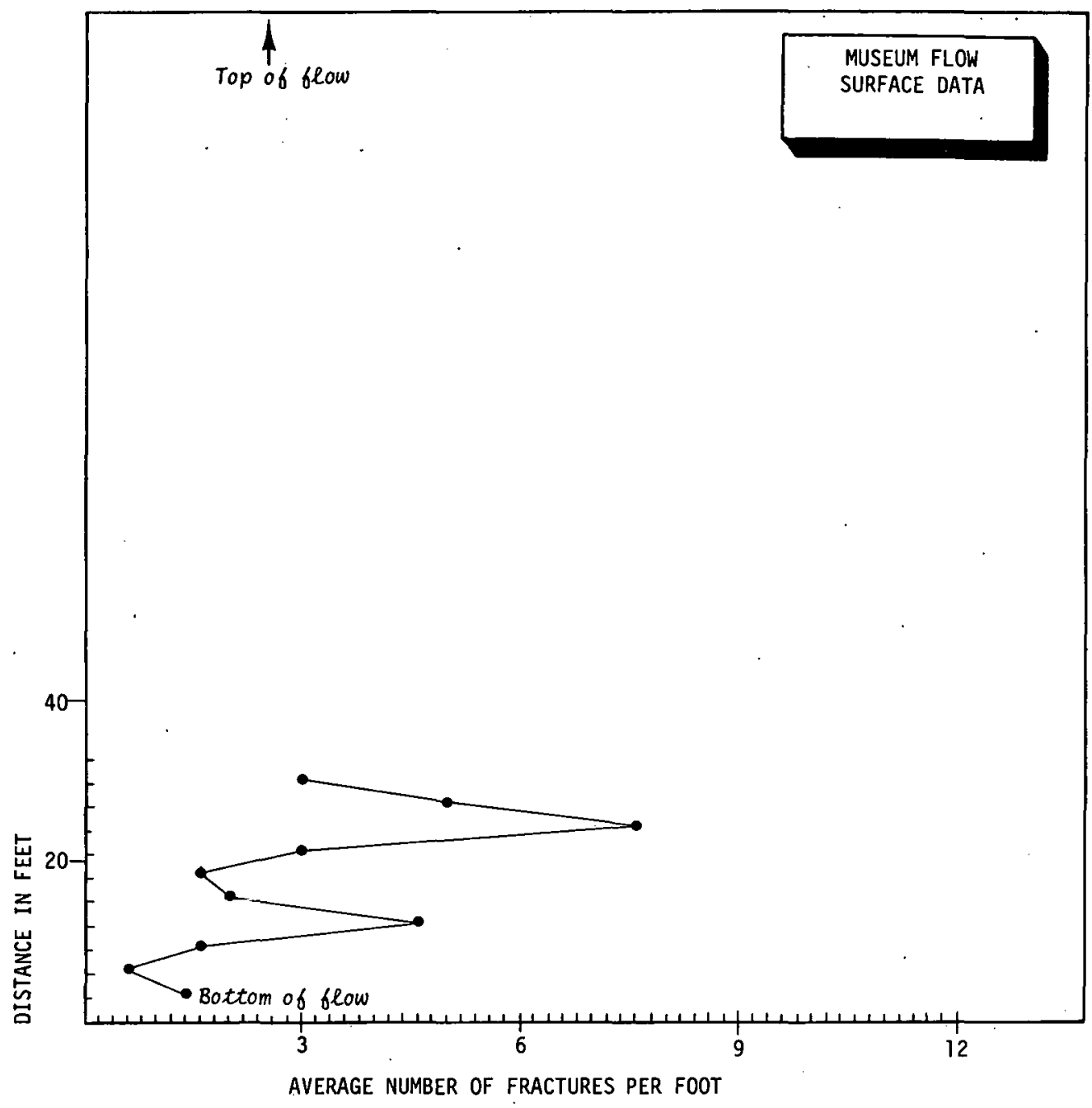

FIGURE 20-A

POSITION IN FLOW PLOTTED AGAINST AVERAGE NUMBER OF FRACTURES PER FOOT FOR THE MUSEUM FLOW FROM SURFACE EXPOSURES AT SENTINEL GAP 


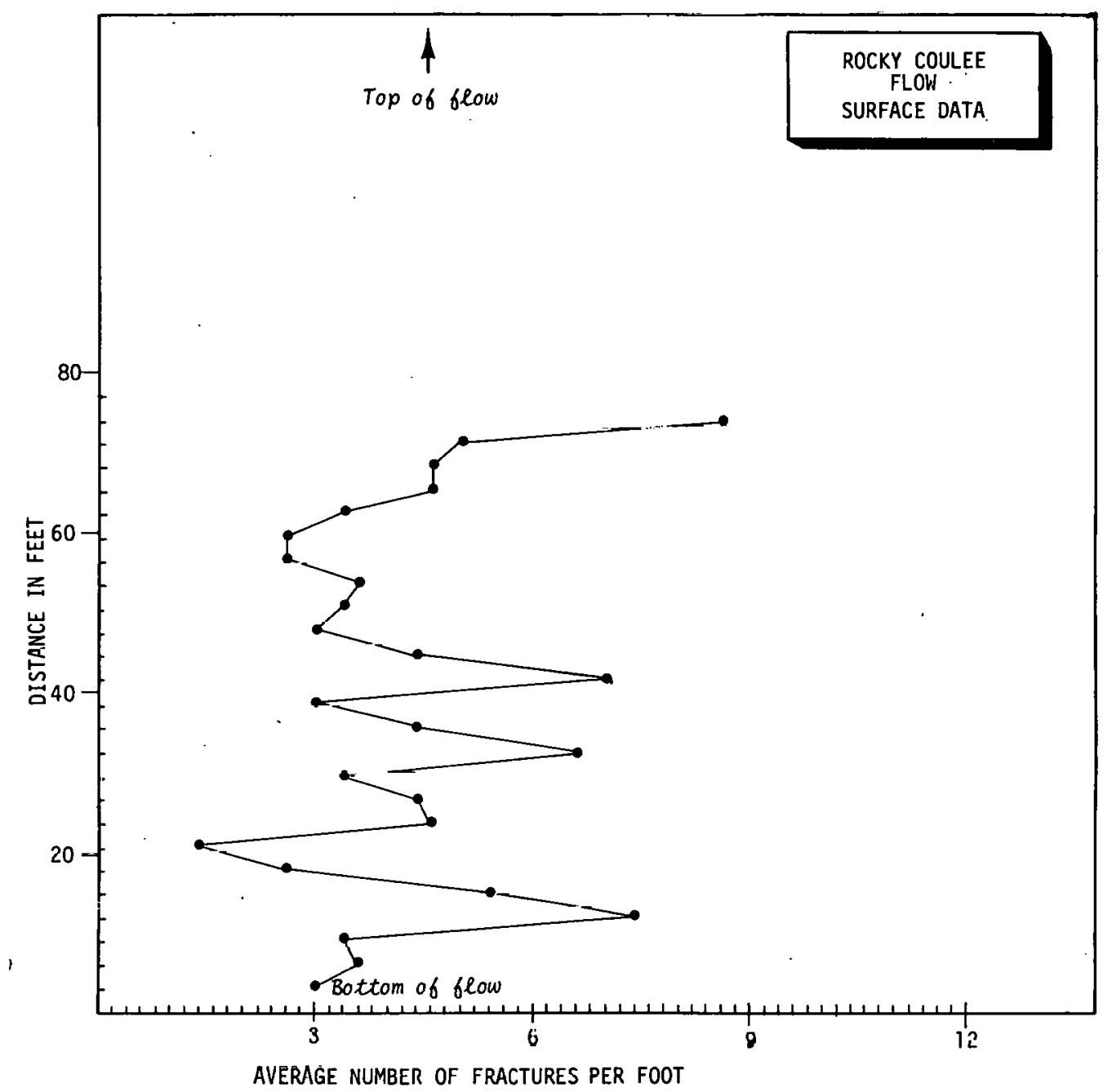

FIGURE 20-B

POSITION IN FLOW PLOTTED AGAINST AVERAGE NUMBER OF FRACTIIRFS PER FOUT FÖR IHE RUCKY COULEE FLOWW FROM SURFACE EXPOSURES AT SENTINEL GAP 


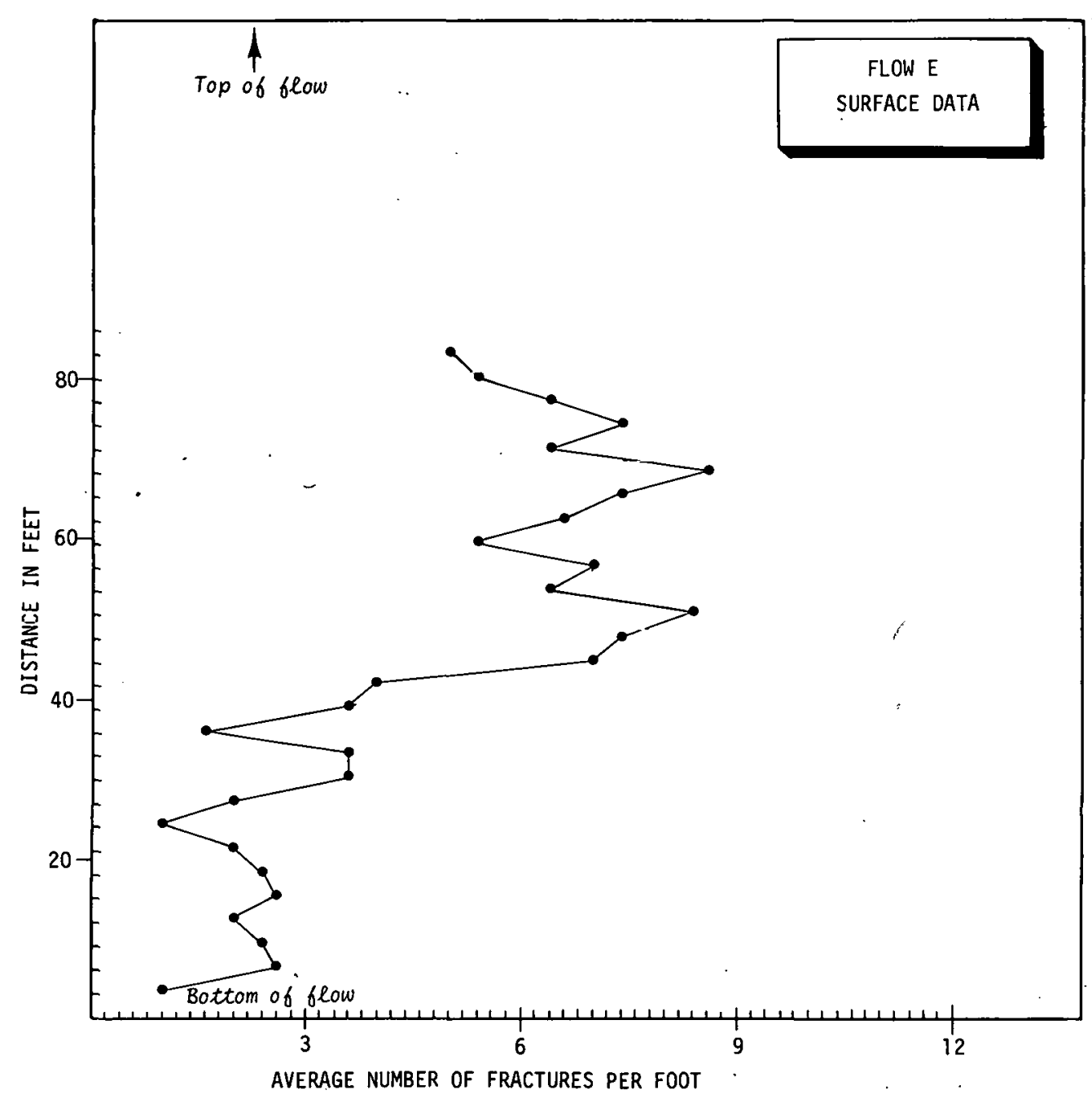

FIGURE 20-C

POSITION IN FLOW PLOTTED AGAINST AVERAGE NUMBER OF FRACTURES PER FOOT FOR FLOW E FROM. SURFACE EXPOSURES AT SENTINEL GAP 


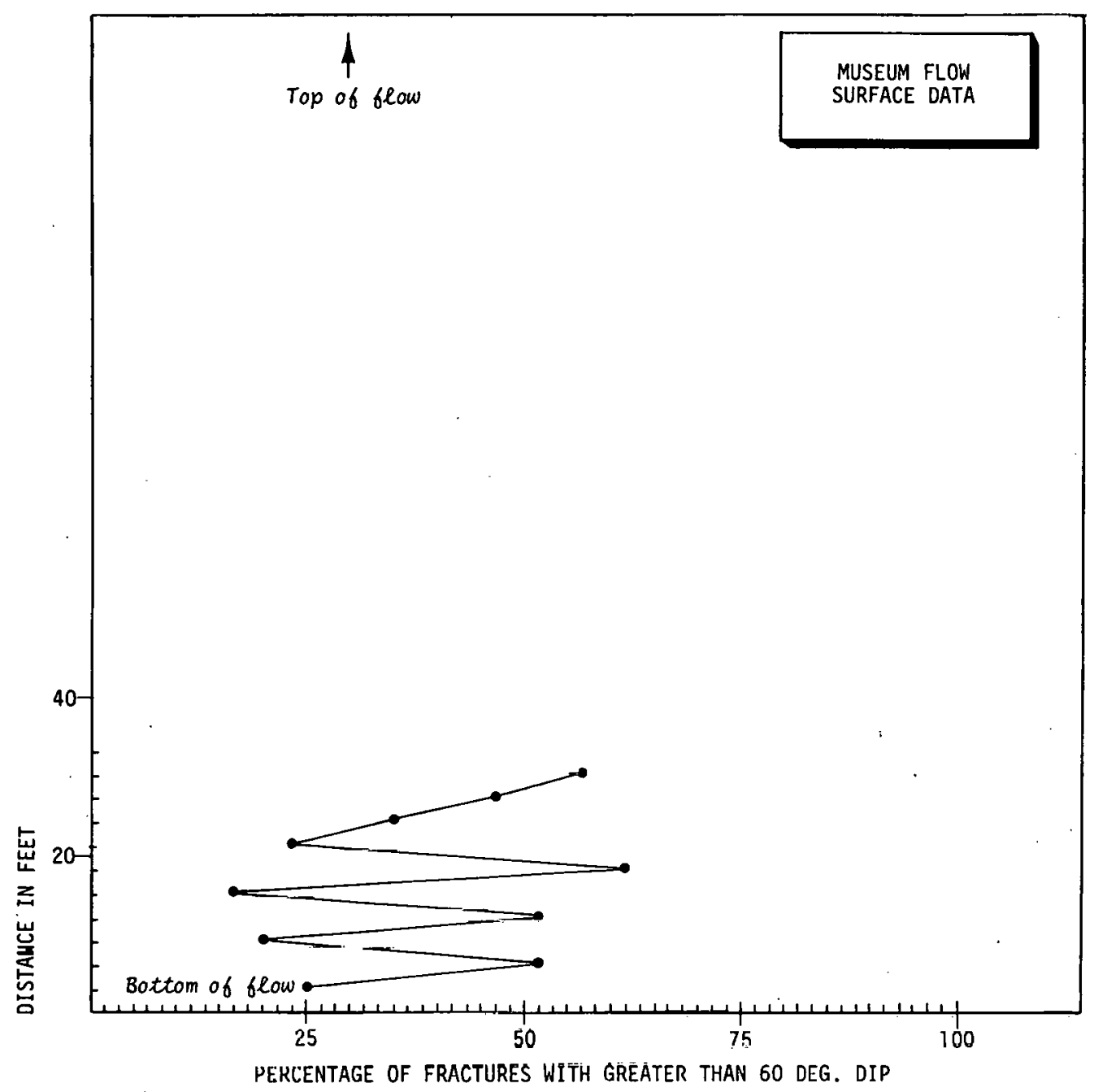

FIGURE 2T-A

POSITION IN FLOW PLOTTED AGAINST PERCENTAGE OF FRACTURES WITH GREATER THAN A 60-DEGREE DIP FOR THE MUSSEUM FLOW FROM SURFACE EXPOSURES AT SENTINEL GAP 


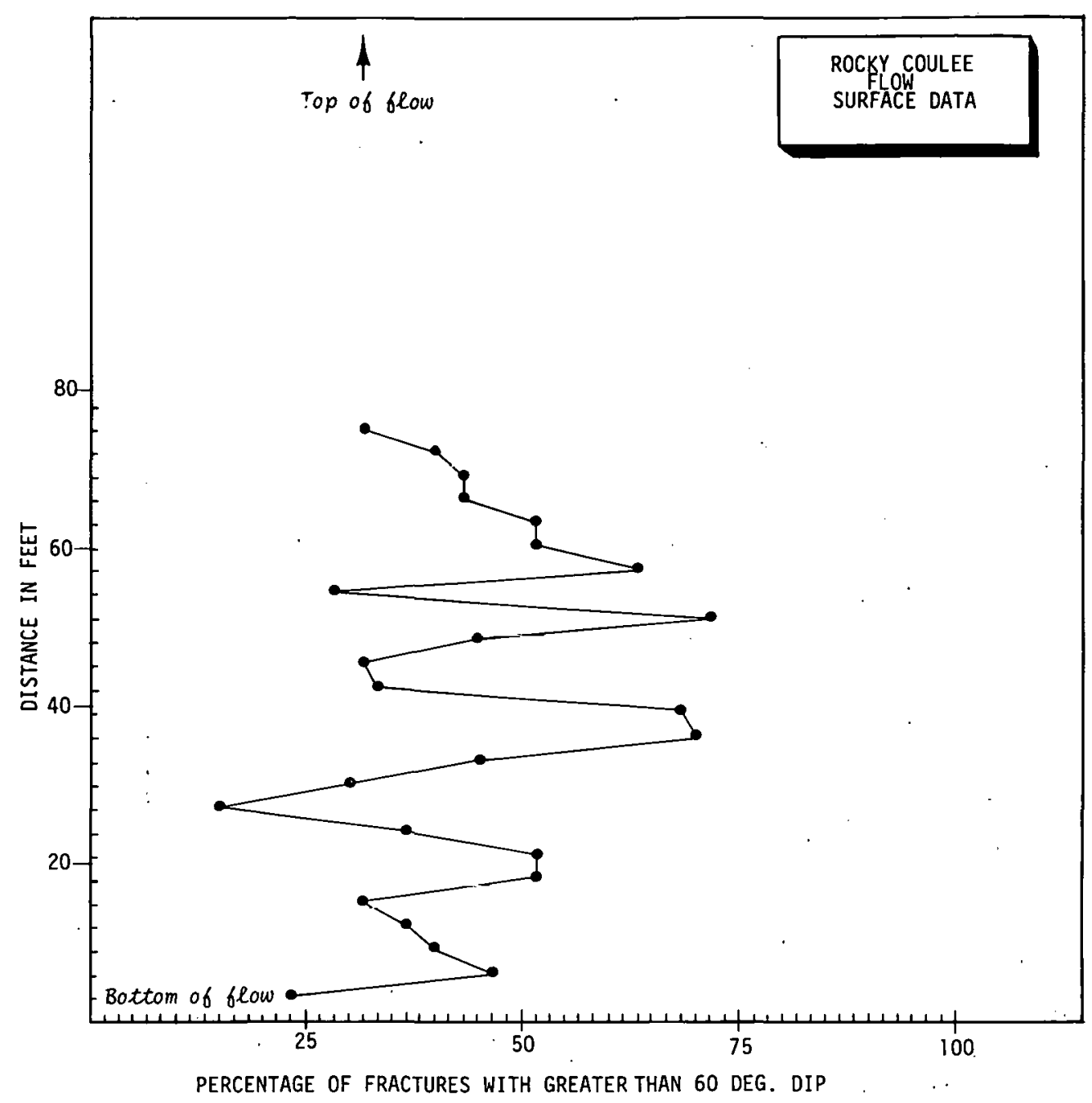

FIGURE 21-B

POSITION IN FLOW PLOTTED AGAINST PERCENTAGE OF FRACTURES WITH GREATER THAN A 60-DEGREE DIP FOR THE ROCKY COULEE FLOW FROM SURFACE EXPOSURES AT SENTINNEL GAP 


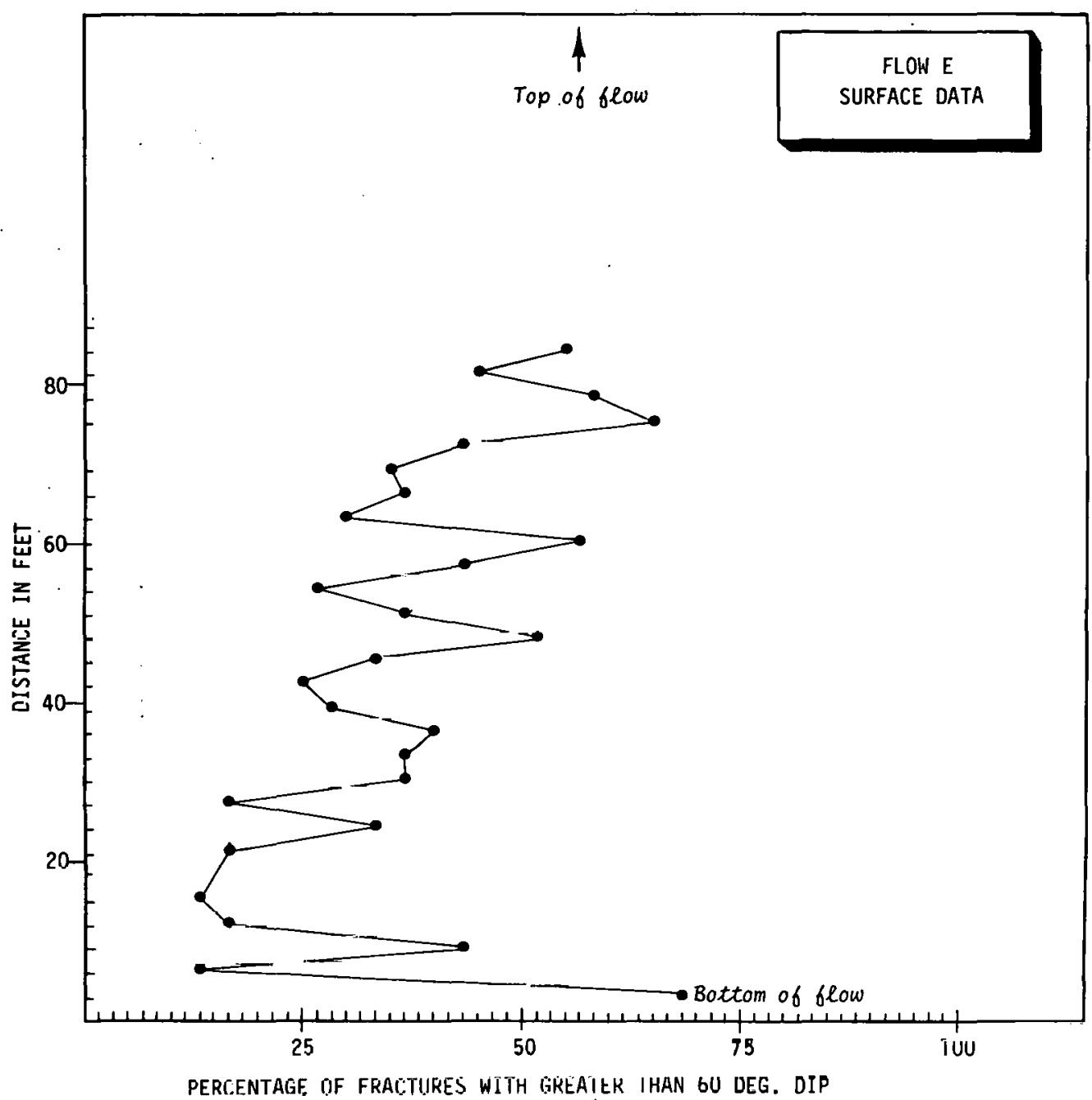

FIGURE 21-C

POSITION IN FLOW PLOTTED AGAINST PERCENTAGE OF FRACTURES

WITH GREATER THAN A 60-DEGREE DIP FOR. FLOW E FROM SURFACE EXPOSURES AT SENTINFI GAP 


\section{CORRELATION OF BASALT TEXTURES WITH INTRAFLOW STRUCTURES}

Petrographic observations indicate a strong correlation between certain basalt textures and intraflow structures. These correlations hold primarily within a given flow, requiring that they be based on comparison of textures of samples within the same flow rather than an absolute comparison between flows. Thus, a determination of intraflow structures cannot be based on observation of one sample.

Two textural features correlate with a sharp transition from entablature to colonnade:

1. A marked change in volume percent glass; and,

2. An equally marked change in the abundance and size of crystallites in that glass.

In addition to clearly marking the position of a sharp break between entablature and colonnade, these two features also seem to correlate in a general way, within a given flow, with column diameter such that both the upper colonnade and areas of "secondary" colonnade within the entablature are distinguished by lower glass content and fewer crystallites in the glass. The highest glass contents are found in the most hackly jointed parts of a Type 3 flow. Figures 22-A, 22-B, 22-C, 22-D, 22-E, and 22-F, are a set of photomicrographs showing the textural differences between two samples on either side of the entablature (Figures 22-A, 22-C, and $22-E$ ), colonnade (Figures 22-B, 22-D, and 22-F) contact. It is important to emphasize that the exact change in percentage of glass across the entablature--colonnade contact is different from one flow to another and the exact texture of the glass varies considerably. However, in the five cases examined in detail, the sense of change in glass content is always the same (increasing--going from the colonnade to the entablature) and the textural change is so marked as to be unmistakable in a series of spatially related thin sections. A typical example of the difference in glass textures is shown in Figures 23-A and 23-B.

Flows such as the Museum Flow, which have a very poorly developed entablature, are generdly coarser grained and have a lower glass rnntent on the average than, say, Type 3 flows. Where there is a poorly 


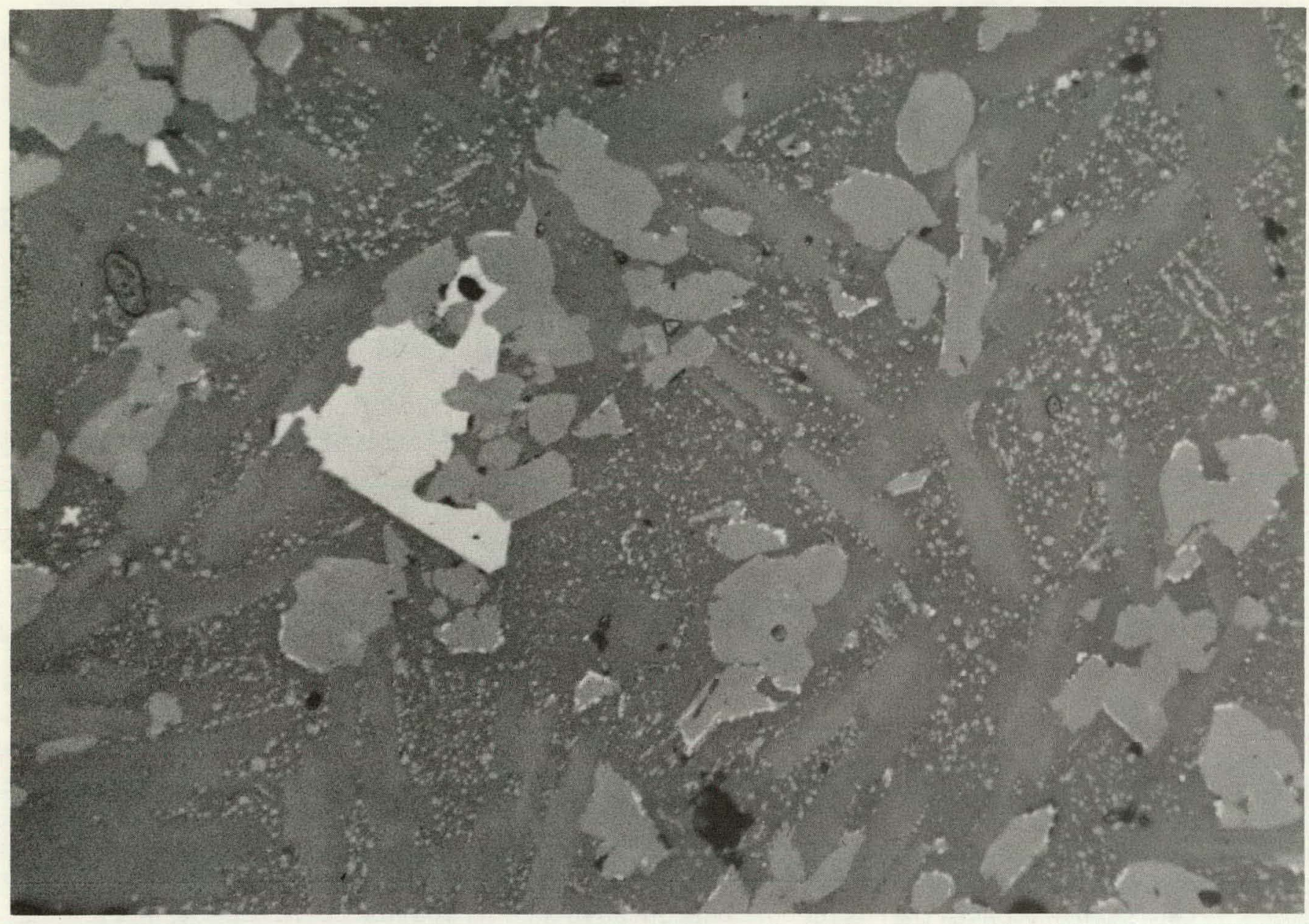

FIGURE 22-A

PHOTOMICROGRAPHS COMPARING TEXTURES OF ENTABLATURE AND COLONNADE OF THE UMTANUM TLOW AT UMTANUM RIDGE

ENTABLATURE, REFLECTED LIGIIT (C2249)

(Compare glass texture with that of Figure 22-B; width of the photomicrograph is 0.6 millimeter.) 


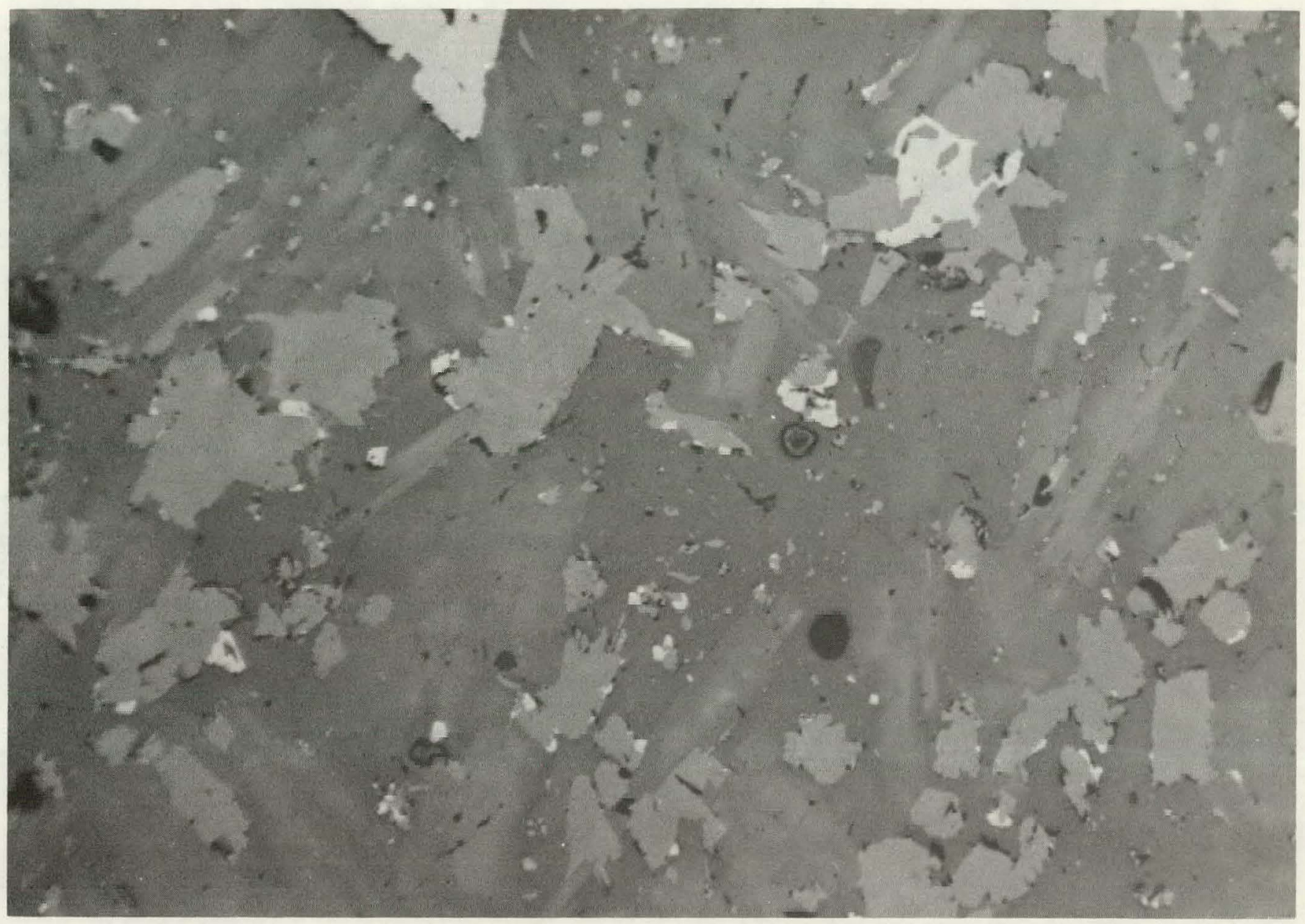

FIGURE 22-B

PHOTOMICROGRAPHS COMPARING TEXTURES OF ENTABLATURE AND COLONNADE OF THE UMTANUM FLOW AT UMTANUM RIDGE

$$
\text { COLONNADE, REFLECTED LIGHT (C2250) }
$$

(Compare glass texture with that of Figure 22-A; width of the photomicrograph is $0.6 \mathrm{mi} 11$ imeter.) 


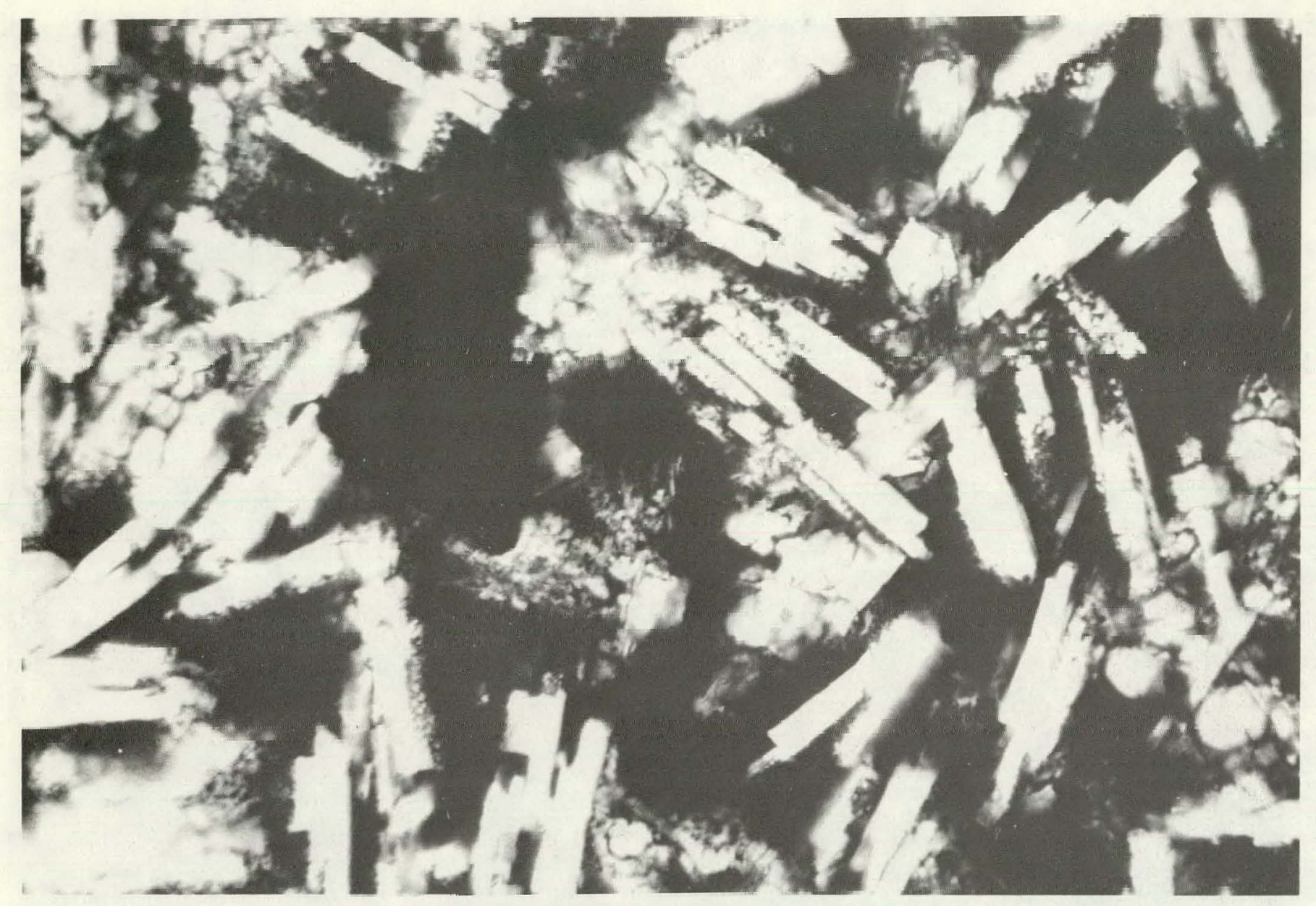

TIGURE 22-C

PHOTOMICROGRAPHS COMPARING TEXTURES OF ENTABLATURE AND COLONNADE OF THE UMTANUM FLOW AT UMTANUM RIDGE

ENTABLATURE, PLANF POI ARIZED TRANSMITTED LIGHT (C2249)

(Glass content 255 percent; width of photomicrograph is 0.6 millimeter.) 


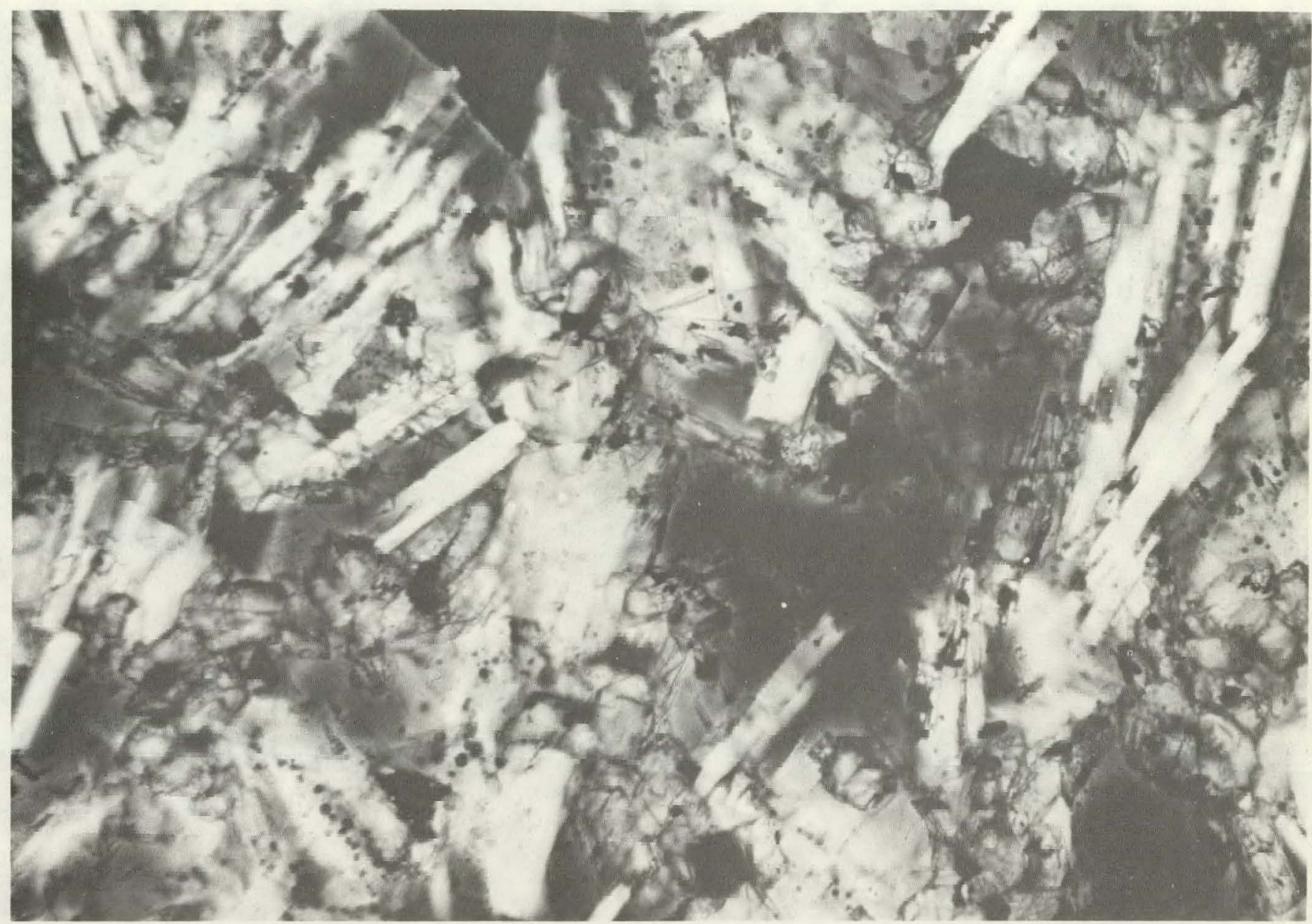

FIGIJRF 22-D

PHOTOMICROGRAPHS COMPARING TEXTURES OF ENTABLATURE AND COLONNADE OF THE UMTANUM FLOW AT UMTANUM RIDGE COLONNADE, PLANE POLARIZED TRANSMITTED LIGHT (C2250)

(Glass content $\sim 35$ percent; width of the photomicrograph is 0.6 millimeter.) 


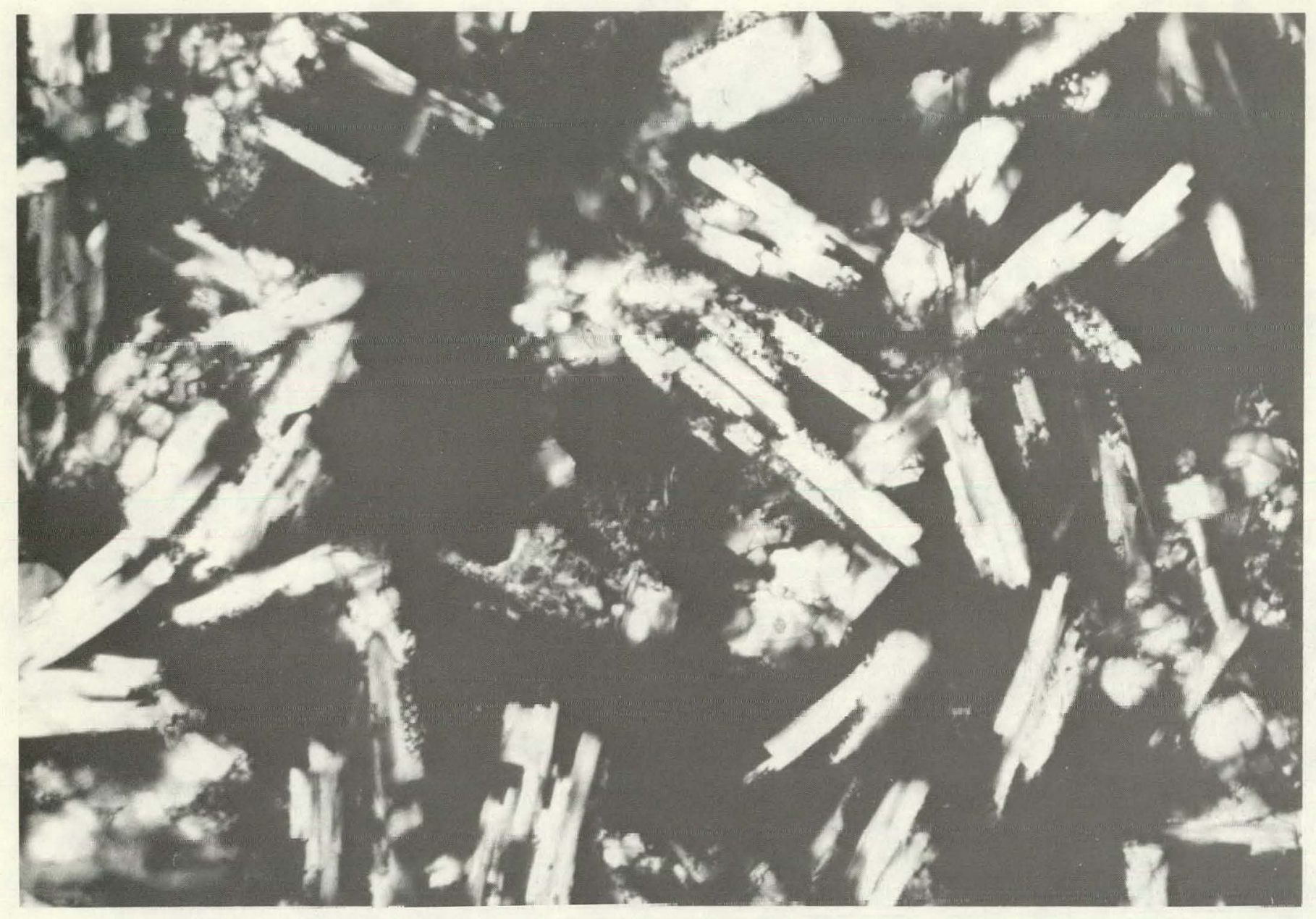

FIGURE '2'-E

PHOTOMICROGRAPHS COMPARING TEXTURES OF ENTABLATURE AND COLONNADE OГ TIIL UMTANUM FLOW AT UMTANUM RIUGL

ENTABLATURE, CROSSED NICOLS (C2249)

(Width of the photomicrograph is about 0.6 millimeter.) 


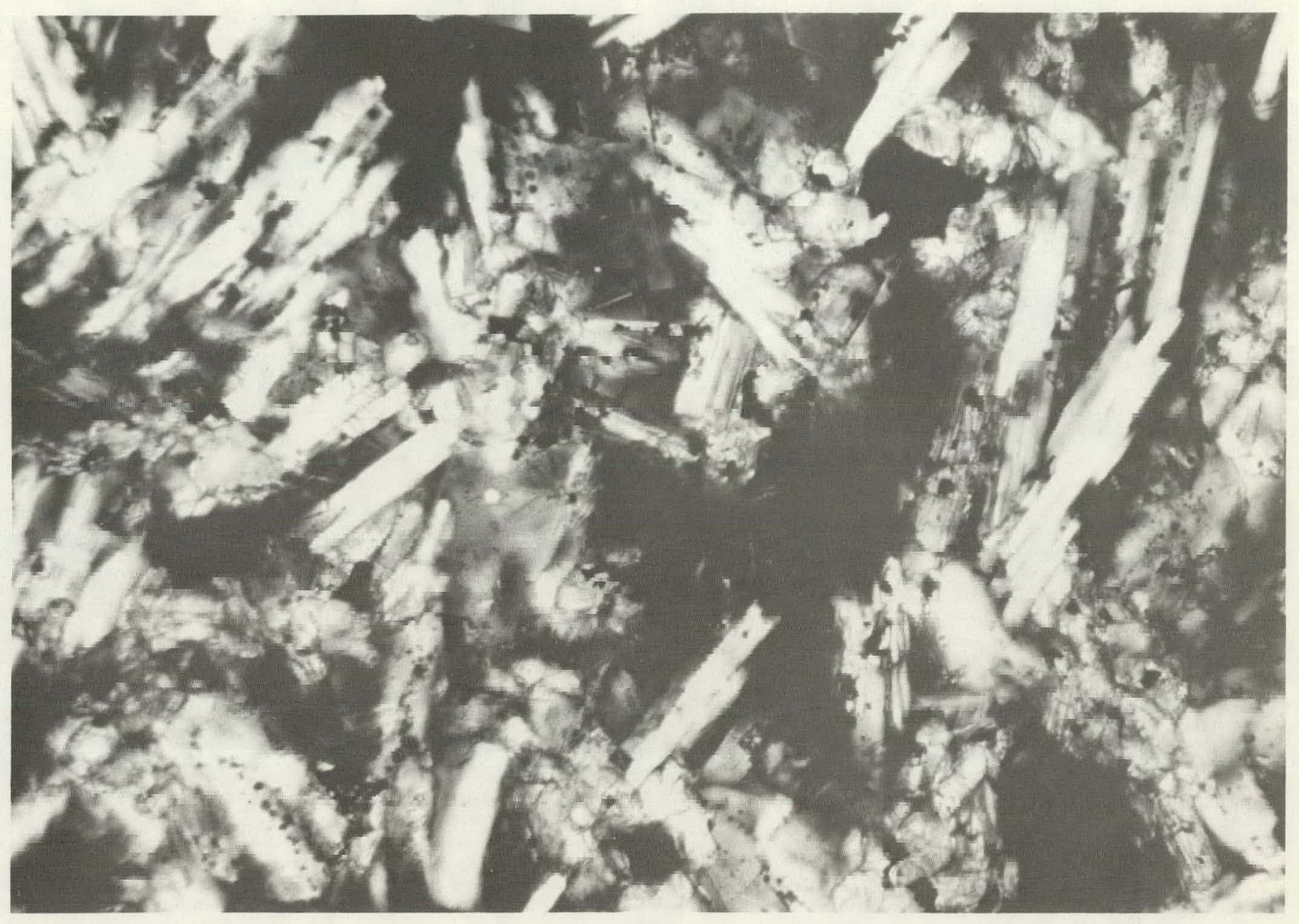

FIGURE 2'2-F

PHOTOMICROGRAPHS COMPARING TEXTURES OF ENTABLATURE AND COLONNADE OF THE UMTANUM FLOW AT UMTANUM RIDGE

COLONNADE, CROSSED NICOLS (C2250)

(Width of the photomicrograph is about 0.6 millimeter.) 


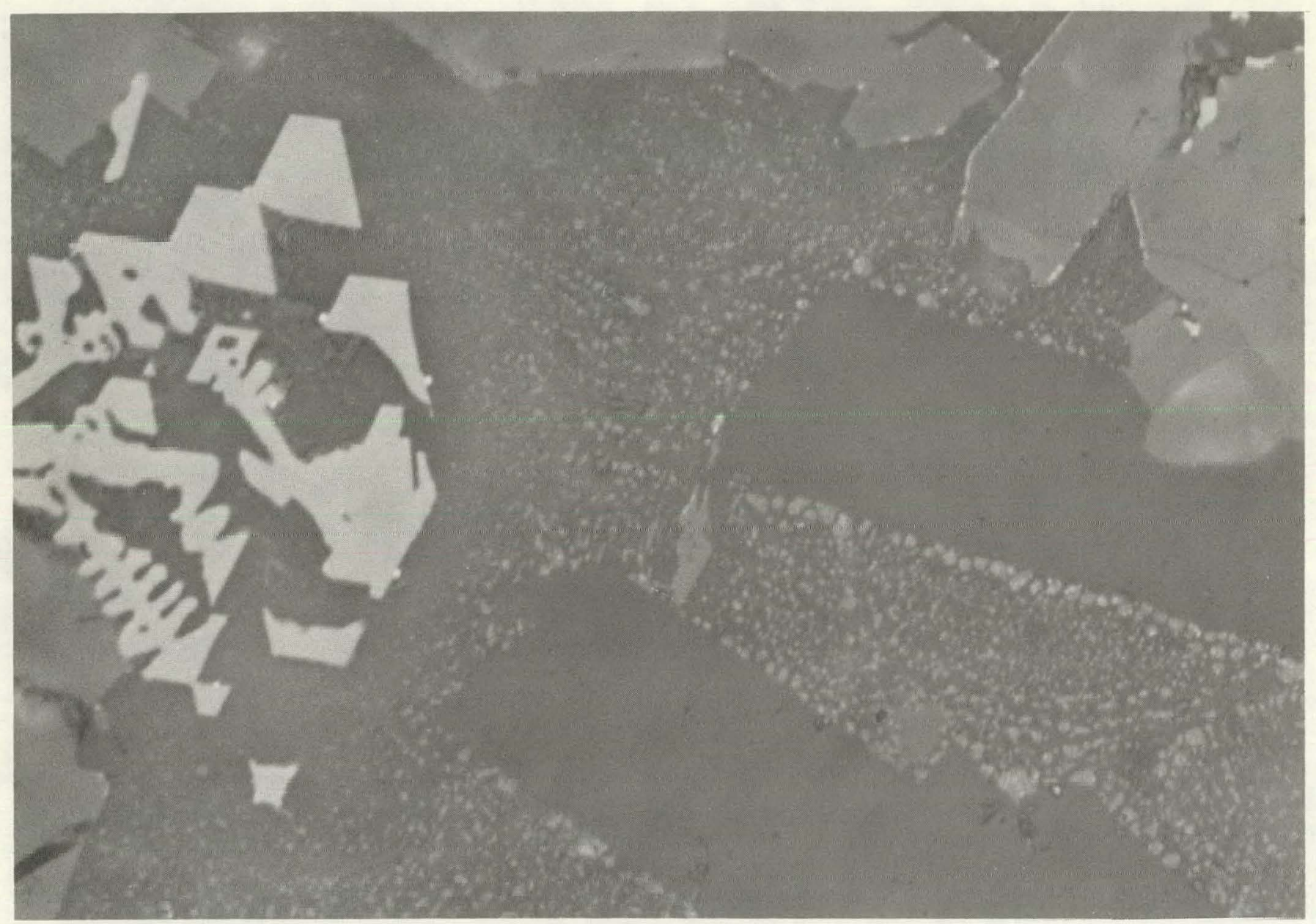

FIGURE 23-A

PHOTOMICROGRAPHS COMPARING GLASS TN ENTABLATURE ANU COLUNNADE FROM FLOW E, SENTINEL GAP

ENIABLATURE, REFLECTED LIGHT

(Inclusion-charged glass [C4295]; width of the photomicrograph is 0.2 millimeter.) 


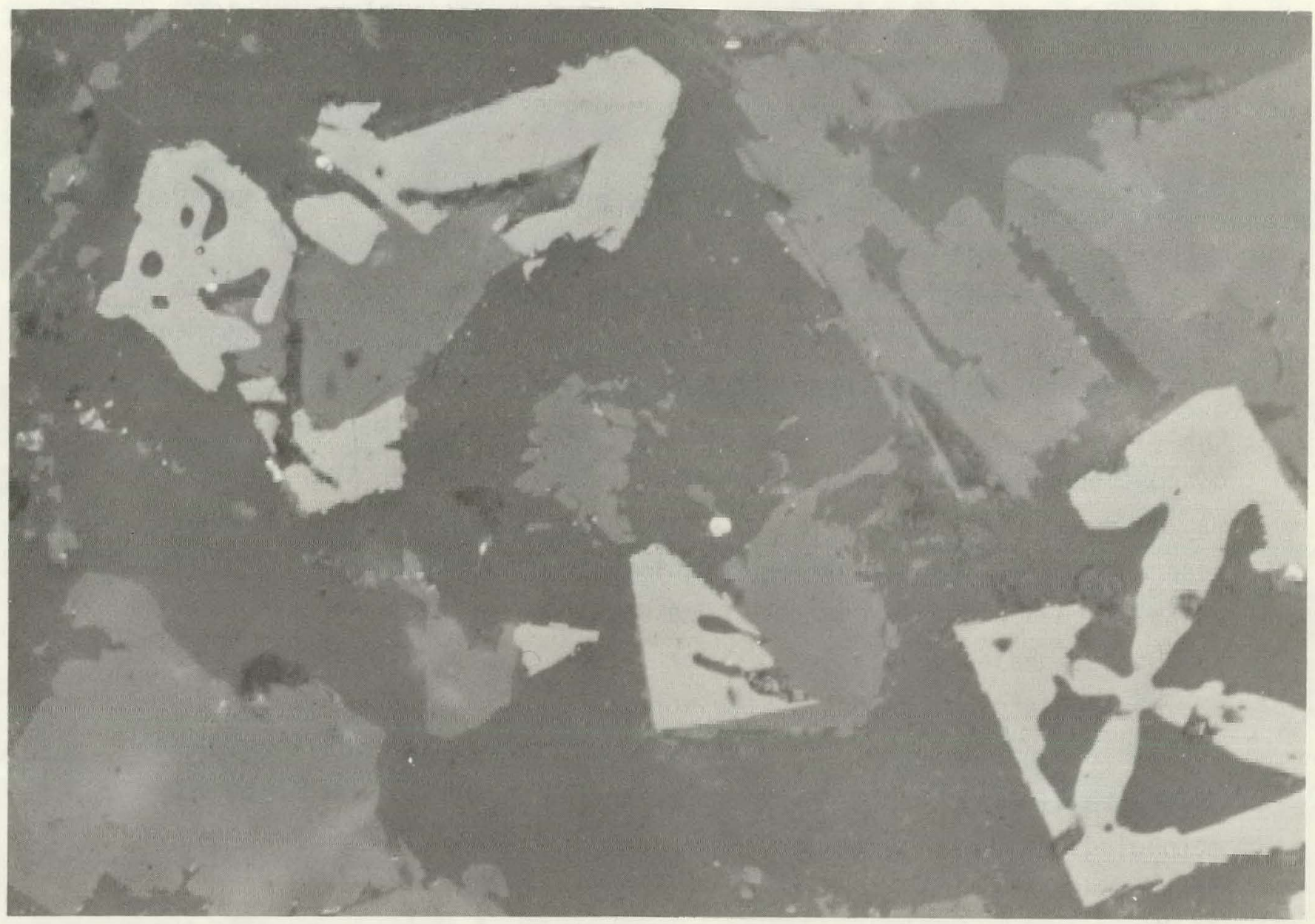

FIGURE 23-B

PHOTOMICROGRAPHS COMPARING GLASS IN ENTABLATURE

AND COLONNADE FROM FLOW E, SENTINEL GAP

COLONNADE, REFLECTED LIGHT

(Note the virtual absence of inclusions in glass [dark grey] [C4296]; notice also the subtle differences in morphology of the FeTi uxide phases [1ightest color] between Figures 23-A and $23-B$. The width of the photomicrograph is 0.20 millimeter.) 
developed zone of smaller columns at the top of these flows, they do show a textural change to greater percentage of tachylitic glass. This textural change is apparently gradual where the change in intraf low structure is gradual and corresponds in degree to the extent of change in average column diameter.

Morphology and grain size of opaque phases vary as a function of position in a flow. The opaque grains show a particularly wide range in size and shape which are a sensitive response to physical conditions under which a given part of the flow crystallized. In some flows, the morpholugy of opaques appears to vary continuously across the entablature--rononnade contact, but, in others, there may be a discontinuous change across the contact. In each case, the opaque grains may be responding to a different set of physical cundiliuns than those responsible for the change in percentage and texture of glass across the entablature--colonnade contact. One way this could happen would be if the opaque phases crystallized prior to the crystallites in the glass.

Plagioclase and clinopyroxene morphologies also change slightly through a flow, but these changes appear to be related more to the degree of crystallization rather than a fundamental difference in basic morphology related to, say, cooling rate (Lofgren, 1974). That is, the final morphology and texture of plagioclase in the entablature of a flow probably would be indistinguishable from that. of the colonnade if the entablature had crystallized more completely.

\section{DISCUSSION OF RFSIIITS}

Textural data from a series of thin sections from conre can arcurately define the contact between entablature and colonnade when it is present and, with additional refinement, can provide quantitative information on fracture abundance. The relationship between fracture abundance and basalt textures occurs because the fracturing responds to the mechanical properties of the rock. The mechanical properties of the rock are, in turn, controlled by the rock texture; in particular, the glass content, 
because glass has substantially different mechanical properties than crystalline materials. A consequence of this is that the texture , actually provides information on the mechanical condition (average fracture abundance) of a much wider area surrounding the drill core than do the fractures themselves.

The difficulty in interpreting the textures comes in understanding why they are distributed so differently in the different types of flows. Clearly, factors other than cooling rate alone are involved and possible interrelationships between intraflow structures, bulk chemistry, and volatile content need to be investigated if we are to fully understand intraf low structures.

The fracture data from surface flows are largely consistent with observable intraflow structures, but the fracture data from drill core do not appear to reflect actual intraflow structures.

Possible explanations for this range from the possibility that multiple flows are involved to lateral variation in intraflow structure types. In addition, the technique of fracture logging in core may be limited by the core diameter that is small compared to the spacing of fractures defining the major intraflow structures, or intraf low structures in surface outcrop may be partly a result of unloading, such that a densely fractured entablature at the surface is less so in the subsurface.

It seems likely that the flows are, in fact, physically continuous, especially in the case of the Rocky Coulee and Flow E, since they are thick flows that must be fairly widespread. Lateral change in intraflow structures is perhaps mure jrobable, but radical changes in the fundamental character can be argued against on chemical grounds; that is, among high-Mg Grande Ronde flows there are slight but distinct chemical differences between flows that have a well-developed entablature and those that do not. These chemical differences appear to be related to intraflow structures that develop, suggesting that if a flow like Flow $E$ has consistent chemistry it will consistently have a well-developed entablature. This argument cannot rule out the possibility that a flow 
like Flow $E$ might grade into a flow with tiered intraflow structure. The question remains as to whether or not we11-developed entablatures are indeed characteristic of certain flows over their entire areal extent, and, until this is resolved, lateral variations from one type of flow to another remain a possibility.

Some combination of the general insensitivity of fracture logging and effects of unloading on surface exposures seems to be the most likely explanation for the behavior of the fracture data. Certainly part of the reason the colonnade is indistinct is that, depending on how close the drill hole happens to be to a major colonnade fracture, the data will indicate either highly fractured or moderately fractured rock. Averaged out, these are not distinct from an entablature that is relatively unfractured compared to that in surface outcrop. Alternatively, an increase in undetected drilling-induced fractures in the colonnade relative to the entablature could produce a blurring of the distinction between the two.

\section{CONCLUSIONS AND RECOMMENDATIONS}

Intraf low structures in the Grande Ronde Basalt at Sentinel Gap are of three types:

1. Flows with stubby irreguiar columns that lack a well-developed entablature;

2. Flows consisting of multiple tiers of largely entablature-type columns; and,

3. Flows with a well-developed colonnade and entablature shnwing a distinct break between the two.

Petrographic textures of basalt correlate well with intraflow structures and can be used to define the position of the intraf low contact between entablature and colonnade from drill core samples. Because of this, tiered flows should be readily recognized in drill cores and flows with a poorly developed entablature should also be apparent. In addition, there is potential for using basalt textures for quantitatively estimating fracture abundance. 
These results suggest that future use of fracture logging for the purpose of determining intraflow structures will be of limited value and that the objectives of fracture logging existing core and possibly core currently being drilled need to be reexamined. On the other hand, the analysis of basalt textures, visa-vi intraflow structures, should be pursued in a quantitative way. Eventually, an understanding of the process by which intraflow structures are formed may be useful in predicting lateral changes in intraflow structures. Such predictive ability would be useful for both siting and constructing a repository.

\section{ACKNOWLEDGMENTS}

I thank Dr. C. W. Myers, and Messrs S. P. Riedel and R. K. Ledgerwood for critical reviews of the manuscript; Mr. R. W. Cross drafted the stratigraphic sections; Mr. R. D. Landon and Ms. M. G. Jones assisted with the field work and performed much of the tedious work of fracture logging--their help is gratefully acknowledged.

\section{BIBLIOGRAPHY}

Ames, L. L., 1978, Basalt-Waste Interactions: Fiscal Year 1978 Progress Report, RHO-BWI-C-27, Rockwe1] Hanford Operations, Richland, Washington.

Bentley, R. D., 1977, "Stratigraphy of the Yakima Basalts and Structural Evolution of the Yakima Ridges in the Western Columbia Plateau," in Brown, E. H., and Ellis, R. C., editors, Geological Excursions in the Pacific Northwest, Western Washington University Press, Bellingham, Washington, pp. 339-389.

Grolier, M. J., and Bingham, J. W., 1971, Geologic Map and Sections of Parts of Grant, Adams, and Franklin Counties, Washington, U. S. Geological Survey Miscellaneous Geologic Investigations Map I-589.

Grolier, M. J., and Bingham, J. W., 1978, "Geology of Parts of Grant, Adams, and Frank lin Counties, East-Central Washington," Washington State Department of Natural Resources Division of Geology and Earth Resources Bullet in Number 71, $91 \mathrm{p}$.

Holmgren, D. A., 1968, "Origin of Subhorizontal Platy Jointing in the Yakima Basalt," Northwest Science, 42, p. 35.

Iddings, J. P., 1909, Igneous Rocks, Wi ley, New York, New York.

Lofgren, G., 1974, "An Experimental Study of Plagioclase Crystal Morphology: Isothermal Crystallization," American Journal of Science, 274, pp. 243-273. 
Macken, J. H., 1961, "A Stratigraphic Section in the Yakima Basalt and Ellensburg Formation in South-Central Washington, "Washington Division of Mines and Geology Report of Investigation 19, $45 \mathrm{p}$.

Mallet, R., 1875, "Origin and Mechanism of Production of (or Prismatic Columnar) Structure of Basalt," Philosophy Magazine, 4, pp. 122-135 and 201-226.

Myers, C. W., 1973, Yakima Basalt Flows Near Vantage, and from Core Holes in the Pasco Basin, Washington, Ph.D. Thesis, University of California at Santa Cruz, Santa Cruz, California.

Peck, D. L., and Minakami, T., 1968, "The Formation of Columnar Joints in the Upper Part of Kilauean Lava Lakes, Hawaii," Geological Society of America Bulletin, 79, pp. 1151-1166.

Reide1, S. P., 1978, Geology of the Saddle Mountains Between Sentinel Gap and $119^{\circ} 31^{\prime}$ Longitude, RHO-BWI-LD-4, Rockwe11 Hanford Operations, Richland Washington.

Ryan, M. P., and Sammis, C. G., 1978, "Cyclic Fracture Mechanisms in Cooling Basalt," Geological Society of America Bulletin, 89, pp. 1295-1308.

Spry, A., 1962, "The Origin of Columnar Jointing, Particularly in Basalt Flows," Geological Society of Australia Journal, 8, pp. 191-216.

Swanson, D: A., 1967, "Yakima Basalt of Tieton River Area, South-Central Washington," Geological Society of America Bullet in, 78, pp. 1077-1110.

Taylor, T. L., 1976, The Basalt Stratigraphy and Structure of the Saddie Mountains of South-Central Washington, M. S. Thesis, Washington State University, Pullman, Washington, $116 \mathrm{p}$.

Tomkeieff, S. I., 1940, "Basalt Lavas of the Giant's Causeway, "Bulletin of Volcanology, 2 , pp. 89-146.

DISTRIBUTION

Number of

Copies

J. F. T. AGAPITO

1

CENTRAL WASHINGTON UNIVERSITY

Department of Geology

1

COLORADO SCHOOL OF MINES

1

J. W. CORWINE

GEOSCIENCE RESEARCH CONSULTANTS

J. G. Bond 
Distribution (continued)

Number of Copies

1

1

1

1

1

1

1

1

1

2

3

1

1

1

1

1

IDAHO BUREAU OF MINES AND GEOLOGY

M. M. Miller

OREGON STATE DEPARTMENT OF GEOLOGY AND MINERAL INDUSTRIES

J. D. Beaulieu

OREGON STATE UNIVERSITY

Department of Geology

PACIFIC NORTHWEST LABORATORY

J. R. Raymond

F. L. PARKER

I. REMSON

R. SCHNEIDER

G. SERVOS

U. S. BUREAU OF RECLAMATION Columbia Basin Project Geologist

U. S. DEPARTMENT OF ENERGY-COLUMBUS PROGRAM OFFICE

J. Neff

U. S. DEPARTMENT OF ENERGY-HEADQUARTERS

M. W. Frei

D. L. Vieth

U. S. DEPARTMENT OF ENERGY-RICHLAND OPERATIONS OFFICE

R. B. Goranson

D. J. Squires (2)

U. S. GEOLOGICAL SURVEY-WATER RESOURCES DIVISION

C. Collier

U. S. GEOLOGICAL SURVEY-WESTERN DIVISION

D. A. Swanson

UNIVERSITY.OF IDAHO

Department of Geology

UNIVERSITY OF WASHINGTON

Department of Geology

WASHINGTON PUBLIC POWER SUPPLY SYSTEM, INC.

D. D. Tillson 
Distribution (continued)

Number of Copies

1

1

1

i

1

39
WASHINGTON STATE DEPARTMENT OF ECOLOGY

P. M. Grimstad

WASHINGTON STATE DEPARTMENT OF NATURAL RESOURCES

V. E. Livingston

WASHINGTON STATE UNIVERSITY

Department of Geology

A. C. WATERS

H. C. WEISENECK

WESTERN WASHINGTON UNIVERSITY.

Department of Geology

ROCKWELL HANFORD OPERATIONS

H. Babad

D. J. Brown

D. J. Cockeram

T. A. Curran (5)

R. A. Deju (2)

R. C. Edwards

R. E. Gephart

R. J. Gimera

R. E. Isaacson

C. W. Myers

W. H. Price (5)

Basalt Waste Isolation Program Library (15) Document Control (4) 


\section{APPENDIX}

\section{PROCEDURE FOR COLLECTION OF FRACTURE DATA FROM SURFACE OUTCROPS}

Fractures were recorded from surface outcrops in two directions: a horizontal direction; and, a vertical direction. The purpose of the horizontal measurements was to accurately estimate the average column diameter in various parts of a flow that would allow consistent comparison from one flow to another. The purpose of the vertical measurements was to simulate the measurements made on drill core.

Horizontal measurements were made as follows:

1. Lay out 25 feet of tape across the outcrop;

2. Count and record major primary cooling joints (joints that define columns and separately count and record secondary fractures with in the 25-foot interval and describe);

3. Note and describe the following features:

0 . Fracture fillings, if any;

- Fracture curvature ( 1 to 10 scale);

0 Column perfection ( 1 to 10 scale);

o Preferred orientation (if one exists);

0 Measure amplitude and wavelength of pinch-and-swell features (if present).

Vertical measurements were made as follows:

1. Randomly select a starting point at the base of a flow;

2. From that starting point, measure an interval five feet in length and, along that interval, measure the position and orientation of each fracture intersecting the imaginary line between the beginning and end points of the interval; position can be simply read from a tape and the orientation measured with a Brunton Compass; note whether each fracture is primary (column-defining) or secondary (column-subdividing);

3. Subsequent intervals are to be established by projecting an imaginary horizontal line from the top of the previous interval to the next convenient position for the base of the next interval; its position should be as close as possible to the previous segment, but this will be determined by exposure and topográphy (see Figure A-1); 
4. For each interval, note and describe these general features:

o Fracture fillings, if any;

- Fracture curvature (1. to 10 scale);

- Column perfection (1 to 10 scale);

0 Preferred orientation (if any);

0 Measure amplitude and wavelength of pinch-and-swell features (if present);

5. Intervals should be concentrated in such a manner that they "continuously" sample as much of the flow as possible (see figure A-1). The upper parts of a flow will commonly be covered or otherwise inaccessible, but sections for measurement should be chosen such that the entablature--colonnade contact is tranversed. 


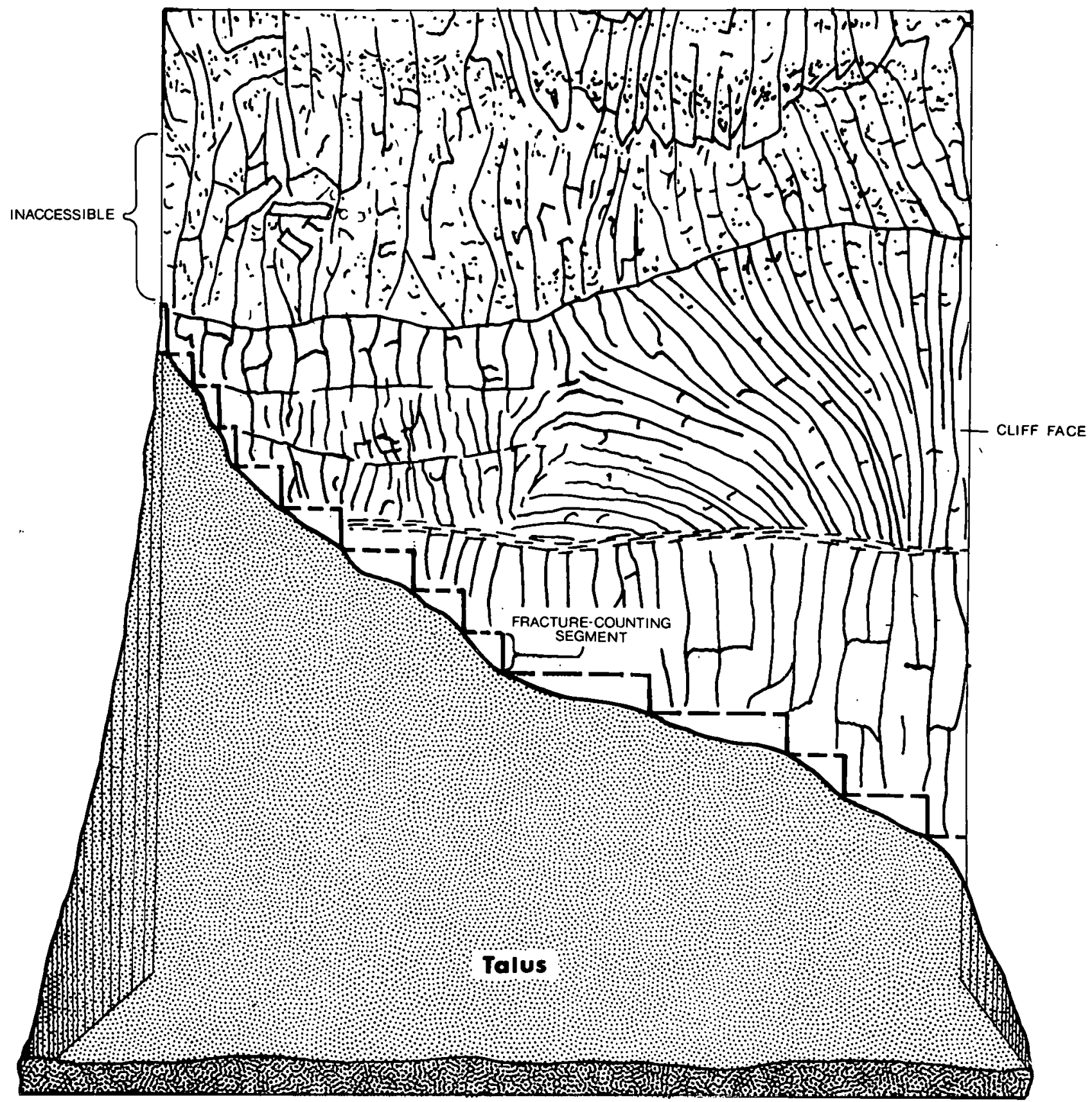

FIGURE A-1

SCHEMATIC REPRESENTATION OF CONCENTRATION OF VERTICAL FRACTURECOUNTING SEGMENTS

(Dashed lines connect the series of segments shown as solid lines.) 
SENTINEL BLUFFS STRATIGRAPHIC SECTION

SAIPLE NUMBER

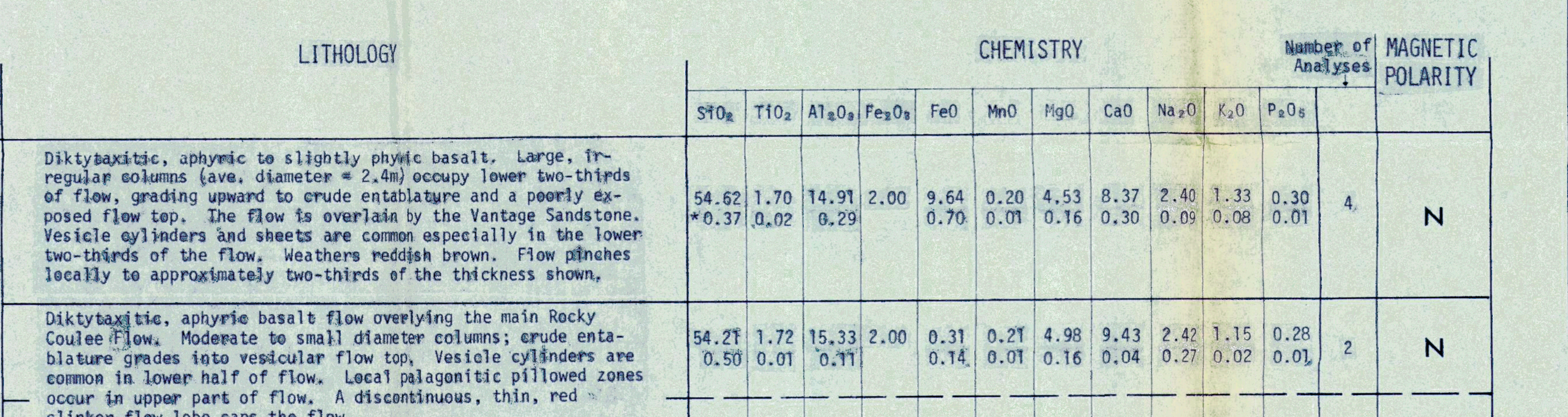

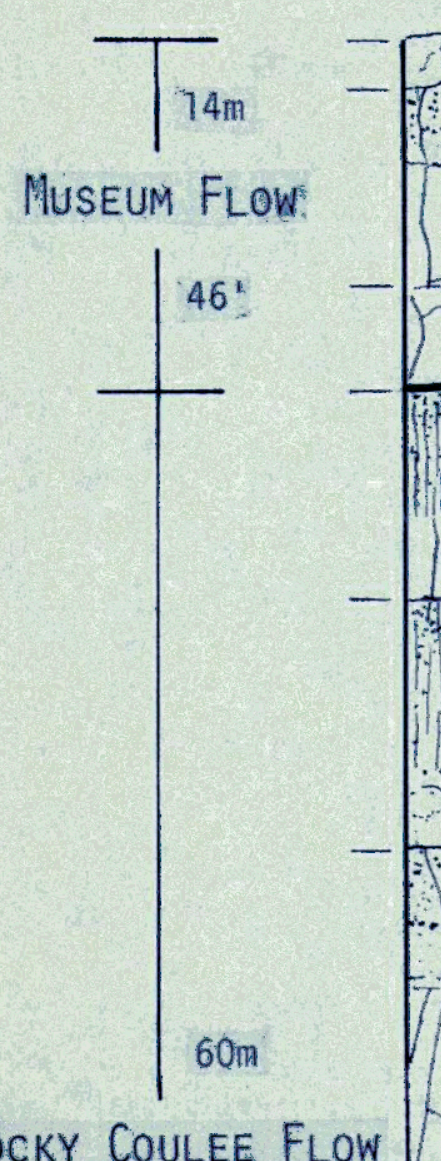

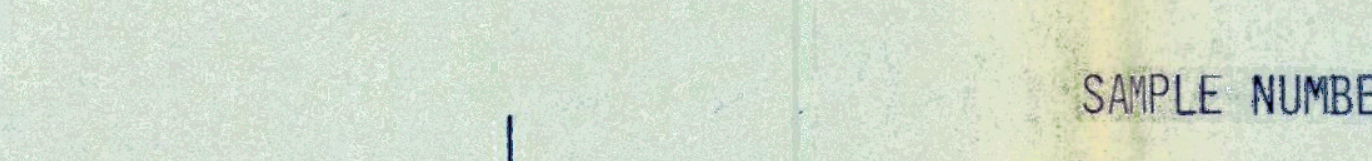

ER

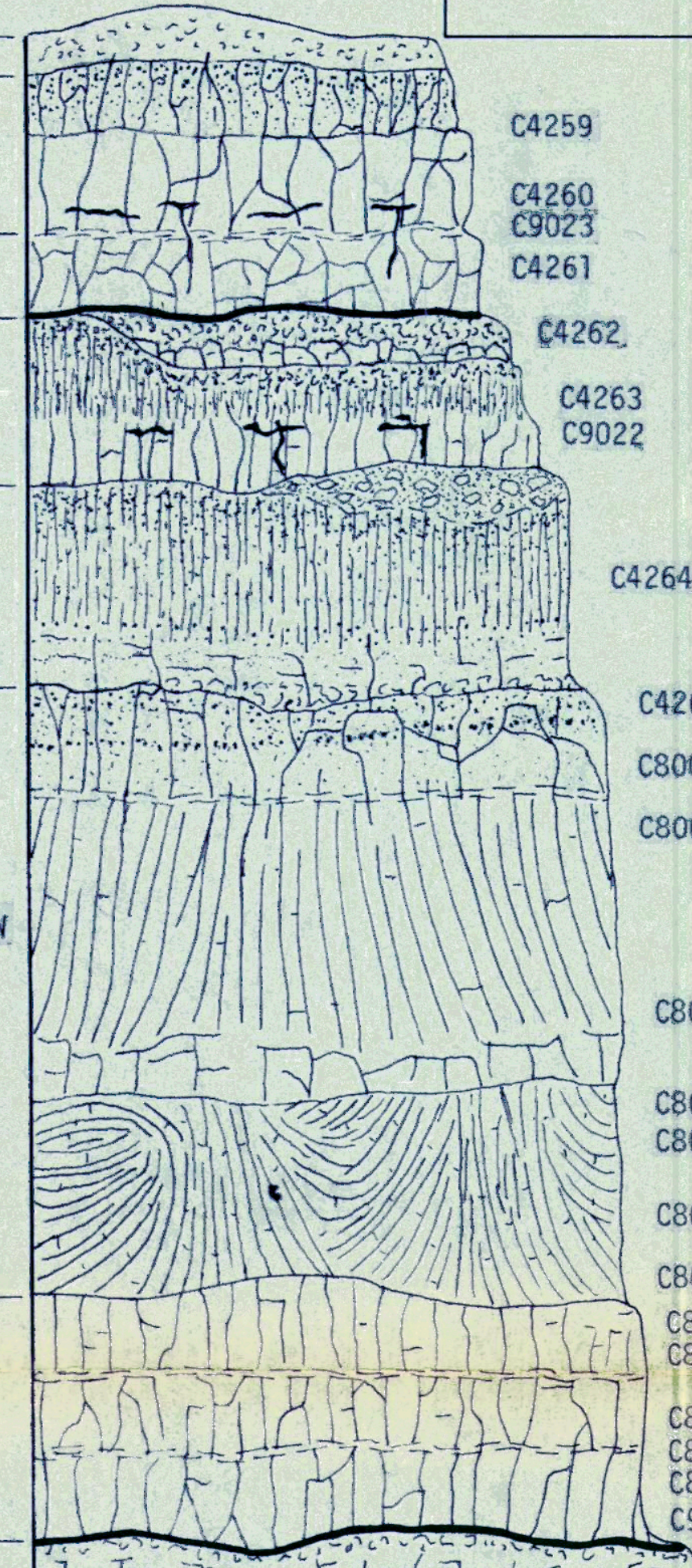

.

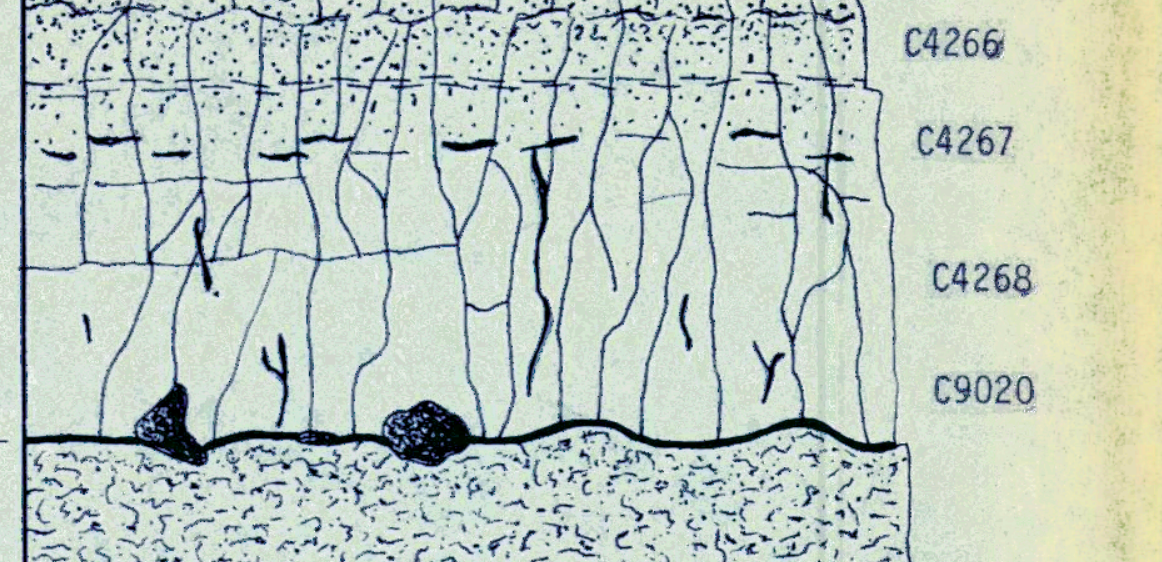

Fion

24.5n-
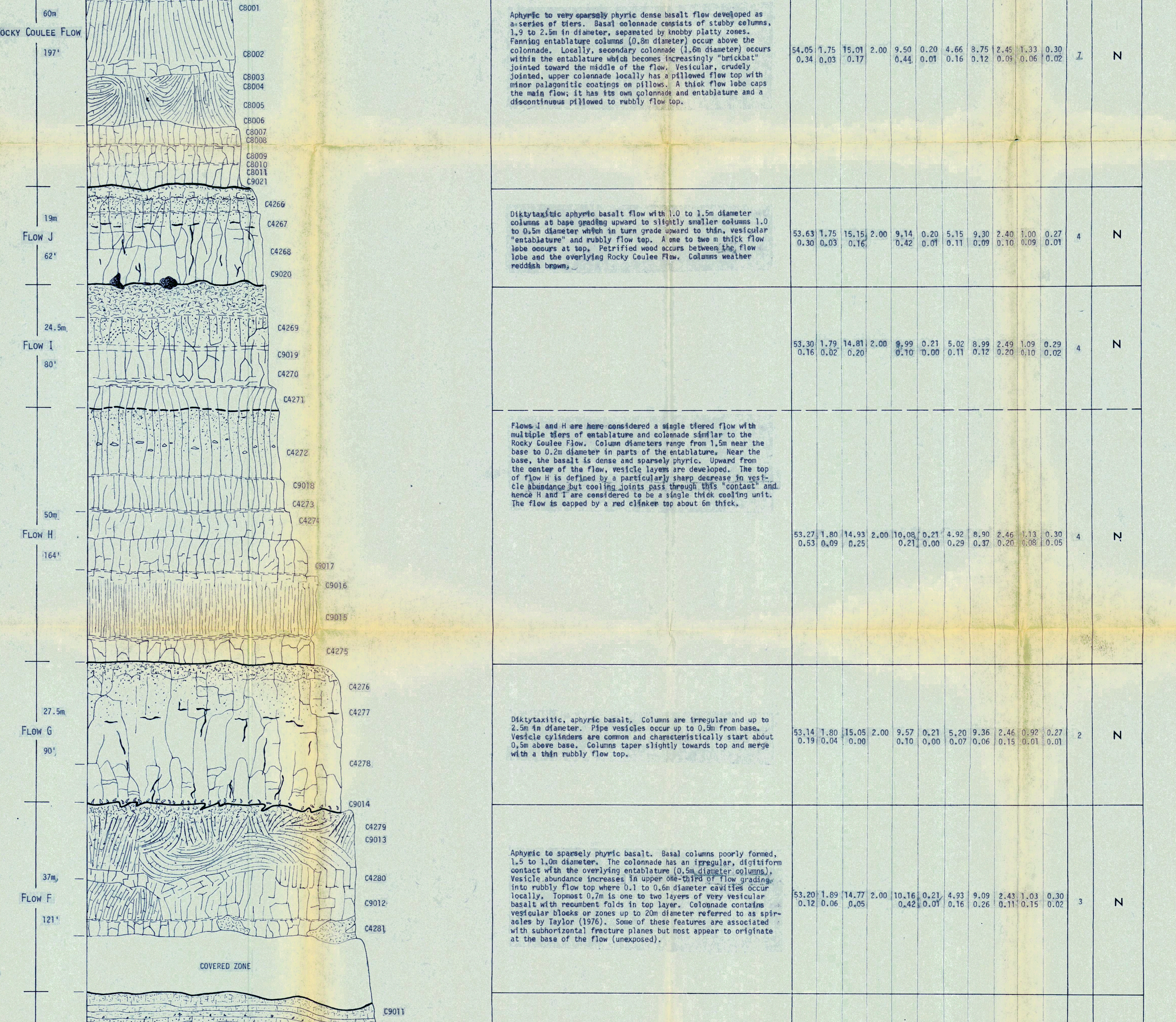

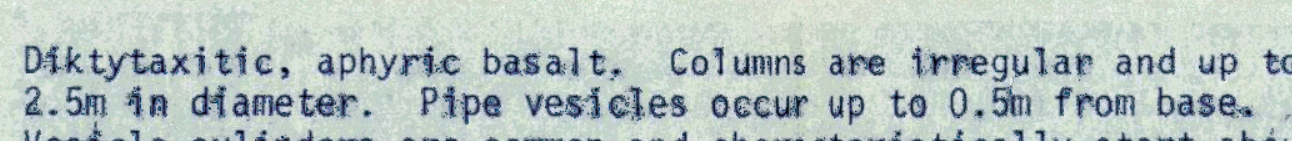

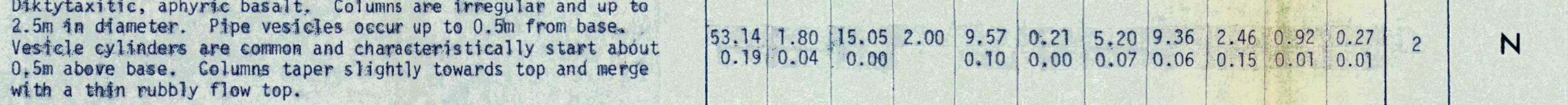

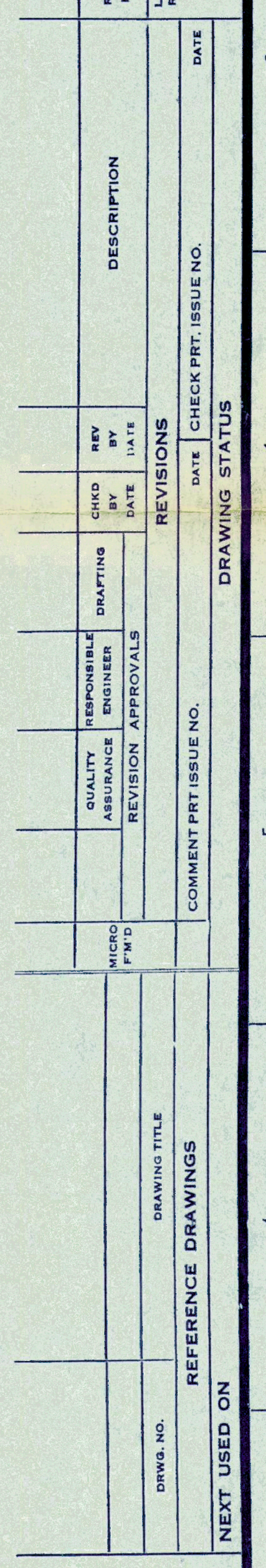

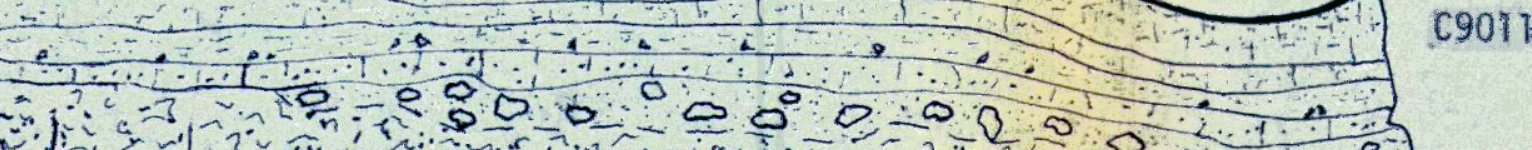
Th-1)

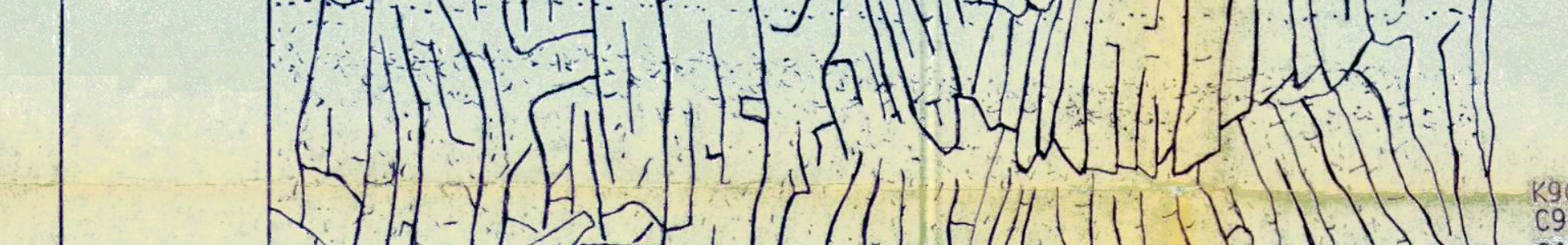

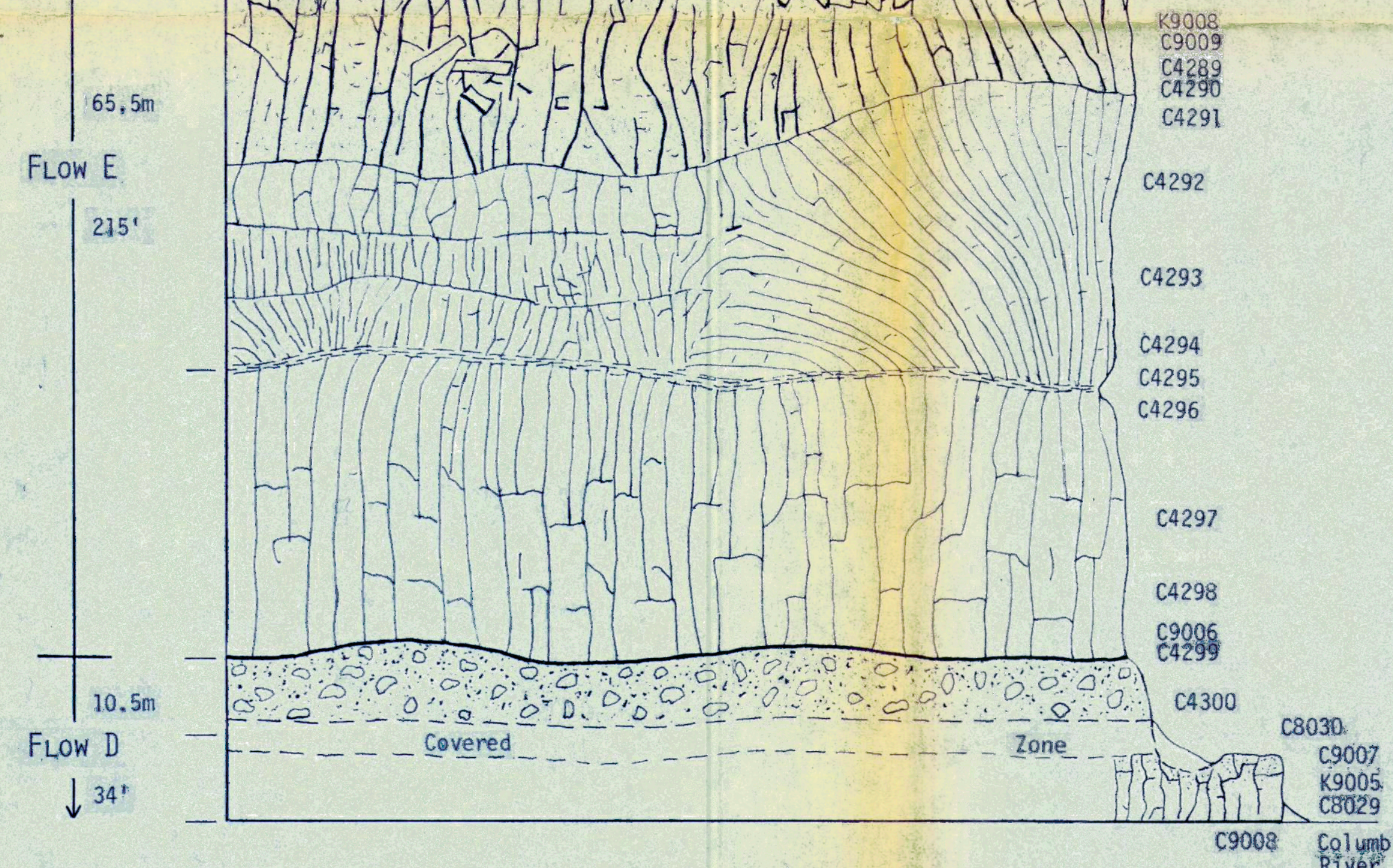

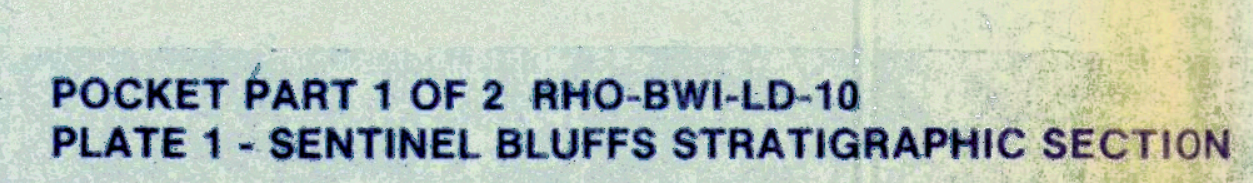

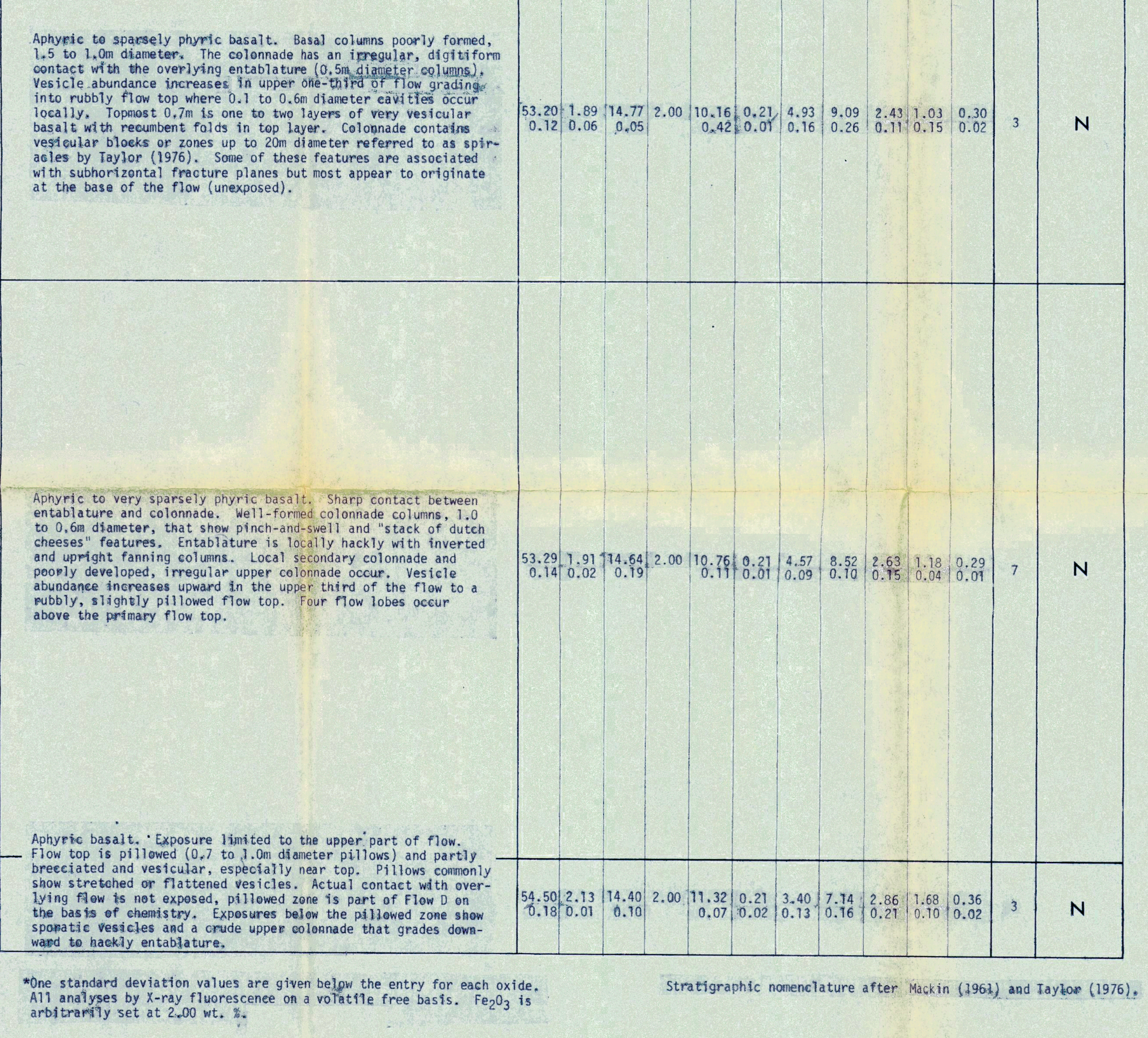


SCHWANA STRATIGRAPHIC SECTION
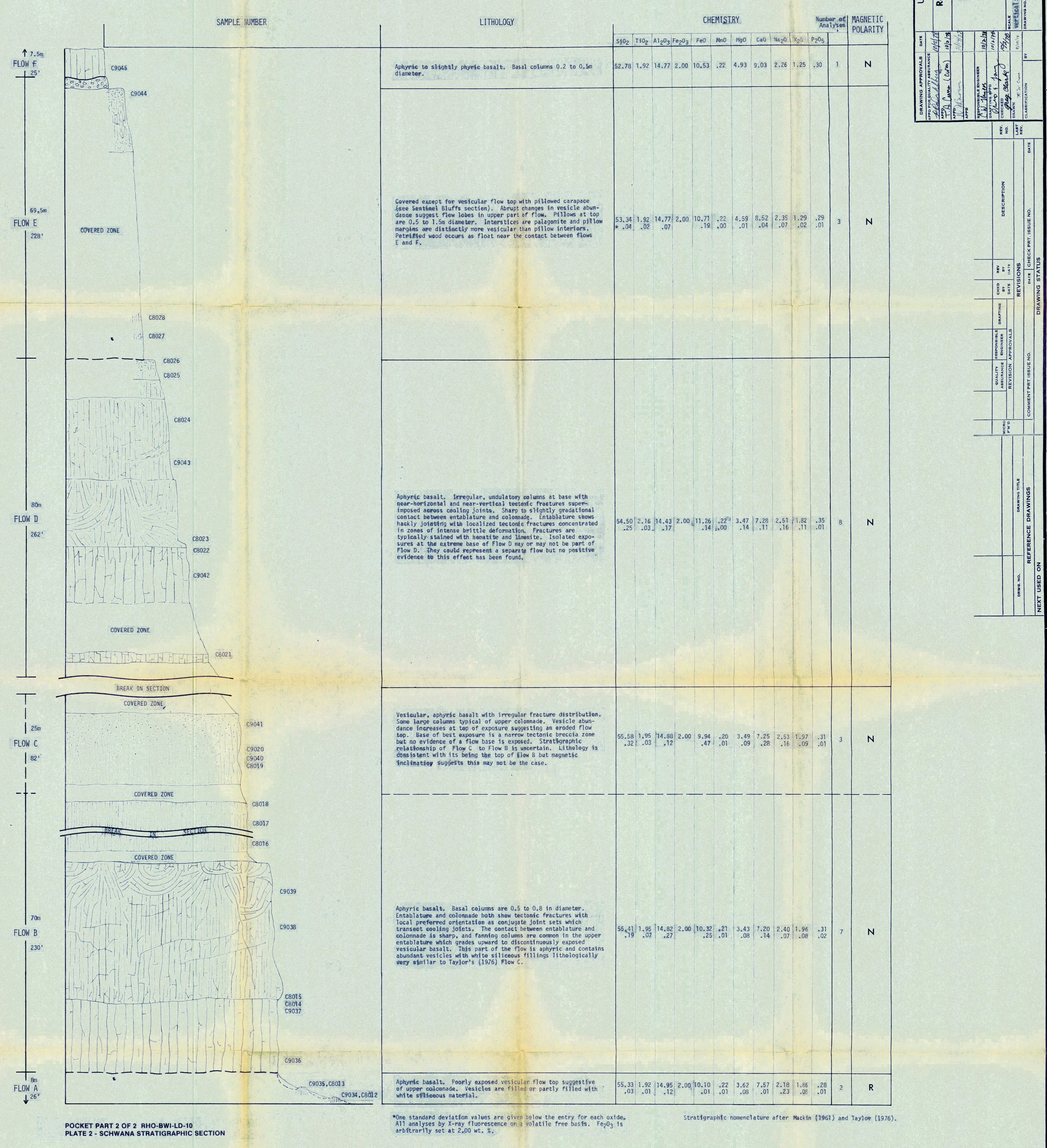
An

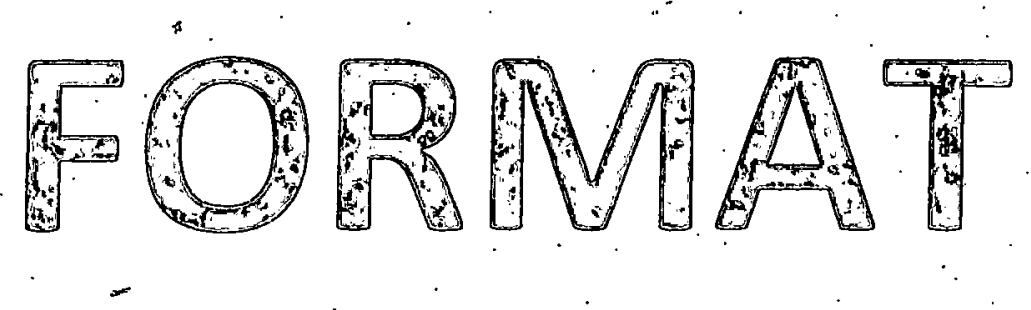

DOCH . 562625-1

BOX\#_2171730A

INITIAĹ

Aett

DATE $\quad 3 / 15 / 13$ 


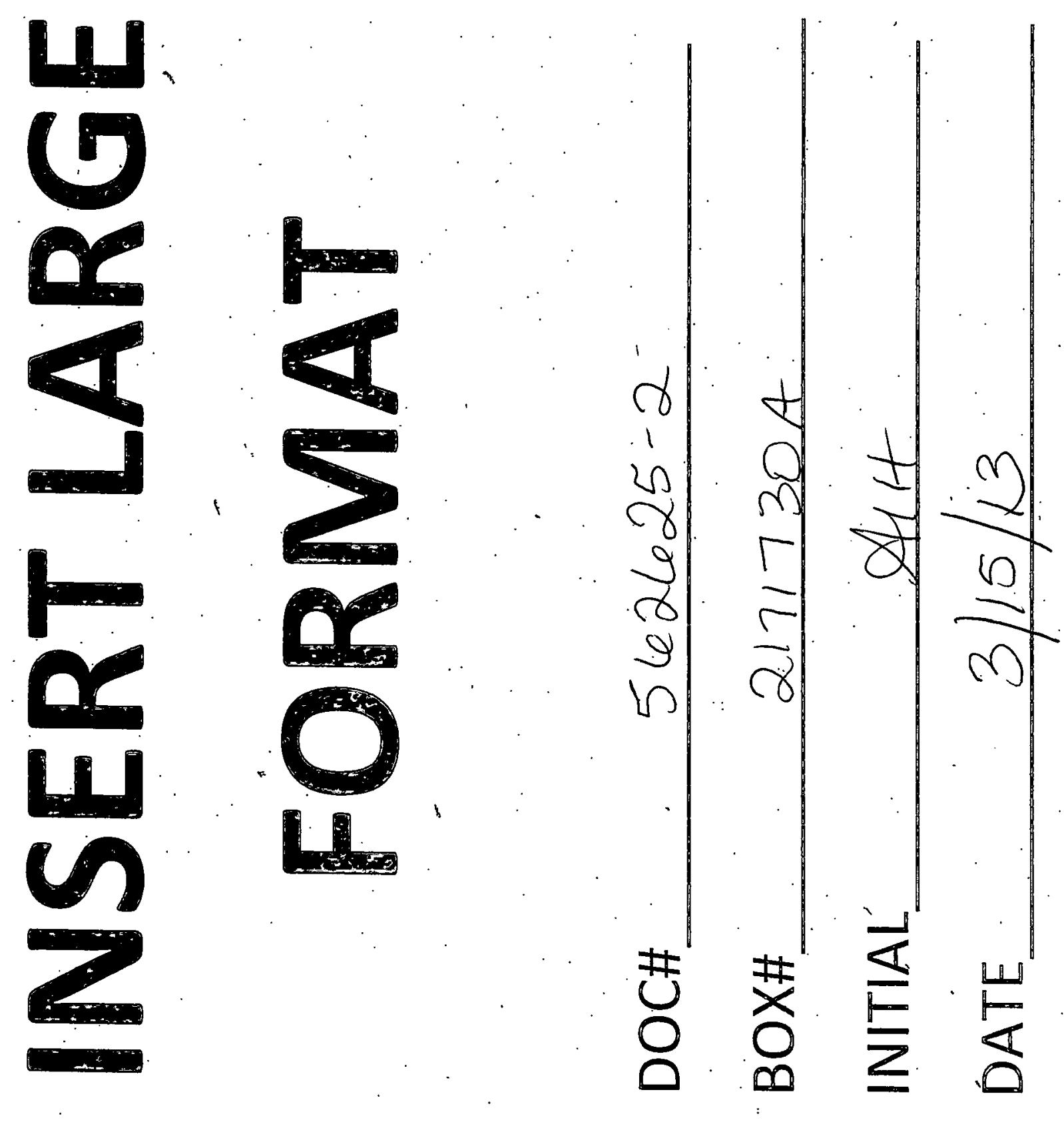

